FACULDADE DE FILOSOFIA, LETRAS E CIÊNCIAS HUMANAS DEPARTAMENTO DE CIÊNCIA POLÍTICA

RODRIGO MARTINS

O Processo Decisório na Assembleia Nacional

Constituinte de 1987-88: a Escolha do Sistema de

Governo

São Paulo

2013 
RODRIGO MARTINS

\section{O Processo Decisório na Assembleia Nacional \\ Constituinte de 1987-88: a Escolha do Sistema de \\ Governo}

Dissertação apresentada ao Programa de PósGraduação em Ciência Política da Faculdade de Filosofia, Letras e Ciências Humanas da Universidade de São Paulo, como requisito para a obtenção do título de Mestre em Ciência Política

Orientador: Prof. Dr. Rogério Bastos Arantes

São Paulo

2013 
Nome: Rodrigo Martins

Título: O Processo Decisório na Assembleia Nacional Constituinte de 1987-88: a

Escolha do Sistema de Governo

Dissertação apresentada ao Programa de PósGraduação em Ciência Política da Faculdade de Filosofia, Letras e Ciências Humanas da Universidade de São Paulo, como requisito para a obtenção do título de Mestre em Ciência Política

\section{Banca Examinadora}

Prof. Dr. Rogério Bastos Arantes (orientador)

Universidade de São Paulo Assinatura:

Prof. Dr.:

Instituição: Assinatura:

Prof. Dr.:

Instituição:

Assinatura:

Aprovado em: 


\section{Agradecimentos}

Gostaria de agradecer ao suporte institucional que o Departamento de Ciência Política oferece ao seu corpo discente, com a dedicação de professores, funcionários e alunos. Sem o apoio de todos não teria sido possível concluir este trabalho.

Dentre os professores, primeiramente agradeço ao meu orientador, Rogério Arantes, pela dedicação e paciência ao longo destes anos. Nossas discussões foram fundamentais, e suas sugestões sempre certeiras e iluminadoras contribuíram enormemente para o desenvolvimento desta dissertação. Agradeço também aos professores Cícero Araújo e Fernando Limongi, que despertaram meu interesse pela Assembleia Nacional Constituinte de 1987/88, o primeiro através da orientação ainda na graduação através do programa Ensinar com Pesquisa, e o segundo pela oportunidade dada em colaborar com a construção do banco de dados do CEBRAP com as votações das comissões da Constituinte. Também sou grato aos professores fizeram parte da banca de qualificação, Fernando Limongi e Marta Arretche, que deram importantes sugestões ao trabalho.

Não poderia deixar de agradecer os funcionários do departamento que sempre ajudam os alunos com suas dúvidas, problemas e urgências. Rai, Vasne, Leo e Ana Maria são as peças essenciais que mantém as engrenagens do DCP funcionando.

Muitas pessoas foram importante para tornar o dia-a-dia mais agradável. Aos colegas de curso, agradeço às discussões e enriquecimento de minha formação. Aos amigos de

república, agradeço aos momentos de descontração. À família agradeço o incentivo e apoio incondicionais. E à Marcela agradeço todo o amor, companheirismo e paciência nos vários momentos de stress.

Por fim ao CNPq pelo apoio financeiro para a realização desta pesquisa. 
Institutional designers always have some shared interest in the good performance of institutions and a partisan interest in the political advantage that institutions provide.

These two logics of institutional choice tend to coexist at different levels of constitutional design.

Negretto (2013) 


\section{Resumo}

\section{MARTINS, R. (2013). O Processo Decisório na Assembleia Nacional Constituinte}

de 1987-88: a Escolha do Sistema de Governo. Dissertação de Mestrado. Faculdade de Filosofia, Letras e Ciências Humanas, Universidade de São Paulo, São Paulo.

Mesmo após ter completado 25 anos, a Constituinte de 1987/88 suscitou até agora, no campo da Ciência Política, relativamente poucos trabalhos acadêmicos de fôlego. Apesar de alguns estudos evidenciarem a importância e centralidade do debate entre presidencialismo e parlamentarismo na Constituinte, nenhum deles se aprofundou no tema, evidenciando como se deu o processo decisório em torno da questão, quais grupos defenderam certas posições, quais eram seus interesses, quais propostas foram feitas e porque uma delas sagrou-se vitoriosa ao final.

Esta dissertação tem como objetivo o estudo do processo decisório da Assembleia Nacional Constituinte brasileira de 1987/1988, no que diz respeito à escolha do sistema de governo, questão central do debate institucional na época. A pretensão é analisar quais as linhas de força que, ao longo do processo constituinte, manifestaram-se a esse respeito, e quais os meios que foram vislumbrados para torná-los efetivos. Para isso, tornase necessário identificar e analisar os atores relevantes, a natureza de suas preferências políticas, a interação desenvolvida e as opções por eles gestadas e postas em prática, em meio a um processo deliberativo de tipo especial, aquele que geralmente marca as assembleias constituintes.

Palavras-chave: Assembleia Nacional Constituinte, sistema de governo, escolha institicional. 


\begin{abstract}
MARTINS, R. (2013). The Decision Making Process in the National Constituent Assembly of 1987-88 : the Choice of the Government System. MA dissertation. Faculty of Philosophy, Letters and Human Sciences, University of São Paulo, São Paulo

Even after 25 years, the Brazilian Constituent Assembly of 1987-88, as of late, was the object of relatively few important academic studies in the field of Political Science. Although some studies demonstrate the importance and centrality of the debate between presidentialism and parliamentarism in the Assembly, none of them has studied the topic in depth, showing how was the decision making process around the issue, which groups advocated certain positions, which were their interests, which proposed were made and the reason why one of them was victorious at the end.

This work's goal is the study of the decision-making process of the Brazilian National Constituent Assembly of 1987-1988, with respect to the choice of the government system, the central issue of the institutional debate at the time. The intention is to analyze which lines of force emerged in this regard along the constituent process, and what means were envisioned to make them effective. For this, it is necessary to identify and analyze the relevant actors, the nature of their political preferences, how the interaction between actors took place and the developed and implemented options in the midst of a deliberative process of a special kind, one that often marks the constituent assemblies.
\end{abstract}

Keywords: National Constituent Assembly, government system, institutional choice. 


\section{Lista de Figuras}

1 Dispersão ideológica entre membros do plenário - Partidos . . . . . . . . . 82

2 Dispersão ideológica entre membros do plenário - Centrão . . . . . . . . . . 83

3 Dispersão ideológica entre membros do plenário - Emenda Humberto Lucena 84

4 Boxplot - Dispersão ideológica . . . . . . . . . . . . . 85

5 Boxplot - Dispersão ideológica - Partidos . . . . . . . . . . . . . . . 85

6 Boxplot - Dispersão ideológica - Centrão . . . . . . . . . . . . . . 86

7 Boxplot - Dispersão ideológica - Sistema de governo . . . . . . . . . . . . 87 


\section{Lista de Tabelas}

1 Pesquisas de opinião - Datafolha . . . . . . . . . . . . . . . . . . 59

2 Pesquisas de opinião - Datafolha - Partidos . . . . . . . . . . . . . 61

3 Número de manifestações . . . . . . . . . . . . . . . . . . . . . . . . . . 62

4 Número de manifestações por partido . . . . . . . . . . . . . . . . . . 62

5 Temas das manifestações em plenário: . . . . . . . . . . . . . . . . . . . . 64

6 Resultado da votação da Emenda Humberto Lucena . . . . . . . . . . . . . 76

7 Votação da Emenda Humberto Lucena por partido . . . . . . . . . . . . . 77

8 Votação da Emenda Humberto Lucena por nota do DIAP . . . . . . . . . . 77

9 Votação da Emenda Humberto Lucena pelo Centrão . . . . . . . . . . . . . 79

10 Votação da Emenda Humberto Lucena por grupos suprapartidários . . . 80

11 Votação da Emenda Humberto Lucena por partidos do regime militar . . . 81

12 Concessões e votação na Emenda Humberto Lucena . . . . . . . . . . . . . 89

13 Governismo e votação na Emenda Humberto Lucena ......... 90

14 Governismo-PMDB ........................ 91

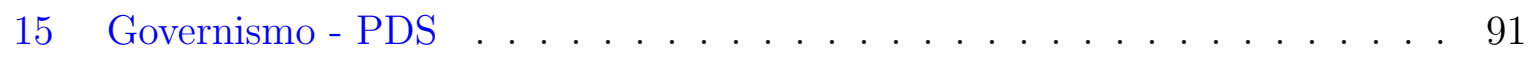

16 Governismo - PTB . . . . . . . . . . . . . . . . . 92 


\section{Lista de Siglas e Abreviaturas}

ARENA Aliança Renovadora Nacional

DIAP Departamento Intersindical de Assessoria Parlamentar

EHL Emenda Humberto Lucena

PC do B Partido Comunista do Brasil

PCB Partido Comunista Brasileiro

PDC Partido Democrata Cristão

PDS Partido Democrático Social

PDT Partido Democrático Trabalhista

PFL Partido da Frente Liberal

PL Partido Liberal

PMB Partido Municipalista Brasileiro

PMDB Partido do Movimento Democrático Brasileiro

PRN Partido da Reconstrução Nacional

PSB Partido Socialista Brasileiro

PSD Partido Social Democrático

PSDB Partido da Social Democracia Brasileira

PSP Partido Social Progressista

PT Partido dos Trabalhadores

PTB Partido Trabalhista Brasileiro

PTR Partido Trabalhista Reformador 
UBE União Brasileira de Empresários

UDN União Democrática Nacional

UDR União Democrática Ruralista 


\section{Sumário}

$\begin{array}{ll}\text { Introdução } & 13\end{array}$

Capítulo 1 - O Presidencialismo, Seus Críticos e Defensores 22

Seção I - Os críticos . . . . . . . . . . . . . . . . . . . . . 24

Seção II - Os defensores . . . . . . . . . . . . . . . . . . . . . 33

Seção III - O presidencialismo de coalizão revisitado . . . . . . . . . . . . . . . 38

Capítulo 2 - Estudos sobre a constituinte e a escolha do sistema de governo 44

Seção I - As mudanças institucionais de 1961/63 . . . . . . . . . . . . . . . . 50

Seção II - A Escolha do Sistema de Governo em 1987/88 à Luz de 1961/63 . . 54

Capítulo 3 - O Posicionamento dos Constituintes em Relação ao Sistema $\begin{array}{ll}\text { de Governo } & 57\end{array}$

Seção I - Análise dos Discursos . . . . . . . . . . . . . . . . . . . . 60

Seção II - Votação da Emenda Humberto Lucena . . . . . . . . . . . . . . . . . 76

Seção III - A Divisão da Constituinte Frente em Relação ao Sistema de Governo 87

$\begin{array}{ll}\text { Conclusão } & 94\end{array}$ 


\section{Introdução}

No livro "Democracia e Mercado", Adam Przeworski definiu a democracia como "um sistema de incerteza organizada" (1994). A democracia seria um sistema de incerteza porque, sob regras democráticas, os resultados da disputa política não são conhecidos previamente por nenhuma das forças em disputa. E é justamente por sua aparência de incerteza que a democracia confere a todos uma oportunidade de lutar por seus interesses, pois, se os resultados fossem pré-determinados, não haveria razão para que os atores participassem do jogo democrático.

Esse sistema de incerteza tem, no entanto, outra característica fundamental: trata-se de um sistema organizado no qual a interação entre os atores políticos é mediada por uma estrutura institucional, composta de regras e procedimentos estabelecidos e conhecidos. Segundo Przeworski, "o passo decisivo em direção à democracia é dado pela transferência do poder de um grupo de pessoas para um conjunto de regras" (1994, p. 31). A organização da incerteza em regimes democráticos tem na Constituição sua referência maior. Trata-se da lei fundamental, que alicerça e que delimita todo o conjunto de normas e de práticas jurídicas do País.

O processo de elaboração de uma Constituição pode ser entendido como um momento fundacional que se torna uma referência para a sociedade. Dependendo da forma como ocorrer, pode se tornar um dos momentos mais ricos e intensos da trajetória política de um país. Nele se busca um compromisso entre as elites, os cidadãos e os grupos sociais em torno de soluções para os dissensos previamente existentes, por meio da construção de regras comuns e compartilhadas. A deliberação constituinte é chamada para fixar os princípios básicos do funcionamento das instituições e da sociedade, orientando a política ordinária e o desempenho econômico de longo prazo (Elster, 1994). Nesse momento, os atores políticos, sem abandonar suas posições político-ideológicas peculiares, expressam uma visão de futuro para sua sociedade, estipulando, por meio de mecanismos legais, caminhos a serem percorridos e metas a serem alcançadas.

No campo acadêmico discute-se, há algum tempo, se momentos constituintes seriam marcados por maior neutralidade dos atores políticos, os quais estariam empenhados na 
definição de objetivos de mais longo prazo (Elster, 1993) ou se a elaboração da Constituição seria caracterizada por um forte conflito de interesses no qual cada ator saberia, não sem algum grau de incerteza, quais arranjos institucionais seriam os mais adequados à consecução de seus objetivos e mais coerentes com seus interesses (Przeworski, 1994).

O processo constituinte brasileiro pode ser analisado a partir de ambas as perspectivas. Admite-se que os atores relevantes nele envolvidos, ou seja, as lideranças políticas, os partidos e os grupos sociais que influenciaram a elaboração da Constituição, possuíam interesses e reivindicações claras, tanto do ponto de vista procedimental quanto substantivo, e se empenharam para incluí-los em seu escopo (Souza, 2003; Nobre, 2008). Pressupõe também que os constituintes, ao pensarem os principais aspectos do arranjo institucional que seria inaugurado em 1988, em boa medida tinham consciência de seus prováveis efeitos. Isso, no entanto, não significa dizer que os atores políticos não tivessem compromisso com certos princípios. De fato, durante o processo constituinte brasileiro, foi possível verificar o debate de ideias em torno de vários aspectos do arranjo político futuro e viu-se um real compromisso com o aperfeiçoamento institucional (Souza, 2003).

Dada a natureza do texto constitucional, caracterizado pela generalidade e pela orientação para um futuro indefinido, é comum advogar o uso da razão pelos constituintes que deveriam deliberar com a maior imparcialidade e independência aos interesses contingentes. No entanto, a deliberação pode ser influenciada por condições empiricamente não favoráveis, como a polarização das partes ou um andamento do processo deliberativo caracterizado pela radicalização dos comportamentos.

Elster (1998) expõe sete proposições que caracterizariam um processo constituinte ideal: 1) Para reduzir a abrangência de interesses institucionais, as constituições devem ser escritas por assembleias convocadas especialmente para esse fim, e não por corpos de representantes que trabalham como legisladores normais. As legislaturas que não são eleitas para esse fim não devem ocupar lugar central do processo de ratificação do texto constitucional. 2) Instituições e atores cujos comportamentos serão regulados pela Constituição não poderiam participar do processo constitucional. 3) O processo constitucional deve conter elementos tanto de segredo (discussão em comissões) quanto de publicidade 
(discussões no plenário da assembleia). Quando há segredo total, interesses partidários e conchavos dão o tom das discussões, enquanto a publicidade total encoraja exageros retóricos. Em contraste, o segredo permite discussões sérias, enquanto a publicidade assegura que qualquer acordo proposto é capaz de ser firmado de fato. 4) As eleições para a assembleia constituinte devem ser realizadas por meio do sistema proporcional e não o majoritário. 5) Para diminuir a possibilidade de ameaças e tentativas de influenciar o processo deliberativo, por meio de manifestações de massa, a assembleia constituinte não deve se reunir na capital do país ou em uma cidade grande. Também não pode-se permitir que as Forças Armadas se reúnam nas proximidades da assembleia 6) A constituição deverá se sujeitar à ratificação popular por meio de referendo. 7) A fim de eliminar interesses privados de curto prazo ou interesses partidários, a assembleia constitucional poderia impor a regra de que a Constituição não deve entrar em vigor até alguns anos depois de ser votada pelos constituintes. Esse procedimento criaria um "véu de ignorância" artificial, forçando cada representante a se colocar no lugar de todos os cidadãos.

Em termos gerais, o desenho ótimo de constituinte proposto por Elster visa equilibrar os elementos do interesse, da paixão e da razão no processo de elaboração constitucional. Sem descartar completamente os dois primeiros, mas procurando minimizar sua influência, a proposta global de Elster tem em mente maximizar o que ele chama de "epistemic quality of decisions" na medida em que fosse capaz de reduzir "the scope of fear, anger, malice, vanity and other emotions that may interfere with the quality of the arguments" (2008, p. 5).

A Assembleia Nacional Constituinte de 1987-1988 satisfez apenas dois destes sete pontos propostos por Elster (eleições proporcionais para a constituição da assembleia e elementos de segredo e publicidade no processo deliberativo). De fato, veremos nesse trabalho como as demais características de nossa Assembleia conferiram grande permeabilidade a interesses de diversas origens e pressão constante sobre os trabalhos constituintes. Se o modelo de Elster previa na verdade duas grandes fases - uma na qual os constituintes trabalhariam mais reservadamente, longe das pressões externas, e outra na qual o resultado de seus esforços seria submetido a referendum popular - a experiência brasileira não 
contou com um espaço protegido de deliberação na primeira fase tampouco submeteu o resultado final ao escrutínio popular. De qualquer maneira, o mundo real dos processos constituintes dista fortemente da idealização proposta por Elster. Levantamento feito por Ginsburg, Elkins e Blount (2009) revelou uma grande diversidade de fórmulas e modos de elaboração constitucional, sendo a Assembleia Constituinte exclusiva apenas a terceira delas, responsável apenas por $13 \%$ dentre os 460 casos examinados. A fórmula adotada no Brasil de 1987-88 (Congresso Constituinte) é de fato a modal, mas essa representa apenas 19\% do total analisado pelos autores (Ginsburg, Elkins e Blount, 2009).

Elaborar novas Constituições pode resultar em profundas manobras e negociações políticas e é também quando clivagens e consensos se tornam mais visíveis (Souza, 2001). Compreender como os constituintes agiram frente a tais conflitos pode contribuir para o nosso conhecimento sobre questões que ganharam importância no processo constituinte. Para aprofundar esse conhecimento, deveríamos procurar responder às seguintes questões formuladas por Elster (1993): como foi convocada a Constituinte? Como foram elaboradas suas normas internas? Qual o papel de interesses individuais e coletivos na elaboração da Constituição? Qual a importância de influências extraconstitucionais e seus interesses no processo Constituinte?

As arenas decisórias democráticas são abertas a estímulos e pressões de fatores internos e externos. Isso quer dizer que os atores políticos têm que lidar com fatores intrínsecos do processo deliberativo — regras, indicação de líderes, posicionamento do partido — e fatores que são exógenos a esses processos — pressão de outros atores institucionais paralelos à Assembleia, como Presidentes, Militares e outros. Dessa forma, além de lidar com seus interesses, preferências ou princípios, os parlamentares estão sujeitos a organizar seus posicionamentos pessoais, definir aqueles que consideraria como os principais e lidar com as pressões advindas de vários setores. Em constituintes, assim como foi no caso brasileiro, a mobilização de interesses tende a ser mais intensa, pois a Carta produzida baliza um futuro indefinido e representa um momento decisivo para todos os segmentos da sociedade.

Investigar como se deram os debates, embates e o jogo político em torno do sistema 
de governo se torna relevante devido à sua centralidade e importância no contexto da Constituinte. Na definição de uma questão como essa é evidente a presença de interesses de curto prazo, quando não imediatos. Mas também existe um caráter normativo nos debates, que mobilizam conviç̧ões e crenças sobre forma de governo. Tornam-se latentes não só os interesses parlamentares, mas também de forças externas que acabaram interferindo fortemente no andamento dos trabalhos, como a pressão exercida pelo então presidente Sarney e os militares.

A Assembleia Nacional Constituinte pode ser compreendida como um evento de fundamental importância pois por meio dela o país se abriu à possibilidade de uma refundação institucional. Contextos como esse, que levam à rediscussão sobre nossas instituições políticas, e se mostram abertos a quaisquer reformas, constituem um interessante caso para fazer análises diversas utilizando-se as teorias de mudança institucional. Todavia, um aspecto interessante do presente trabalho é que, em vez de analisarmos um caso em que foi decidida uma mudança institucional, estaremos diante de um processo que levou a uma não-mudança - a do sistema de governo - apesar das fortes expectativas no período de que isso ocorreria. Analisar um momento em que era possível fazer uma mudança institucional mesmo quando ela não ocorreu também pode contribuir para uma elaboração teórica da escolha institucional.

Com o estudo do processo decisório sobre o sistema de governo na Assembleia Nacional Constituinte é possível explorar pontos a respeito do neoinstitucionalismo e a teoria da escolha racional, em relação a suas explicações para mudanças institucionais e formulação de preferências de atores políticos. Compreender a decisão dos constituintes em relação ao sistema de governo exige que levemos em consideração a forma como se estruturou a Assembleia Nacional Constituinte institucionalmente, seu contexto histórico e político, e como esses fatores influenciaram a ação dos agentes, suas preferências, suas ideias e estratégias.

Hoje, pode-se dizer que o grau de sucesso de uma teoria da mudança institucional depende de sua habilidade em integrar ambas as teorias, a escolha racional e o neoinstitucionalismo. Agentes, sua racionalidade e as opções de mudança institucional dependem 
do contexto e do processo histórico em que se encontram. Modelos de explicação sobre mudanças institucionais não podem se basear inteiramente no nível analítico da agência. A racionalidade deve ser institucionalmente construída pelos agentes. Tentar explicar a mudança institucional com base em modelos de racionalidade, associados a elementos relacionados ao contexto, processos históricos e as ações dos agentes tem sido o grande desafio. Compreender como agentes adotam comportamentos e estratégias que podem provocar mudanças, em quais condições podem produzir reflexivamente tais processos, como forjam interesses, identidades e representações são questões cruciais nesse campo de análise. Inseridas no contexto, a ideia é que preferências, escolhas e ações estratégicas conformam as possibilidades de mudanças.

O neoinstitucionalismo busca compreender como instituições surgem, evoluem e mudam (Hall e Taylor, 1996). Porém muitos autores afirmam que a questão da mudança institucional ainda é problemática e carece de teorias consistentes. Críticas recentes afirmam que o neoinstitucionalismo põe em evidência fatores internos às instituições para explicar a mudança, apesar de não deixar claro quais causas e mecanismos institucionais as provocam. Tais fatores internos provocariam mudanças pequenas, graduais, incrementais. Uma vez que atores políticos se adaptam à ordem institucional vigente, aprendem como agir e obter sucesso eleitoral, a mudança seria rara pois o custo de mudar uma instituição, mesmo que seja insatisfatória, seria menor do que criar outro desenho institucional (Pierson, 2004).

Fatores exógenos só influenciariam mudanças institucionais quando estas fossem drásticas e seriam feitas apenas em momentos críticos, nos quais haveria uma alteração na relação entre estrutura e agência. Em momentos de estabilidade, a estrutura prevaleceria sobre os agentes, e em períodos de conjuntura crítica a agência prevaleceria sobre os elementos da estrutura, fazendo com que agentes tenham poder de promover mudanças. Tal fato seria possível pois momentos críticos reduziriam ou eliminariam os custos associados à mudança institucional. Ainda assim, haveria uma lacuna em especificar quais condições provocariam um momento crítico e como ele realmente afeta o processo de mudança institucional. 
Uma vantagem do neoinstitucionalismo, mais especificamente o neoinstitucionalismo histórico, é que este considera a formação de preferências dos atores como endógeno ao processo político, podendo ser alteradas com o decorrer do tempo devido a fatores internos ao sistema. Assim, as preferências são originadas como causas de processos históricos, e induzidas por circunstâncias estratégicas através da interação entre atores pertencentes a certas instituições e processos sociais. Essa interação influenciaria agentes a terem uma preferência específica.

A teoria da escolha racional, ao contrário, assume que as preferências são fixas e determinadas exogenamente às instituições. Assim, de acordo com esta perspectiva, as mudanças institucionais não poderiam ser causadas por fatores endógenos. Para esta literatura, é importante fazer uma diferenciação entre preferências (de primeira ordem) e estratégias (de segunda ordem). Estratégias seriam atitudes e escolhas (formadas endogenamente) que ajudariam os agentes a alcançar suas preferências (exógenas e estáveis). Porém a conexão entre essas duas ordens de preferência é obscura. Afinal, nem toda escolha institucional necessariamente é estratégica, podendo ser feita baseada em outros critérios.

Parte da literatura neonstitucionalista tem levantado a questão de como ideias podem ser um aspecto de interessante análise nos estudos sobre mudança institucional (Hall e Taylor, 1996; Beland e Cox, 2011; Schmidt, 2010), e como elas podem estar relacionadas com o contexto social, econômico e histórico. Esse seria um novo fator para se pensar no papel da agência, bem como sua relação com a estrutura. Assim, um modelo que compreende como as tensões entre instituições e ideias podem gerar uma reformulação de incentivos e oportunidades estratégicas a atores políticos pode colaborar para uma melhor compreensão sobre mudanças institucionais. Baseado nisso, também seria construtivo analisar como os agentes formulam e alteram seus interesses e estratégias de ação. As ideias também podem ter papel central para entender como estas promovem um conflito que pode levar ou não a uma mudança institucional, e como o conflito de ideias pode gerar uma competição no processo de elaboração institucional. Mais interessante ainda é analisar como interesses divergentes ou contraditórios acabam por compartilhar as mesmas 
ideias.

Aqui tendemos a assumir o posicionamento de Elster (1983), quando se volta para discutir a intencionalidade como forma de explicação para os fenômenos sociais, chamando atenção para as potencialidades do individualismo metodológico. Para o autor, ainda que a socialização tenha alguma função na formação de crenças e preferências dos indivíduos, estes não seriam meros suportes passivos destas crenças e preferências, mas sim sujeitos autônomos que agiriam de acordo com cálculos de tipo racional considerando perdas e ganhos, cálculos estes que explicariam os fenômenos sociais, ou ao menos alguns destes.

Quatro hipóteses derivadas do neoinstitucionalismo e da teoria da escolha racional são frequentemente utilizadas pela literatura para explicar mudanças constitucionais: o legado histórico, a imparcialidade, o cálculo estratégico e a difusão (Negretto, 2009, p. 121). No presente trabalho, apenas a quarta hipótese não será abordada para o caso estudado. A primeira delas postula que os elaboradores da nova Constituição são influenciados por forças precedentes. Instituições estruturariam o processo de mudança de tal forma que apenas mudanças marginais ocorreriam, enquanto as regras básicas permaneceriam inalteradas. Essa hipótese seria consistente com o fato de que o Brasil sempre manteve o presidencialismo em seus diversos regimes pós-Império, mesmo tendo diversas oportunidades para fazer alterações.

Outra hipótese seria a da imparcialidade, pela qual os atores políticos escolheriam regras constitucionais baseados em benefícios coletivos, como governabilidade e legitimidade. Esta interpretação se baseia empiricamente no fato de que os atores políticos que participam do processo de elaboração constitucional manifestam suas preferencias institucionais em termos imparciais, usando argumentos normativos. No entanto algumas críticas podem ser dirigidas a essa vertente no sentido de que atores políticos frequentemente usam argumentos imparciais estrategicamente para defenderem interesses particulares ou partidários.

A terceira hipótese é baseada no interesse próprio e partidário. Nesta perspectiva, os atores políticos defenderiam certo desenho institucional orientados em cálculos estratégicos de como as regras elaboradas afetarão sua capacidade de vitória política no futuro, 
através de vitória eleitoral ou influência política. O foco estaria em descrever as motivações individuais ou partidárias para a adoção de certas escolhas constitucionais. Alguns autores mostram evidências de como a influência partidária possui papel fundamental em explicar a escolha de regras eleitorais (Benoit, 2004, 2007; Negretto, 2006), uma vez que tais regras determinam a competição política no período posterior. A mesma lógica pode servir para explicar a escolha do sistema de governo, uma vez que a competição eleitoral e a alocação de poder estariam em jogo na definição deste desenho institucional.

As três hipóteses descritas acima fazem sentido no caso brasileiro da escolha do sistema de governo na Assembleia Constituinte de 1987-88. Veremos nesse trabalho como forças precedentes influenciaram decisivamente o processo de escolha institucional, mas também tiveram peso os argumentos normativos elaborados de lado a lado, bem como a força dos interesses mais imediatos e organizados. O que torna o caso brasileiro interessante é justamente essa combinação de elementos no processo de decisão constituinte, mas que podem ser individualizados e identificados, seja em termos de atores, ideias, preferências e contexto. É o que pretendemos demonstrar nos próximos capítulos.

Ao estudar o processo decisório da escolha do sistema de governo na Assembleia Nacional Constituinte de 1987-88, a questão que interessa responder é por que neste momento histórico foi feita a escolha pelo presidencialismo, e não pelo parlamentarismo que muitos acreditavam ser a melhor opção para o país e que contava com um forte apelo entre os constituintes. Para tal é necessário investigar quais eram os grupos que defendiam os diferentes desenhos institucionais para o sistema de governo, como o assunto foi tratado ao longo do extenso processo decisório, e também como as condições específicas da Assembleia Nacional Constituinte estruturaram o debate e a decisão final. 


\section{Capítulo 1 - O Presidencialismo, Seus Críticos e De-}

\section{fensores}

O período entre o começo dos anos 80 e meados dos anos 90, frequentemente referido como a "década perdida", foi marcado por uma grave crise econômica com forte repercussão sobre a estabilidade política. Naquele cenário, o diagnóstico predominante era que o sistema político não estava à altura dos desafios impostos pela crise, especialmente graças à fragmentação do sistema partidário e à corrupção impregnada tanto no Executivo quanto no Legislativo. Exemplos máximos da espiral de crise política na qual mergulhou o país por causa desses fatores foram o impeachment de Fernando Collor de Mello em 1992 - o primeiro presidente eleito diretamente após o regime militar - sob acusações de tráfico de influência e crime de responsabilidade, e também o escândalo dos "anões do orçamento", um esquema de corrupção que envolvia ao menos 43 membros do congresso, vários funcionários públicos e um cartel de construtoras que controlavam as obras públicas em várias partes do país (Fleischer, 1996, p. 299-300).

No período que vai das "Diretas-Já" ao plebiscito de 1993, passando pela elaboração da Constituição de 1988, houve um intenso debate no âmbito acadêmico e político sobre o sistema de governo no Brasil e as possibilidades de reforma, envolvendo avaliações sobre as virtudes e problemas dos diferentes tipos disponíveis, teóricos e empíricos. Nesse debate, defensores do parlamentarismo predominaram no meio acadêmico, tendo em Bolívar Lamounier sua principal referência. A visão deste grupo estava alinhada com a literatura internacional, inclusive contando com a participação de alguns deles nos debates nacionais, como foi o caso de Juan Linz (1991).

Além de visões normativas a respeito de qual sistema é melhor, houve também uma tendência de se distanciar das considerações a respeito de tipos ideais de presidencialismo e parlamentarismo, aproximando-se de um esforço em debater quais seriam os problemas institucionais brasileiros, o que estava funcionando e o que era problemático, e quais soluções poderiam ser adotadas. Nessa discussão, eram associados ao presidencialismo outros problemas, como o sistema eleitoral e o sistema partidário. A representação proporcional 
de lista aberta era vista como um dos principais males para o bom funcionamento democrático do país, uma vez que os líderes dos partidos teriam pouco ou nenhum controle sobre a lista partidária de candidatos, além do individualismo que tal sistema incentivaria, tanto na arena eleitoral- na disputa por votos - quanto na arena legislativa - na busca por políticas em prol de seu reduto eleitoral -, não havendo incentivos para que houvesse qualquer disciplina partidária no Congresso.

Não por acaso, os debates em torno do plebiscito se concentraram em dois temas, os problemas de governabilidade (como a habilidade do governo em responder eficientemente às crises e mudanças no ambiente político) e a falta de confiança da população nas instituições políticas. Argumentava-se que o sistema parlamentarista ajudaria a criar condições necessárias para a aprovação de reformas sociais e econômicas, dada a condição de que o governo teria apoio de uma maioria parlamentar no Congresso.

As críticas que os defensores da mudança no sistema de governo faziam eram ressonância do momento político brasileiro da década de 1980 e começo dos anos 1990. O mandato presidencial de José Sarney havia diso bastante problemático, tanto no âmbito político quanto no econômico. A eleição de Fernando Collor de Mello também foi emblemática. Tido como um outsider da política, teria tentado governar acima dos partidos pois o seu próprio, o PRN, só contava com 3\% das cadeiras no Congresso. Implementou um plano de estabilização econômica sem negociações prévias, e foi destituído do poder devido a escândalos de corrupção.

Neste capítulo apresentaremos o debate acadêmico que ocorreu neste período. O foco não será discutir qual sistema de governo seria melhor, mas sim apresentar o diagnóstico realizado a respeito das instituições políticas brasileiras, principalmente do presidencialismo. Na primeira seção apresentaremos como os autores criticavam o sistema político nacional, sendo constante a defesa da implementação do sistema parlamentarista. Na segunda seção daremos ênfase a alguns autores que defenderam a manutenção do presidencialismo no debate da época. Em seguida, será exposta a literatura que explica o funcionamento do presidencialismo que opera desde 1988, o "presidencialismo de coalizão". 


\section{Seção I - Os críticos}

Foi Abranches (1988) quem cunhou a expressão "presidencialismo de coalizão", em seu artigo pioneiro escrito antes da promulgação da Constituição de 1988. O autor afirma que o sistema político brasileiro seria peculiar ao combinar a representação proporcional, o multipartidarismo e "presidencialismo imperial", além de ter o Executivo organizado com base em grandes coalizões político-partidárias e regionais. Seria essa combinação que caracterizaria o regime político-institucional brasileiro como um "presidencialismo de coalizão". Ou seja, um governo não seria capaz de viabilizar e implementar seus projetos políticos sem ter como base o apoio político do Congresso Nacional e dos estados da federação brasileira.

Segundo Abranches, a constituição dessa base de apoio político não se daria em um único momento nem se tornaria definitiva, mas apresentava sim uma dinâmica processual, baseada em três momentos: a chamada "constituição da aliança eleitoral", quando seria elaborado um programa e princípios políticos amplos e mínimos para a composição da aliança, a serem considerados na formação do governo após a vitória eleitoral; a "constituição do governo", que teria relação direta com a distribuição de cargos e compromissos genéricos com a base de apoio político estabelecida na aliança eleitoral; e a "transformação da aliança em coalizão efetivamente governante", que seria o processo de formulação e implantação das políticas governamentais.

Devido a essas características atribuídas ao presidencialismo brasileiro, Abranches faz um diagnóstico pessimista do sistema político brasileiro, sendo este um sistema instável, baseado no clientelismo e na patronagem, e oferecendo altos riscos para a transição democrática.

Bolívar Lamounier possuía uma preocupação semelhante. Este autor se dedicou a defender o parlamentarismo em diversos trabalhos (Lamounier, 1990, 1991, 1992; Lamounier e Nohlen, 1993), apontando os problemas que o presidencialismo brasileiro acarretaria, e argumentando que o parlamentarismo poderia ajudar a modificar o cenário pessimista que pariava sobre o sistema político nacional. Dessa forma, ele atenta para a necessidade de um debate sobre qual sistema de governo seria melhor para a consolidação democrática, 
sempre defendendo que o parlamentarismo seria o ideal.

Para este autor, a governabilidade no sistema político brasileiro seria problemática devido ao alto grau de consociativismo, nos termos de Lijphart (2003), presente em nosso sistema eleitoral e partidário, e na organização federativa. Ao estimular a fragmentação política, nossas instituições dificultariam composições de governo estáveis. A propensão à ingovernabilidade estaria na orientação de bloqueios às decisões da maioria. O alto custo de se implementar decisões nos conduziriam a uma "poliarquia perversa". Tal grau de consociativismo seria exagerado para nosso país, pois costumeiramente seria implementado apenas em sociedades com grandes clivagens sociais.

O caráter consociativo brasileiro seria composto pela representação proporcional de lista aberta, o pluripartidarismo, o regime federativo, o bicameralismo com duas casas fortes, e a Constituição rígida e detalhada. O processo de adoção de tais características teria se iniciado após a Revolução de 1930, na intenção de acabar com as oligarquias estaduais da República Velha e o governismo, possibilitando o surgimento de uma oposição. A Assembleia Nacional Constituinte de 1987/88 teria mantido e ampliado esse consociativismo.

A fragmentação partidária é uma das principais preocupações apontadas por Bolívar Lamounier. A probabilidade de que o governo seja minoria, e ainda mais por ser uma minoria acentuada, seria um problema grande pois não teríamos fatores institucionais a compensar esta tendência, incentivando a formação de maiorias estáveis. As únicas forças unificadoras, que atrairiam os parlamentares a se alinharem com o Executivo, seriam o fisiologismo e a popularidade plebiscitária do presidente, mas mesmos estes dois atrativos estariam mais associados à estratégias de reeleição dos parlamentares do que a incentivos consistentes em prol da governabilidade.

O presidencialismo ainda teria um problema de efetividade em nosso país, devido ao nosso sistema partidário, que seria o clientelismo. A fragilidade, instabilidade e indefinição de nossos partidos fariam com que as demandas eleitorais fossem do tipo extrativa, sob a forma de favorecimentos, e não através de políticas públicas formuladas e implementadas no longo prazo. Mesmo após cem anos de presidencialismo os partidos ainda seriam 
obstáculos à programas governamentais.

Ainda sobre o sistema eleitoral e partidário, o autor faz uma crítica ao sistema proporcional e à visão de que esse seria o sistema que melhor representaria a opinião do eleitorado, facilitando o acesso ao legislativo de todas as correntes partidárias. Na realidade, o sistema proporcional brasileiro não facilitaria a representação dos diversos interesses da sociedade, mas sim a representação de todos os partidos, o que não seria a mesma coisa dada a fragilidade e falta de enraizamento dos partidos em nossa sociedade. Assim, a proporcionalidade facilitaria o fracionamento da classe política. Para Lamounier, mais importante seria conferir força a uma corrente majoritária, diminuindo os custos de negociar com outros partidos.

Para se contrapor ao forte caráter consociativo, haveria se estabelecido no Brasil uma hipótese político-institucional de que o presidencialismo plebiscitário seria uma força unificadora, imprimindo uma coerência ao sistema político, estabelecendo os rumos políticos do país, com a capacidade de disciplinar os particularismos, vencer resistências e mobilizar o apoio necessário para implementar as reformas sociais rumo ao avanço, baseado em seu apoio eleitoral. Porém, segundo Lamounier, haveria um risco nesta crença devido a "anemia parlamentar" dos presidentes, que resultaria em uma inefetividade decisória. Alguns fatores indicariam que os próprios presidentes não teriam tal liderança estabilizadora.

O principal indicador da falta de estabilidade dos presidentes seria o fato de que a maioria dos mandatos presidenciais civis e eleitos democraticamente não foi cumprida até o final. Vale lembrar que um argumento em prol do presidencialismo é o de que presidentes não podem ser removidos antes do prazo constitucionalmente estabelecido, o que lhes daria a autonomia e a estabilidade necessárias para enfrentar dificuldades. Porém isso não se verificaria no caso brasileiro. Até então, apenas Dutra e Juscelino seriam exemplos de presidentes democraticamente eleitos que teriam conseguido concluir seus mandatos.

O caráter plebiscitário do nosso sistema presidencialista também seria perigoso por dois motivos. Ao se apoiar apenas em sua legitimidade eleitoral, 1) o presidente que sofresse uma erosão de seu apoio popular mergulharia em perigoso isolamento. Um sinal de que isso era algo frequente no Brasil, inclusive entre os militares, era o fato de que poucos 
presidentes conseguiram exercer influência na escolha de seus sucessores; 2) de outro lado, diante de um apoio eleitoral plebiscitário muito grande ao presidente, a oposição era levada a crer na possibilidade de rompimento das regras do jogo para ampliar seu próprio poder, como aconteceu na renúncia de Jânio Quadros ou no governo João Goulart. De qualquer forma, ambas tendências seriam prejudiciais ao regime democrático.

O problema do regime presidencialista brasileiro, segundo Bolívar, seria a falta de incentivos institucionais para a formação de uma base parlamentar estável. A inefetividade decisória acabaria por ser uma ameaça ao próprio regime democrático. Dessa forma, além do parlamentarismo, o autor defende que o caráter consociativo seja amenizado. Lamounier defende que a implementação do parlamentarismo reverteria esse quadro pessimista diagnosticado por ele.

Bolívar reconhece algumas dificuldades na implementação de um novo sistema parlamentarista. A primeira delas seria a tradição presidencialista enraizada em nossa cultura latino-americana. Nossa cultura política teria preferência por lideranças fortes e personalistas, rejeitando a forma impessoal como se constitui a liderança política no parlamentarismo. No entanto, o fato de que o presidencialismo não teria tido sucesso em estabelecer-se de forma estável, eficaz e legítima facilitaria a mudança.

Durante a República Velha, a "política dos governadores" teria impedido que houvesse um fortalecimento da figura presidencial, prejudicando o início de eleições competitivas e formação de um eleitorado e partidos nacionais devido ao predomínio das oligarquias estaduais. O ciclo getulista teria fortalecido o cargo presidencial, identificando-o com um projeto de construção do Estado nacional, e os arranjos institucionais elaborados neste período estariam enraizados até hoje no sistema político brasileiro. Porém seu surgimento teria se dado à margem do apoio eleitoral, uma vez que Getúlio perdeu as eleições de 1930 e teria tomado o poder sustentado pelas elites dissidentes. Seu prestígio eleitoral teria sido adquirido aos poucos, através das políticas por ele implementadas. Esse seria um claro exemplo de que não seria condição necessária para o surgimento de um líder o apoio plebiscitário, mas sim a condução eficaz de uma agenda política. Até 1945 o regime presidencialista não teria sido verdadeiramente testado, devido à fragilidade do sistema 
na Primeira República com seu caráter oligárquico e eleitorado ainda em formação, e pelo fato de que o ciclo getulista teria sido iniciado de forma revolucionária e terminado de forma ditatorial.

Foi a partir de 1945 que o eleitorado se estabeleceu através de eleições competitivas em âmbito nacional. Neste momento é que se inicia a necessidade presidencial de obter o capital plebiscitário através do apoio popular ao mesmo tempo em que necessitaria de apoio congressual por meio de coalizões. Tal regime teria fracassado pois haveria um baixo nível de institucionalização partidária no país, dificultada pelo sistema presidencialista, federalista, com eleições de representação proporcional.

Apesar de nossa tradição presidencialista, mal sucedida segundo Bolívar, haveria um crescimento da aspiração parlamentarista presente na sociedade. Durante o primeiro regime repúblicano, o parlamentarismo não seria uma ideia concebível devido a sua indentificação com a monarquia. Foi em reação ao getulismo que surgiram pequenos grupos críticos ao presidencialismo, tendo em Raul Pilla seu principal porta voz. Foi ele quem elaborou o modelo parlamentarista improvisado em 1961. Com o golpe de 1964, o movimento parlamentarista desapareceu pois tornara-se sem sentido devido a atmosfera autoritária.

Com a redemocratização, haveria pressões e expectativas contraditórias em relação ao sistema de governo a ser adotado na Assembleia Nacional Constituinte. Por um lado, haveria um crescimento da demanda por um plebiscitarismo através da campanha das "Diretas Já". Por outro lado o governo Sarney encontrava-se em sérias dificuldades. Porém, na Comissão Afonso Arinos, comissão de notáveis nomeados por Sarney para formular uma proposta de Constituição a ser encaminhada para a Assembleia Nacional Constituinte, foi aprovada uma forma de parlamentarismo dual que se assemelhava ao modelo francês. Esse teria sido um dos motivos pelos quais Sarney teria engavetado o projeto. Outro sinal de tendência crescente do parlamentarismo foi uma pesquisa realizada pela revista Veja (4/2/1987), na qual era constatada uma maioria de constituintes que preferiam a implementação do sistema parlamentarista. O grupo parlamentarista teria aumentado devido à crise do governo Sarney pós-Plano Cruzado, e devido à possibilidade de encurtar o mandato do presidente, ou ao menos de substituí-lo por um Primeiro-Ministro. No 
entanto, a proposta parlamentarista viria a ser derrotada, como veremos, por diversos fatores. Candidatos potencialmente fortes, os militares de alta patente, líderes empresariais, governadores estaduais e a esquerda plebiscitária (PT e PDT) teriam formado, na visão de Lamounier, a ampla coligação antiparlamentarista que impedirá a mudança dos sistema de governo.

Após a aprovação do presidencialismo na Assembleia Nacional Constituinte, o parlamentarismo teria ganhado ainda mais forças, devido a uma reavaliação da governabilidade sob o sistema presidencial. Tal tendência teria ocorrido devido aos fracassos do governo Sarney em controlar a inflação mas também por dois outros motivos. O primeiro seria o fortalecimento que o Congresso teria tido sob a nova Constituição, passando a ter um papel muito maior na elaboração orçamentária e em outros assuntos administrativos e econômicos que antes ficavam a cargo somente do presidente. O segundo seria o entendimento de que sob o parlamentarismo haveria mais chances de se combater os comportamentos clientelistas dos parlamentares, através da mudança da estrutura institucional, aumentando sua responsabilidade na tarefa de governar.

Scott Mainwaring é um dos principais brasilianistas a participar do debate da época a respeito das instituições políticas brasileiras, e um dos mais críticos. Em seus trabalhos $(1991 ; 1993)$ procura criticar o sistema presidencialista multipartidário vigente no país. Para este autor, o problema de instabilidade política que teríamos sofrido em nossos regimes democráticos seria decorrente da fragmentação partidária combinada com o presidencialismo, pois o presidente quase nunca teria maioria no Congresso, resultando em imobilismo político. O presidente não possuiria meio institucionais para construir uma maioria estável. Assim, ele teria poder de implementar políticas apenas em momentos em que sua popularidade estivesse alta, pois atrairia políticos de todos os partidos. Sem popularidade, a necessidade faria com que o presidente se esforçasse em fazer coalizões multipartidárias baseadas na patronagem, ou que passasse por cima dos partidos, tentando mobilizar as massas e enfraquecendo as instituições políticas e ameaçando o regime democrático.

Haveria um impasse constante entre o Executivo e o Legislativo, resultado do sistema 
multipartidário fragmentado com partidos indisciplinados. A falta de apoio estável no Congresso se daria com todos os presidentes eleitos, com excessão de Dutra, pois seus partidos não teriam conquistado maioria. O regime parlamentarista, segundo o autor, estaria mais adequado para lidar com uma situação desta. Seria improvável que o partido do presidente obtivesse maioria parlamentar pois o país teria um dos sistemas partidários mais fragmentados do mundo. Isso seria decorrência do sistema eleitoral e suas diversas características que facilitariam o acesso dos partidos ao Congresso, como o sistema proporcional, distritos de magnitude alta, possibilidade de fazer coligações e inexistência de uma cláusula de barreira.

Mesmo possuindo um Executivo forte quando comparado com o presidencialismo norte-americano, nosso sistema necessitaria de uma base de apoio parlamentar para bem funcionar. Apesar de existirem recursos para que se governe através de um presidencialismo imperial, pelo uso de medidas provisórias de forma indiscriminada, presidentes precisam governar por meio de leis cuja aprovação depende do Congresso. Prerrogativas legislativas não fariam com que o presidente conseguisse governar por si só. Sinal disso seria que na Primeira República os presidentes possuíam maior controle sobre o processo legislativo, mesmo tendo menos prerrogativas que no regime de 1946. A diferença estaria no sistema partidário.

Uma evidência de que nossos partidos seriam problemáticos seria a indisciplina partidária presente tanto no regime de 1946, quanto no regime de 1985. Os partidos seriam incapazes de impor uma disciplina centralizada. Haveria uma grande autonomia dos políticos, favorecendo o comportamento individual. Um reflexo disso seria a alta migração partidária, com políticos mudando de partido de acordo com seu interesse momentâneo.

O único recurso que o presidente possuiria seria a patronagem e o clientelismo, tornando a política mais personalista e menos institucionalizada. Seria necessário comprar o apoio de parlamentares individualmente, através da oferta de cargos e recursos, ou ameaçando privá-los de meios de manterem suas bases eleitorais. Tais características estariam presentes em diversos sistemas políticos, mas seria exacerbado no Brasil.

Não seria incomum que devido a essas debilidades presentes no poder Executivo, os 
presidentes adotassem uma postura antipartidária, ou suprapartidária. Para obter sucesso, o carisma pessoal teria que ser enfatizado através de sua personalidade e apostando em ligações pessoais. Apesar de admitir que em todos os países presidencialistas há uma necessidade de que a figura do presidente represente mais a nação do que seus partidos, no Brasil haveria uma necessidade de se distanciar dos partidos de forma extrema.

O sistema presidencialista seria desfavorável para a tentativa de formação de coalizões, ao contrário do parlamentarismo. No Brasil, os presidentes tentariam formar alianças amplas, iniciando-se na fase de pré-campanha eleitoral, e posteriormente através da patronagem, com a distribuição de posições em ministérios, empresas públicas, etc. Apesar de distribuírem cargos para diversos partidos, o sistema político não favoreceia a obtenção de apoio de partidos, mas apenas de políticos individuais.

No sistema parlamentarista, a formação de coalizões seria facilitada. No parlamentarismo os partidos participam diretamente da formação do gabinete ministerial e da escolha do primeiro-ministro. Tais acordos seriam mais consistentes do que no presidencialismo pois teriam vínculos mais fortes. No presidencialismo a responsabilidade de nomeação ministerial é inteiramente do presidente, possuindo mais liberdade devido a um arranjo institucional mais frouxo. Um segundo fator favorável à formação de coalizões no parlamentarismo seria a obrigação do parlamentar individual de apoiar o posicionamento de seu partido em relação ao governo. No Brasil, os legisladores teriam mais liberdade, fazendo com que se comprometam menos com o partido ou o governo. A terceira diferença entre os sistemas seria de que no parlamentarismo os partidos estariam comprometidos com a sustentação do governo, pois se o governo falhar, há risco de que se convoquem novas eleições. Já no presidencialismo, mesmo que diferentes partidos participem de diversos ministérios, estes não seriam responsáveis por sustentar o governo.

Segundo Mainwaring, não só o sistema eleitoral e partidário faz com que o presidencialismo tenha dificuldades em funcionar de maneira estável, como o próprio presidencialismo faz com que o sistema partidário se enfraqueça. Enquadrado em um sistema fragmentado, sem base de apoio no Congresso, a alternativa do presidente seria a de enfraquecer os partidos. 
Em um dos textos que compõem o livro "Presidencialismo ou parlamentarismo" (1993), Stepan e Skach observam que a maioria das novas democracias adotou o presidencialismo, com a totalidade no caso das democracias da América Latina e da Ásia. No entanto, os autores afirmam que tal atitudade deveria ser reconsiderada. Ao analisarem alguns dados sobre o regime democrático de diversos países e a sobrevivência destes regimes, chegaram à conclusão que o sistema parlamentarista possui chance muito maior de sobreviver, tendo a chance três vezes maior em relação ao sistema presidencilista de resistir a golpes de Estado, e metade de chance de sucumbir a um golpe militar. Além disso, ao verificar a produção de maiorias legislativas, condição necessária para implementação de programas políticos segundo os autores, observaram que o partido do presidente contava com maioria legislativa em menos da metade do tempo de mandato, enquanto os partidos dos primeiroministros obtinham maioria em pelo menos $83 \%$ do tempo. Em relação à duração e renomeação de ministros de gabinete, os autores observam que o percentual de ministros que ocupam um cargo mais de uma vez em suas carreiras políticas é quase trêz vezes maior nas democracias parlamentaristas que nas presidencialistas, e o tempo médio de permanência no cargo é quase o dobro no sistema parlamentarista quando comparado ao presidencilista. A maior experiência e permanência dos ministros facilitaria a continuidade e capacidade política dos governos.

Por estimular a dependência mútua entre os poderes, fazendo surgir incentivos para criação e manutenção de maiorias de um só partido ou coalizão, o sistema parlamentarista seria mais favorável para a consolidação democrática, e desencorajaria a sociedade a apoiar golpes militares. Ao contrário, o presidencialismo estimularia uma independência mútua entre os poderes, incentivando a emergência de governos minoritários, aumentando o impasse legislativo e estimulando a sociedade a reivindicar golpes militares.

Um dos autores que possuíram maior influência neste debate na literatura de política comparada, e que influenciou os autores apresentados anteriormente nesta seção, foi Juan Linz. Um de seus textos compôs o livro "A opção parlamentarista" (1991), que foi organizado por Bolívar Lamounier para alimentar o debate no período pré-plebiscito de 1993. Ao expor as características dos sistemas presidencialistas e parlamentaristas, o 
autor afirma que nenhum dos dois pode resolver os problemas de todos os países, mas o parlamentarismo teria mais vantagens para sustentar um democracia estável.

Linz elenca uma série de características do presidencialismo que provocariam problemas estruturais inerentes a este sistema de governo. Estão entre eles a simultânea legitimidade democrática do presidente e do Congresso, a falta de mecanismos para resolução de conflitos e a rigidez de períodos fixos de mandato. Com relação ao parlamentarismo, o autor afirma que mesmo possuindo algumas características sujeitas a críticas, várias democracias parlamentaristas conseguiram superar os resultados não funcionais gerados por tal sistema, favorecendo o surgimento de fortes lideranças nacionais e partidárias, possuindo capacidade de governar mesmo em situações críticas. Dessa forma, as evidências acumuladas a respeito dos sistemas presidencialistas da América Latina e Ásia, e sobre os sistemas parlamentaristas da Europa Ocidental, demonstrariam que as possibilidades de sucesso seriam maiores com instituições parlamentaristas.

A hipótese de que o sistema presidencialista é inferior ao sistema parlamentarista, ainda mais quando combinado com o multipartidarismo e eleições proporcionais de lista aberta, é parte fundamental da literatura desenvolvida tanto a respeito das instituições brasileiras quanto na área de política comparada. Os trabalhos apresentados contribuíram para o desenvolvimento do debate a respeito da dinâmica das instituições políticas, influenciando diversos outros desenvolvidos posteriormente. Estes autores defendem a tese de que a combinação das instituições adotadas pelo Brasil produziria instabilidade institucional e pouca governabilidade. Ao enfatizarem o efeito que as instituições do sistema de governo provocariam no comportamento de atores políticos, apoiando-se em premissas motivacionais e comportamentais (e não tanto em dados empíricos), estes autores defendiam o parlamentarismo como o melhor sistema de governo a ser adotado para a consolidação democrática das novas democracias.

\section{Seção II - Os defensores}

Apesar de todas as críticas predominantes na época ao sistema presidencialista, associado com o sistema eleitoral e partidário vigentes no país, esse sistema de governo se 
manteve. Na Assembleia Nacional Constituinte de 1987/88, o presidencialismo obteve 343 votos em plenário, aproximadamente $61 \%$ dos votos, contra 213 votos a favor do parlamentarismo, aproximadamente 39\%. No plebiscito de 1993 foi a vez do eleitorado ratificar definitivamente a vigência do presidencialismo com $69,2 \%$ dos votos válidos contra 30,8\% dos votos para o parlamentarismo. Após essas definições, foram apresentados dois projetos de emenda constitucional, o primeiro feito pelo deputado Eduardo Jorge e o segundo pelo deputado Roberto Jefferson, porém ambos foram arquivados.

As manifestações acadêmicas em favor da manutenção do presidencialismo, quando comparados com os parlamentaristas, são escassas. Talvez seja devido à literatura internacional que na época se inclinava a defender o parlamentarismo criticando o presidencialismo nos moldes brasileiros, e também a falta de estudos nacionais sobre o funcionamento das instituições brasileiras. Foram poucos os que se manifestaram através de artigos ou livros em prol do presidencialismo.

Antes do plebiscito de 1993, momento em que houve um amplo esforço de debater as instituições políticas brasileiras, um livro reuniu alguns artigos acadêmicos que defendiam a manutenção do sistema presidencial. Em "Em defesa do Presidencialismo" (1993) , três cientistas políticos de grande nome na literatura nacional, Leôncio Martins Rodrigues, Renato Lessa e Wanderley Guilherme dos Santos, sustentaram suas opiniões em relação ao sistema de governo que deveria ser o vencedor do plebiscito naquele ano.

Leôncio Martins Rodrigues abre o livro, e inicia seu argumento afirmando que faz parte da cultura brasileira acreditar que através de reformas institucionais pode-se chegar à virtude política e à "boa sociedade". Sinal disso seriam as várias Constituições já feitas, as diversas legislações eleitorais que entraram em vigor, sem que se desse tempo para que nossas instituições se estabelecessem solidamente. O desejo de fazer mudanças bruscas prevaleceria à alternativa de fazer melhoras incrementais ao que já temos. Para criar uma cultura cívica, necessitaríamos que houvesse uma continuidade maior nas regras do jogo a fim de criar uma tradição democrática tanto nos cidadãos quanto nas elites. Consequentemente, as mudanças deveriam ocorrer de forma mais lenta e moderada. A mudança constante de regras acarretaria mais custos de informação ao eleitor sobre as 
novas regras, o que tenderia a reforçar condutas de retirada da participação eleitoral e de aumento na desconfiança com relação aos políticos.

O primeiro argumento que Rodrigues lança mão é que não há evidências empíricas de que o parlamentarismo seja melhor que o presidencialismo em termos de governabilidade, estabilidade, representatividade ou qualquer outro tipo de resultado. Tais evidências seriam difíceis de serem obtidas devido às especificidades de cada sociedade e à existência de diversos modelos parlamentaristas, dificultando muito a tentativa de avaliação comparativa. No que diz às peculiaridades brasileiras, o parlamentarismo seria problemático devido ao nosso sistema partidário fragmentado, que dificultaria a formação de gabinetes estáveis.

O segundo argumento é de que, caso o parlamentarismo vencesse o plebiscito, não se saberia qual tipo de parlamentarismo seria implantado. Algumas questões institucionais teriam que ser postas em pauta e discutidas tais como: qual seria o papel do Senado? Como se daria a eleição do primeiro ministro em um sistema eleitoral fragmentado? Como se daria a distribuição de poder entre o chefe de governo e o chefe do Executivo? Como se dariam as eleições estaduais e municipais? Essas indefinições poderiam acarretar sérios problemas de ordem institucional, agravados ainda pela proximidade das eleições de 1994 . O alto custo de praticamente paralisar o sistema político para uma redefinição de seu funcionamento, caso o parlamentarismo vencesse, não compensaria os benefícios incertos e duvidosos de sua instalação.

O último argumento é o de que dificilmente seria adotado um parlamentarismo puro, sem eleição de um chefe de governo por via das eleições diretas devido à nossa tradição presidencialista, ainda mais reforçada pela campanha das "Diretas Já". O problema seria que isso acabaria por manter, ou até mesmo agravar o problema de eleger um presidente sem base parlamentar. Ao falar sobre o parlamentarismo britânico e sobre o presidencialismo americano, deixa claro que o mérito do sucesso desses sistemas seria o bipartidarismo.

Rodrigues aponta ainda a preocupação com alguns aspectos presentes no país que dificultariam o estabelecimento de um regime democrático, seja qual sistema de governo fosse adotado. Alguns exemplos seriam a cultura politica latino-americana que cria condições 
para o estabelecimento de regimes autoritários, o sistema social e econômico.

Renato Lessa inicia seu artigo constatando que existem inúmeras formas de governo que acabam por ter combinações muito diferentes devido às diversas particularidades de cada país, sendo difícil defender que qualquer modelo seja implementado em um país tendo como referência o bom funcionamento em outra nação. O sucesso de certas instituições ocorreria mais por serem expressões que duram no tempo do que por questões de superioridade doutrinária.

A principal preocupação deste autor está em melhorar a produção do governo e a constituição de representação. Ao se perguntar sobre qual maneira maximizaria o peso do voto popular na configuração do mundo público, Lessa afirma que, a partir da história republicana pós-46, o voto do cidadão brasileiro possui dois papéis: eleger a representação e escolher quem governa. O parlamentarismo europeu estaria limitado apenas à escolha da representação. Dessa forma, o presidencialismo, juntamente com a representação proporcional, seria um "privilégio institucional", pois maximizaria o peso do voto popular.

Wanderley Guilherme dos Santos associa parlamentarismo ao voto majoritário distrital, e acaba por criticar este sistema eleitoral e defender o sistema proporcional ao invés de criticar o parlamentarismo e promover o presidencialismo. Porém seu argumento é útil para rebater as críticas que parlamentaristas dirigem à fragmentação partidária e a impossibilidade de existir um presidencialismo multipartidário estável. O primeiro ponto que o autor destaca é que estabilidade política não é consequência de instituições políticas, pois não haveria demonstrações teóricas ou empíricas para tal. Sendo assim, implementar o voto majoritário para garantir uma melhor estabilidade política, prejudicando a correspondência entre a distribuição de preferências do eleitorado e distribuição de poder parlamentar, seria uma medida equivocada.

A partir de então, Santos aponta que existem algumas afirmações tidas como "fatos verdadeiros" em defesa da implementação do sistema majoritário, mas que na verdade são propagandas errôneas. A primeira delas seria a ideia de que a maioria das democracias estáveis adotaria o sistema majoritário. O autor aponta que, ao contrário, apenas 7 países teriam tal sistema, contra 16 democracias que usariam o sistema proporcional. A segunda 
afirmação equivocada seria a de que a tendência das democracias seria substituir o sistema proporcional pelo sistema majoritário. Mas na realidade, todos os países teriam optado pela representação proporcional após terem uma longa experiência com a representação majoritária.

A terceira ideia é de que haveria uma diminuição do custo de competição eleitoral. A afirmação estaria errada pois toda competição democrática seria cara. Em sistemas proporcionais devido à abundância de competidores, e em sistemas majoritários devido à escassez de postos em disputa. A quarta afirmação incorreta é a de que o sistema majoritário aproxima o representando do representado. Pelo contrário, este sistema faccionalizaria o eleitorado, fazendo com que o eleito legisle para seus eleitores na intenção de conservá-los, deixando as minorias à margem do sistema político. A quinta afirmação seria a de que haveria maior qualidade da representação através do sistema majoritário, mas evidências mostrariam que escândalos e corrupção também existem sob este sistema.

No âmbito do processo legislativo, afirma-se a sexta ideia de que o sistema majoritário garantiria eficiência parlamentar. O autor refuta afirmando que toda a literatura contemporânea estaria preocupada com a crise do Legislativo em todas as democracias. E finalmente em último, diria-se que o sistema majoritário garante inteligência legislativa através de melhores leis. Porém, isso dependeria da qualidade dos eleitos, coisa que tal sistema não teria como promover.

Em seguida, o autor defende que o sistema proporcional não seria responsável por causar fragmentação do eleitorado, proliferação de partidos e instabilidade governamental. Para ele, a relação seria oposta. O sistema proporcional é que se justificaria para captar e representar as diferentes preferências dos eleitores. E ainda, índices de fragmentação partidária não diriam nada a respeito da estabilidade dos sistemas democráticos. Ainda mais se considerados o número de partidos efetivos. A defesa do sistema proporcional se dá devido à preocupação do autor com a representação política das minorias. Santos se coloca contra a tirania da maioria, e parte em defesa dos partidos "nanicos".

Por fim, faz uma defesa pela estabilidade institucional, afirmando que não se pode tentar implementar instituições esperando os mesmos resultados observados em outras 
democracias. Instituições seriam resultado de uma evolução, adaptar-se-iam aos problemas correntes. Seria muito custoso iniciar uma mudança institucional radical tendo em vista que os benefícios seriam incertos. Segundo o autor, haveria até evidências de que países institucionalmente subdesenvolvidos e instáveis seriam países que procuraram o mimetismo institucional.

Os autores apresentados defendem o presidencialismo, em resumo, argumentando que na falta de evidências empíricas de que o parlamentarismo seja superior ao presidencialismo, seria melhor manter um certo ceticismo em relação à reforma institucional. O contexto da política nacional seria mais importante para avaliar as mudanças propostas do que a observação do funcionamento do parlamentarismo em outros países. O custo de alterar completamente nossas instituições políticas seria alto, pois todos os atores políticos teriam que se adaptar as novas regras, a legitimidade democrática dos poderes seria alterada e os resultados seriam incertos, inclusive pela falta de definição de qual sistema parlamentarista seria adotado na vitória do plebiscito. Dessa forma, haveria mais dúvidas e incertezas sobre como o parlamentarismo se adequaria ao nosso contexto do que certezas de bons resultados.

\section{Seção III - O presidencialismo de coalizão revisitado}

A perspectiva pessimista em relação às instituições políticas brasileiras, que marcou a primeira literatura tratada neste trabalho, começou a mudar em meados da década de 1990. O sistema presidencial brasileiro começou a ser alvo de estudos mais sistemáticos, através de investigações com o esforço pioneiro de buscar compreender o que realmente acontecia no Congresso Nacional. Ao se contraporem à visão apresentada no primeiro capítulo, essa literatura resgata a importância dos partidos no processo decisório e seu papel na produção legislativa na Câmara dos Deputados. Para tal, os novos estudos afirmam, sempre em bases empíricas, que o processo decisório é centralizado e favorável ao Executivo. O argumento central que está presente nessas análises é que os problemas que a primeira literatura afirma que seriam criados pelo sistema eleitoral e partidário são neutralizados na arena legislativa. O comportamento dos parlamentares seria influenci- 
ado pelos poderes legislativos do presidente da República e pelos partidos, através da centralização de poderes no Colégio de Líderes.

Em diversos trabalhos, Figueiredo e Limongi (1994; 1995; 1997; 1998; 2005; 2007) defendem que, quando comparada com o regime de 1946, a Constituição de 1988 alterou significamente a relação entre Poder Executivo e Poder Legislativo, conferindo ao presidente da República uma capacidade legislativa muito forte, situação que não poderia ter sido considerada por Abranches ao escrever seu trabalho sobre o presidencialismo de coalizão, já que foi escrito antes da promulgação da Constituição de 1988. Nestes estudos, os autores apontam que não há paralisia decisória ou inoperância na combinação do sistema presidencialista com o sistema proporcional de lista aberta e o multipartidarismo. Isso se dá porque a Constituição Federal de 1988 aumentou os poderes legislativos do presidente da República, facilitando a criação de coalizões partidárias.

Os autores afirmam que a Constituição de 1988 manteve as prerrogativas concedidas ao presidente da república durante o regime militar. A capacidade de editar medidas provisórias seria uma forma de continuidade dos decretos-leis. Além disso, o presidente agora possui o recurso da solicitação de urgência para os projetos de lei, para que as iniciativas que o interessem tenham prioridade no processo decisório. Esses dois recursos são exemplos de outros aspectos institucionais que a nova Carta constitucional conferiu ao Executivo, proporcionando-lhe um poder de agenda consideravelmente maior que o que existia durante o regime de 1946. Ainda mais, com a existência do colégio de líderes a partir de 1988, a disciplina partidária atinge índices que se aproximam ao dos sistemas parlamentaristas e de democracias ditas como estáveis. Dessa forma, o Congresso Nacional não é um obstáculo para as ações do Executivo.

Figueiredo e Limongi afirmavam haver chegado a conclusões totalmente contrárias às previsões feitas pela literatura no que se refere ao papel e comportamento dos partidos no Congresso. A literatura estaria equivocada ao apontar a fragilidade do funcionamento das instituições políticas brasileiras, devido a uma suposta fragmentação partidária exacerbada que resultaria em coalizões instáveis, sendo o cerne do equívoco o fato de que os diagnósticos apresentados seriam baseados exclusivamente no exame de aspectos da legis- 
lação eleitoral vigente. O engano estaria em desconsiderar as regras e procedimentos que regulam o processo decisório no Congresso Nacional e nos comportamentos que derivam daí. Com a nova distribuição de poderes parlamentares em vigor a partir de 1988, resultando em um maior poder de agenda do Executivo e a centralização do processo decisório no colégio de lideres, os efeitos do sistema eleitoral e partidário seriam neutralizados.

Para chegar a tais conclusões é frequente os autores compararem os regimes de 1946 e 1988, devido aos aspectos institucionais comum a ambos: o sistema proporcional de lista aberta, o multipartidarismo, além do presidencialismo e do federalismo. Se tais fatores causassem instabilidade política, os dois regimes sofreriam dos mesmos males. Em Figueiredo e Limongi (2007), por exemplo, com base em dados coletados durante os dois períodos sobre as votações do Congresso e as ações do Executivo, os autores demonstram que houve formação de coalizões governistas multipartidárias na maior parte das gestões presidenciais. Porém, sob o regime de 1988 o Executivo obteve muito mais sucesso na aprovação de sua agenda, graças a outras condições institucionais asseguradas pela nova Constituição e não existentes sob o regime de 1946. Essas novas condições não eram tão novas assim, pois eram oriundas do regime militar, que dotou o Executivo Federal de mais poderes que os governos anteriores. A Constituição de 1988 manteve muito destas características. Houve uma centralização do poder nas mãos do presidente e dos líderes partidários, o que tornou o sistema político pós-1988 mais eficaz ou, em outras palavras, capaz de aprovar mais projetos de lei propostos pelo Executivo. O Congresso, nesta argumentação, não é um ator fraco, mas decide sobre o sucesso do Executivo, delegando poder e apoiando os projetos de lei.

A primeira diferença institucional significativa entre os dois sistemas seria a ampliação da prerrogativa exclusiva de iniciar legislação do presidente. O instrumento mais forte nesse aspecto é a medida provisória, pois, de qualquer maneira, ela altera o status quo vigente. Após a promulgação de uma medida provisória, ao parlamento só restaria escolher entre o novo status quo ou outro que seria criado pela rejeição da medida. Por isso, com esse recurso, o presidente pode iniciar mudanças que dificilmente seriam rejeitadas pelo Congresso, o que não significa que ele possa dispensar o apoio da maioria parlamentar 
para manter a vigência das medidas. Citando Huber, os autores caracterizam as medidas provisórias como "instrumentos para resolver problemas de 'barganha horizontal', entre o governo e a maioria que lhe dá apoio" (p. 153). Ela protege a maioria governista de discussões delicadas, preservando coalizão majoritária que apoia o presidente.

Outra diferença institucional é a forma de organização do Congresso: a partir da Constituição de 1988, ela se dá através de uma concentração do poder nos cargos dos líderes partidários e do presidente da Câmara. Eles obtêm, por exemplo, o papel de determinar a pauta legislativa, de escolher os membros das comissões permanentes e especiais, e podem assinar petições em nome dos membros dos partidos. Tal concentração de poder ajuda a formar apoio majoritário para os projetos do Executivo. Ao privilegiar os líderes partidários no processo decisório, protegem-se os interesses partidários, pois torna-se possível neutralizar e punir a ação individualista de parlamentares que tentarem agir por conta própria para agradar sua base eleitoral.

Para deixar claro que uma estrutura decisória centralizada afeta o funcionamento de Legislativo, os autores apresentam dados sobre as taxas de dominância legislativa e de sucesso dos presidentes dos dois regimes democráticos em questão. Sob a Constituição de 1988, todos os presidentes obtiveram taxas altas e estáveis de sucesso e dominância. Isso seria evidência de que o Executivo controla a agenda legislativa do país, propondo alterações no status quo e sendo raramente derrotado. Tais características de produção legislativa são típicas de sistemas parlamentaristas, com o Executivo exercendo controle através da lógica de formação de coalizões. O domínio do Executivo se dá através de medidas provisórias, feitas principalmente para regular áreas administrativas e econômicas, o recurso de pedido de urgência que acaba por privilegiar projetos de interesse do Executivo com cooperação do Legislativo, através dos líderes partidários e os poderes que estes dispõem para disciplinar sua bancada. O apoio dos partidos é obtido através da distribuição de posições em ministérios.

Para demonstrar que o comportamento do legislativo é disciplinado pelos motivos anteriormente expostos, verifica-se que a coesão partidária do período pós-88 foi maior do que a do regime democrático anterior, e que a coalizão governista possui um comportamento 
mais homogêneo, indicando que o governo legisla contando com o apoio dos partidos de sua coalizão. Não apenas os parlamentares votam com os partidos, como os partidos da coalizão votam em sintonia com a posição do executivo na maioria das votações. E mais ainda, a coalizão atualmente seria formada em contiguidade ideológica com o partido do Executivo. Todos estes fatores tornam o comportamento do plenário altamente previsível.

O processo legislativo brasileiro atual é conduzido pelo Executivo. Mas isso não significa que o Legislativo esteja à parte do processo. Apesar das pautas deliberativas serem proposições originadas no Executivo em sua maioria, os parlamentares possuem o papel de apreciar, votar e fiscalizar as proposições do presidente da República.

Na literatura de política comparada, o trabalho de Cheibub (2007) também procura refutar a ideia de que presidencialismo e sua organização institucional não seja favorável à consolidação democrática. Ao analisar dados que cobrem todos os regimes democráticos que existiram entre 1946 e 2002, Cheibub afirma que tanto as consequências das instituções presidenciais alegadas pela literatura quanto as causas externas comunmente utilizadas (nível de desenvolvimento econômico, extensão do país e localização geográfica) não são observadas ou não são suficientes para explicar a diferença de duração entre democraciais presidencialistas e parlamentaristas. Em apenas dois casos o sistema presidencialista teria sucumbido devido a crise de governabilidade (Equador e Peru).

A explicação dada por Cheibub para o menor tempo de duração das democracias seria o legado autoritário de ditaduras militares. Democracias precedidas por ditaduras militares são mais instáveis do que aquelas precedidas por ditaduras civis. Uma possível explicação para tal está relacionada com o fato de que, uma vez inserida na política, é díficil controlar os militares. O sistema presidencialista tem uma taxa de sucesso menor quando comparado ao sistema parlamentarista pois tendem a suceder com mais frequência ditaduras militares. O problema é que tal sistema tende a existir em sociedades onde democracias de quaisquer tipo são instáveis. É a combinaçao dessas duas ocorrencias 1) democracias que sucedem ditaduras militares possuem maior tendência de se tornarem ditaduras e 2) regimes presidenciais possuem maior tendência de sucederem ditaduras militares - que faz com que regimes presidencialistas aparentemente sejam mais frágeis. 
Assim, a ideia de que instabilidade de tais regimes seria causada por incentivos gerados pelo presidencialismo não possui suporte em dados empíricos.

Em resumo, os trabalhos de Figueiredo e Limongi e de Cheibub enriqueceram o debate acadêmico sobre o funcionamento de nossas instituições apresentando dados empíricos e utilizando-se de argumentos teóricos que sustentam suas afirmações. Dessa maneira, contradizem as críticas feitas ao sistema atual pelos trabalhos produzidos na Ciência Política do inicio dos anos 1990. Os autores desmistificam as reservas ao presidencialismo. O caso brasileiro mostra que certos parâmetros institucionais podem alterar o comportamento dos atores políticos e levar a prática democrática para caminhos bem sucedidos. O uso adequado de dados e informações sobre o funcionamento concreto do presidencialismo fez com que a discussão a respeito do tema se colocasse em outros patamares. 


\section{Capítulo 2 - Estudos sobre a constituinte e a escolha do sistema de governo}

Apesar de alguns trabalhos evidenciarem a importância e centralidade do debate entre presidencialismo e parlamentarismo na Constituinte, nenhum deles se aprofunda no assunto, evidenciando como se deu o processo decisório em torno do tema, quais grupos defendiam quais posições, quais eram seus interesses, quais propostas foram feitas, etc. Mesmo após completar 25 anos, foram poucos os trabalhos acadêmicos de fôlego, na área da Ciência Política, que trataram da Constituinte de 1988, em relação à sua construção teórica e ao processo de mobilização, discussão e negociação que ocorreu até sua fase final de elaboração. É recorrente a afirmação de que existem poucos estudos sobre a Assembleia Nacional Constituinte e que, apesar de muito material disponível, há muito estudo ainda a ser feito (Araújo, 2009; Marcelino, Braga e Costa, 2010; Pilatti, 2008; Praça e Diniz, 2008). As justificativas para essa carência de pesquisas são diversas: a extensão temporal da Constituinte (foram 20 meses de trabalho deliberativo), a extensão do espaço decisório (que foi dividido em 34 foros), durante algum tempo o fato de ser um evento relativamente recente, que dificultaria uma observação distanciada do momento histórico, e até mesmo o excesso de material primário produzido que seria difícil de ser totalmente "digerido". Ao apenas diagnosticarem uma lacuna existente nos estudos da área, e não se aprofundarem no tema, deixam sem resposta a maioria das questões relevantes discutidas à época.

O processo decisório sobre o sistema de governo é um dos assuntos que ainda não foi muito bem explorado pela literatura. Tal questão se torna relevante, pois desde o início dos trabalhos da Constituinte houve um processo de reavaliação da trajetória políticoinstitucional brasileira a fim de se verificar quais elementos seriam responsáveis por causar instabilidade política. Ao longo dos debates, diversos pontos foram levantados como passíveis de reformas imediatas e urgentes, dentre eles o sistema de governo, que se tornou a grande questão da Assembleia Nacional Constituinte.

Essa questão já era polêmica antes mesmo de se iniciarem os trabalhos da Assembleia 
Nacional Constituinte. A Comissão Afonso Arinos foi criada por Sarney, a seu contragosto, para cumprir uma promessa feita por Tancredo. Seu objetivo era a elaboração de um anteprojeto de Constituição para servir de subsídio aos trabalhos constituintes. Tal comissão foi composta por convidados políticos, pesquisadores, juristas, e outras personalidades da sociedade civil. Seu projeto final não fora apresentado à Assembleia Nacional Constituinte, pois, influenciado pelo clima democratizante e participativo, recebeu duras críticas dos conservadores, que o desqualificam como ponto de partida para a elaboração constituinte. Um dos motivos para Sarney repudiar o anteprojeto foi o fato de a Comissão ter proposto um sistema de governo parlamentarista, ainda que misto (Silva, 1990).

Alguns trabalhos chegam a tratar superficialmente do tema. Porém, por não terem como objeto de estudo a escolha do sistema de governo, nenhum desenvolve uma revisão detalhada do processo decisório, deixando várias "pontas soltas" e até mesmo contradições. Por ser um momento fundamental para a reestruturação institucional brasileira no processo de redemocratização, é relevante observar como se deu o jogo político na decisão do sistema de governo a ser implantando. Para isso, além de ser necessária a investigação de quais foram as motivações - normativas e de interesses - e argumentos dos atores políticos relevantes para a definição da questão, é fundamental abordar as condições específicas do processo decisório no ambiente Constituinte - pressões externas, regras regimentais devido a suas particularidades.

Ao estudar os debates da Constituinte em torno do fortalecimento do Poder Executivo, bem como sua relação com o Poder Legislativo, Limongi (2008) abre diversos pontos que podem ser explorados em trabalhos futuros. Segundo o autor, os trabalhos constituintes foram marcados por um amplo debate institucional. O debate público era dominado pela ideia de que a sorte do país estava atrelada de forma direta às opções institucionais a serem consagradas na Constituição. O sistema de governo a ser adotado ocupava o centro do debate, visto como um primeiro princípio do qual tudo o mais dependeria. Essa crença do peso que as instituições políticas teriam sobre a vida nacional seria uma herança do intenso debate presente no país desde meados dos anos cinquenta, época em que se iniciam questionamentos sobre a estrutura institucional adotada pelas constituições de 
1934 e 1946.

O debate era marcado com conclusões pessimistas acerca das instituições políticas brasileiras e sua potencialidade de gerar uma democracia. Além das ditas mazelas do presidencialismo estavam somadas ainda aquelas provenientes do multipartidarismo, do federalismo descentralizado e do bicameralismo, que levaria a um sistema político paralisado, envolto em crises explosivas que poderiam tirar os militares, mais uma vez, da caserna. Propostas no sentido da adoção do parlamentarismo ou de um sistema semipresidencialista foram arduamente defendidas por alguns grupos, mas não lograram êxito. Essas eram justificadas pelo temor de que, na presença de um Poder Legislativo fortalecido e de um contexto de alta fragmentação partidária, os presidentes brasileiros encontrassem obstáculos à criação de maiorias de apoio. Temia-se que, sob o presidencialismo, no qual impera o princípio da sobrevivência independente dos Poderes, o país ficasse exposto a permanentes crises de governabilidade e paralisia decisória (Souza, 2003).

Limongi também afirma que, com relação à forma de governo, havia plena consciência quanto à indefinição da tendência predominante no plenário. Os parlamentaristas vencem as primeiras batalhas nas comissões, mas sabiam que poderiam perder na decisão final em plenário. O texto, portanto, teria sido escrito nas primeiras etapas do processo constituinte, e os parlamentares teriam plena consciência de que a decisão em relação à forma de governo ainda estava pendente e seria definida apenas em plenário. Devido à sua centralidade no debate do período, sabia-se que o tema seria disputado e provocaria disputas intensas. As tentativas de acordo entre as partes envolvidas não prosperaram ou não puderam ser mantidas. As votações relacionadas à forma de governo sempre foram conturbadas e marcadas por forte polarização.

Neste debate era possível ver manifestações de constituintes que evidenciavam estar em jogo interesses de curto prazo, quando não imediatos, nas decisões relativas à forma de governo. Partidos seriam presidencialistas por terem um candidato forte à presidência, e outros seriam parlamentaristas por quererem atuar apenas no Congresso Nacional. Dessa forma, interesses partidários se expressariam na forma com que tratariam do tema.

Limongi trata de questões fundamentais e algumas delas podem ser aprofundadas: se 
o sistema de governo era tido como um primeiro princípio do qual tudo o mais dependeria, por que não se procurou defini-la primeiramente, ao invés de tomá-la como uma questão qualquer a ser decidida no final do processo, havendo plena consciência de que apenas em plenário é que se tomaria a decisão derradeira? Como as definições relativas à forma de governo foram epicentros causadores de instabilidade ocorrida durante o processo constituinte? Como e por que se deu a polarização nesta questão? Quais eram os grupos? Eram partidários? Estavam distribuídos em certo espectro ideológico? Algumas destas questões são levantadas e tentam ser respondidas por outros autores, mas não sem um bom grau de divergência entre eles.

Freitas, Moura e Medeiros (2009) argumentam como o debate sobre sistema de governo serviu de epicentro para maior reviravolta da Constituinte: o surgimento do Centrão , bloco suprapartidário que só se viabilizaria efetivamente enquanto um agrupamento minimamente coeso quando se alça à condição de garantidor do presidencialismo para o então Presidente da República, José Sarney. A ruptura regimental proposta pelo Centrão resultou, por um lado, das dificuldades que o antigo Regimento Interno impunha às modificações propostas em plenário ao projeto aprovado pela Comissão de Sistematização (ou seja, um problema procedimental) e, por outro, e mais especificamente, de uma demonstração de força e insatisfação do grupo conservador, que, ao lado de Sarney, posicionava-se firmemente no contexto dos debates que se estabeleciam sobre a forma de governo. Mudanças tão substantivas no Regimento Interno não teriam sido feitas caso o anteprojeto aprovado na Comissão de Sistematização não previsse o parlamentarismo. Estes são, segundo os autores, os elementos que aglutinaram o Centrão e alimentaram suas batalhas iniciais, ainda que não fossem suficientes para assegurar que o grupo emplacasse unilateralmente um projeto de Constituição.

No entanto, como o objetivo dos autores é explicitar, através do uso do W-Nominate, a posição dos atores relevantes do processo constituinte no espectro ideológico (esquerda e direita), eles se preocupam mais em analisar as diferenças ideológicas entre Centrão, Comissão de Sistematização e Plenário, do que em comprovar que o bloco suprapartidário efetivamente tinha em comum a reivindicação pela alteração do sistema de governo. Dessa 
forma, cabe-se questionar: esse grupo suprapartidário realmente possuía congruência em relação à adoção do presidencialismo, ou essa característica diz respeito a apenas à base governista de Sarney? A direita realmente tinha consenso em relação ao presidencialismo, ou novamente credita-se isso aos apoiadores de Sarney? A esquerda, que não fazia parte do Centrão, era consensualmente parlamentarista? Qual é a relação entre o espectro ideológico e a defesa de certo desenho institucional, se é que ela existe?

Lopes (2008) argumenta, ao analisar as votações finais da Constituinte, que excetuandose o tema do regime de governo, todos os demais temas essenciais da ordem pública foram decididos por maiorias consensuais, formadas por concessões mútuas entre todas ou as principais tendências da Assembleia. A trajetória política do regime de governo durante o processo constituinte teria conduzido a um resultado inesperado e indesejado por ambas as correntes, em virtude da inviabilização de concessões mútuas, cuja articulação, em outros temas da ordem pública, produziu um consenso sólido.

Para este autor, esta falta de consenso em torno do sistema de governo também estava presente no Centrão. Para ele, a unidade programática do grupo se restringia a conferir maior espaço ao mercado na ordem constitucional. Seria uma coalizão orientada por um consenso negativo sobre a ordem política a ser instaurada no país, contra excessos participativos na vida política e excessos obrigacionais à propriedade privada. Dessa forma, o Centrão não teria formado um consenso sobre o sistema de governo a ser adotado, preferindo inclusive, para a manutenção de sua unidade, que fosse o único tema a não ser objeto de emenda coletiva do grupo.

Lopes ainda identifica que, na votação em plenário, apenas os partidos de esquerda tinham posições consensuais em prol do presidencialismo (PDT e PT) ou do parlamentarismo (PC do B , PCB e PSB ). O tema dividia todos os outros partidos. Seus líderes anunciavam suas preferências pessoais, mas frisavam que a questão era aberta nas bancadas. Mais perguntas surgem: já que, aparentemente, não existe relação direta entre posição ideológica e apoio a certo sistema de governo, o que faria com que certos partidos apoiassem certo desenho institucional? Nos partidos que deixavam a questão em aberto, como os constituintes formulavam suas preferências e no que eram baseadas? 
A centralidade do debate acerca do sistema de governo foi tamanha que Simoni Junior, Silva e Souza (2009) afirmam que a pauta do sistema eleitoral foi relegada a um segundo plano devido a importância que as deliberações do sistema de Governo receberam, devido a proximidade das eleições presidenciais e os tropeços do governo José Sarney. Sendo o sistema de Governo a grande questão da Constituinte, não houve espaço para outras reformas que seriam desejadas no momento. Os reformistas teriam deixado de lado a reforma eleitoral para conquistar um maior apoio ao parlamentarismo. Muito provavelmente, acreditavam que se aprovado o parlamentarismo, seria possível alterar a legislação eleitoral por meio de Lei Complementar.

Outro fator que mostra a centralidade da discussão em torno do sistema de governo foi a presença de Sarney no debate, exercendo pressão aos trabalhos constituintes, por meio de sua estreita relação com os militares. Uma situação exemplar de sua pressão é relatada por Zarevucha (1994). Na véspera da decisão da Constituinte sobre o sistema de governo, os militares apoiaram a posição de Sarney e teria havido ameaças de golpe ao Congresso caso o parlamentarismo fosse aprovado. Por não ter existido qualquer reação de enfrentamento a esta ameaça, o artifício da intimidação teria dado resultado. Pela primeira vez desde o início dos trabalhos constituintes, todos os parlamentares estiveram presentes na votação, que teve como resultado 343 votos a favor do presidencialismo e 213 contrários. Cabe questionar, enfim, de que maneira se deu a influência de Sarney sobre a Constituinte, por meio mas também além da instrumentalização dos militares. Quem eram os constituintes que o apoiavam e por quê? Qual era o interesse de Sarney em manter o presidencialismo? Por que simplesmente não estabeleceu um acordo de que o regime só viesse a ser alterado após o fim de seu mandato? Na defesa do presidencialismo, seria possível dizer que Sarney defendia o interesse de algum grupo ou agia apenas por seu próprio interesse? Como outros constituintes percebiam a pressão de Sarney nos trabalhos da Assembleia? Por que os militares apoiavam Sarney e o presidencialismo?

Investigar como se deram os debates, embates e o jogo político em torno do sistema de governo se torna relevante devido à sua centralidade e importância no contexto da Constituinte. A pretensão é explorar a lacuna existente na literatura sobre o assunto, e 
analisar quais as linhas de força que, ao longo do processo constituinte, manifestaram-se a esse respeito, e quais os meios que foram vislumbrados para torná-los efetivos. Para isso, torna-se necessário identificar quais foram os atores relevantes, analisar suas preferências políticas, compreender a interação desenvolvida e as estratégias postas em prática, além de identificar fatores de natureza específica de Assembleias Constituintes que influenciaram o processo deliberativo em questão.

\section{Seção I - As mudanças institucionais de 1961/63}

A comparação entre os regimes democráticos de 1946 e 1988 foi útil para demonstrar as semelhanças e diferenças entre os sistemas políticos, especialmente a melhor performance do Executivo no segundo em relação ao primeiro deles. Os dois períodos propiciam também comparações em torno da escolha institucional sobre o sistema de governo, tema central deste trabalho. Refiro-me ao fato de que em 1961, devido à renúncia de Janio Quadros, foi instituído o parlamentarismo como solução de compromisso necessária a dar posse ao vice-presidente João Goulart. Desse momento até janeiro de 1963, quando foi realizado o Plebiscito sobre o sistema de governo, as forças políticas se posicionaram em torno da questão presidencialismo x parlamentarismo, levando à vitória popular final do primeiro em relação ao segundo. Trinta anos depois, em 1993, o país voltaria a decidir sobre as duas formas e o presidencialismo sairia vitorioso novamente. A comparação entre os dois processo pode ser útil para compreendermos que interesses e ideais parecem sustentar o presidencialismo entre nós, bem como alimentar a visão alternativa de que o parlamentarismo poderia ser melhor, se institucionalizado.

Quando comparamos o período de 1961/63 com o 1987/88, através do trabalho "Democracia ou Reformas" de Argelina Figueiredo (1993), encontramos algumas semelhanças que nos permitem verificar se fatores que influenciaram a decisão no regime anterior também teriam influenciado no processo de redefinição das instituições brasileiras durante nossa redemocratização. Figueiredo se utiliza de uma estratégia de pesquisa centrada na análise da conduta estratégica dos atores políticos de 1961/64, enfatizando seus interesses e percepções frente a situações históricas concretas. Tais condutas estariam sujeitas a 
constrangimentos estruturais, como o arcabouço político-institucional no qual os atores se encontram. Porém, os atores escolheriam as ações possíveis que acreditam levar a melhores resultados.

No que diz respeito ao sistema de governo, a autora afirma que a implementação do parlamentarismo foi resultado de uma ampla coalizão que visava preservar as instituições democráticas, uma solução encontrada para que Goulart pudesse tomar posse mesmo contra a vontade dos militares. Apesar da resistência da esquerda e de sua defesa pela sucessão constitucional estrita, o PSD e a UDN realizaram uma articulação com os militares em direção a uma solução que deu posse a Goulart, mas num sistema parlamentarista que reduziu suas funções presidenciais, transferidas ao primeiro Ministro.

Com a renúncia de Jânio Quadros, os ministros militares, que já haviam reagido às políticas de Goulart durante sua passagem pelo Ministério do Trabalho, elaboraram um manifesto em que expunham suas objeções com relação à posse de Jango. A relação de João Goulart com os sindicatos e líderes de esquerda, além de suas recentes viagens à União Soviética e à China, suscitavam a desconfiança dos militares quanto às disposições democráticas do futuro presidente. A manifestação dos militares visava conseguir do Legislativo uma decisão de veto à posse de Goulart, através da votação de um impeachment. No entanto, tanto grupos de esquerda que apoiavam as reformas de Jango, quanto grupos conservadores formaram uma coalizão contra a ruptura institucional.

Frente à crise que se configurava, com a possibilidade de que houvesse uma guerra civil devido às reações legalistas em diversos segmentos da sociedade, a implementação do parlamentarismo foi a solução encontrada ao impasse. Desde o início João Goulart manifestava-se contra a mudança do sistema de governo, porém a aceitou para que pudesse tomar posse como presidente. Uma minoria se manifestou contra o parlamentarismo, restringindo-se apenas a alguns segmentos de esquerda e a alguns parlamentaristas que se opunham à forma apressada como tal sistema estava sendo implementado. Aos partidos conservadores era interessante a alternativa proposta pois eles conseguiriam controlar o ímpeto reformista de Jango. Ao PSD havia dois outros motivos para apoiar o parlamentarismo: sendo o maior partido no Congresso, possuiria papel fundamental para a formação 
do gabinete, ampliando sua capacidade de influenciar as políticas do governo, e também por retirar Goulart da disputa presidencial de 1965 caso fosse mantida sua posse em 1961.

Acabou por ser adotado um parlamentarismo híbrido, não sem prejuízo da atuação eficaz e o funcionamento do governo. Goulart não poderia dissolver o Congresso, e ainda estava sujeito a sofrer impeachment devido a uma cláusula de "risco para a segurança nacional". O primeiro-ministro obteve os poderes executivos anteriormente atribuídos ao presidente, como a iniciativa de propor projetos e orçamento, decretar e executar intervenção federal. O presidente manteve alguns poderes que deveriam ser aprovados pelo primeiro-ministro e pelo ministro titular da pasta a que o assunto se referisse, tais como nomear os ministros, dispor de cargos públicos federais, vetar projetos de lei.

Dois fatores teriam contribuído para que o sistema parlamentarista não se institucionalizasse. O primeiro teria sido a formação de uma coalizão antiparlamentarista, atuando contra o regime. Através desta coalizão foram feitos ataques à legitimidade do sistema implementado, e inúmeras propostas de alteração constitucional no sentido de retorno ao presidencialismo. Goulart, desde sua posse, fazia campanha sobre a necessidade de que o povo decidisse sobre qual sistema deveria prevalecer. Com isso, esforçou-se para que o plebiscito fosse antecipado. Ao lado de Jango estavam a esquerda nacionalista favorável às reformas sociais propostas pelo presidente, mas também influentes figuras políticas do PSD e da UDN, interessados na conquista do cargo presidencial nas eleições de 1965, como Juscelino Kubitschek, Magalhães Pinto, Juraci Magalhães, Carlos Lacerda. A maioria dos governadores de estados temiam que o enfraquecimento do Executivo também fosse realizado no nível estadual, dificultando a implementação de suas políticas.

O segundo fator que teria contribuído para a não institucionalização do sistema parlamentarista teria sido a preocupação dos conservadores em ter um bom desempenho eleitoral em outubro de 1962. O PSD e a UDN teriam sofrido divisões internas a respeito desta questão, enfraquecendo o compromisso com o parlamentarismo. O principal problema seria o baixo apoio popular ao parlamentarismo. Mas outra preocupação seria mais importante, o controle sobre os cargos disponíveis na administração, papel ainda assumido por Goulart. O favorecimento ao partido do presidente, o PTB , , prejudicava 
os interesses fisiológicos dos partidos conservadores. O fato de estar fora do clientelismo oficial influenciaria negativamente o desempenho eleitoral da direita. Preocupados com sua sobrevivência política, com base em considerações de curto prazo e objetivos imediatistas, movidos pelo interesse em controlar fontes de clientelismo, um grande número de conservadores se mostrou disposto a retornar ao modelo presidencial. A defesa do parlamentarismo ficou restrita a poucos membros do PSD e da UDN.

Os interesses políticos envolvidos na definição do sistema de governo no período de 1961/63 podem ser sintetizados nos seguintes pontos:

- Presidente da República interessado no presidencialismo devido às prerrogativas de exercer maior poder efetivo.

- Esquerda reformista interessada no presidencialismo para conseguir por em prática suas propostas de maneira mais rápida.

- Candidatos fortes à presidência na próxima eleição seriam favoráveis ao presidencialismo, devido à perspectiva de assumirem o cargo com poderes mais amplos.

- Conservadores interessados no presidencialismo para manter fontes de clientelismo e fisiologismo.

- Conservadores interessados no parlamentarismo para impedir que reformas aceleradas fossem feitas, e devido à tendência de ter maior influência no âmbito parlamentar do que no eleitoral.

Através do trabalho de Figueiredo, podemos afirmar claramente que na ausência de um contexto favorável à deliberação, como o ambiente constituinte, a escolha institucional sobre o sistema de governo no período de 1961/63 foi marcada pelo pragmatismo político e interesses imediatos. Enquanto no primeiro momento instaurou-se o parlamentarismo com objetivo de preservar as instituições democráticas, no segundo momento tanto a esquerda quanto a direita eram favoráveis ao retorno ao presidencialismo por motivos e interesses políticos de curto prazo. Dentre as três hipóteses formuladas por Negretto (2009) citadas anteriormente, a que possui maior poder explicativo para este caso é a 
de que a mudança institucional foi orientada com base no interesse próprio e partidário. O desenho institucional escolhido foi resultado de cálculos estratégicos tanto de partidos de esquerda (interessados na implementação das reformas sociais propostas por Jango) quanto por partidos de direita (interessados em seu favorecimento para as eleições de 1965).

Retornar ao período de 1961/63, através da descrição das motivações individuais e partidárias feitas por Figueiredo, nos ajuda a entender como interesses podem influenciar a escolha institucional, inclusive de grupos ideologicamente distintos mas que convergem para uma mesma proposta, motivados por interesses partidários e de curto prazo. $\mathrm{Na}$ ausência de uma assembleia constituinte, a competição eleitoral e a disputa pela alocação imediata de poder predominam no cálculo em torno da definição do sistema de governo. Ambientes constituintes não estão imunes a essa dinâmica, mas propiciam melhores condições ao debate normativo sobre o melhor desenho institucional, tornando mais complexa a deliberação e a escolha final.

\section{Seção II - A Escolha do Sistema de Governo em 1987/88 à Luz de $1961 / 63$}

Ao evidenciar o pragmatismo dos atores envolvidos na definição institucional de 1961/63, o trabalho de Argelina Figueiredo nos ajuda a compreender o comportamento desses atores remodelados a um novo contexto. Durante a Assembleia Nacional Constituinte de 1987/88, há fortes indícios do mesmo tipo de relação entre defesa de um sistema de governo e interesses de curto prazo. No entanto, mesmo existindo permanência de pontos evidenciados por Figueiredo em relação aos interesses partidários presentes neste novo momento de redefinição institucional, o contexto é outro, exigindo que consideremos as três hipóteses formuladas por Negretto para que possamos compreender as escolhas institucionais neste novo momento histórico.

Assim como em 1961/63, podemos afirmar que em 1987/88 atores defenderam seu ponto de vista, seja em defesa do presidencialismo ou do parlamentarismo, por razões e interesses diversos. Durante o processo constituinte houve uma fragmentação de grupos 
e partidos em torno da questão do sistema de governo. Havia partidos diferentes, inclusive distantes entre si no espectro ideológico, que votaram de forma semelhante, tanto na frente parlamentarista quanto na presidencialista. Para compreendermos as razões dessa combinação heterodoxa de forças partidárias teremos que associar as três hipóteses apontadas por Negretto, isto é, a do legado histórico, a da imparcialidade e a do cálculo estratégico. Enquanto essa última, isoladamente, talvez seja suficiente para explicar as escolhas de 1961/63, apenas a combinação das três será capaz de explicar os principais fatores que marcaram as escolhas em 1987/88.

A hipótese da influência de forças precedentes pode ser demonstrada a partir da influência do papel Sarney e dos militares no processo constituinte. Como resultado de fortes elementos de continuidade na transição democrática - as mesmas regras eleitorais e sistema partidário anterior - Sarney exerceu grande pressão e se valeu de sua influência para fazer com que o presidencialismo fosse aprovado, juntamente com um mandato de 5 anos, para que pudesse se manter na Presidência da República com poderes mais efetivos. Para concretizar seus interesses, Sarney se associou aos conservadorese aos militares. Os primeiros estariam preocupados em manter o presidencialismo para assegurar a continuidade dos instrumentos de clientelismo e fisiologismo aos quais estariam habituados. As pressões de Sarney colaborariam neste ponto, pois faria uso da distribuição de recursos para incentivar o apoio deste grupo. Quanto aos militares, sua opção pelo presidencialismo tinha a ver com o entendimento, predominante no interior das forças armadas, de que o sistema presidencialista seria o mais propício a preservar a hierarquia da corporação e ao mesmo tempo a manutenção de seu papel moderador sobre o próprio sistema político.

A hipótese da imparcialidade guarda relação direta com o modus operandi instituído por uma constituinte. Diferentemente do que ocorreu em 1961/63, o ambiente deliberativo de 1987/88 foi mais favorável à emergência e ao peso de argumentos normativos, graças à maior liberdade de discussão e aos incentivos para se fazer escolhas de longo prazo, projetando desenhos institucionais com base em ideias e valores, e não apenas em interesses de curto prazo. Aqui poderíamos enquadrar os constituintes que se mostraram coesos em torno do parlamentarismo, como a esquerda parlamentarista (PC do B, PCB e PSB) e os 
dissidentes do PMDB , que formaram o PSDB no final do processo constituinte, já que para estes o cálculo estratégico de curto prazo não se sobrepôs ou tomou lugar de suas preferências normativas sobre o tema.

A última hipótese, relacionada ao interesse próprio e partidário também deve integrar a explicação. A adesão do PT e do PDT ao presidencialismo seria consequência do pragmatismo do momento, guiados pelos interesses imediatos e diante da possibilidade clara de chegarem à presidência da república, uma vez que estes dois partidos possuíam dois fortes concorrentes ao cargo, Lula e Brizola. Particularmente no caso do PT esse posicionamento estratégico conviveu durante algum tempo e ao final teve mesmo que se impor em relação a um grupo significativo de lideranças do partido que, no plano das ideias, chegou a defender o parlamentarismo.

Replicar e testar essas hipóteses serão os objetivos do próximo capítulo. Dessa forma, poderemos buscar compreender por quais motivos o presidencialismo foi mantido, mesmo quando acreditava-se que o sistema parlamentarista seria vitorioso. E também poderemos ter uma melhor compreensão sobre a origem do presidencialismo de coalizão. 


\section{Capítulo 3 - O Posicionamento dos Constituintes em Relação ao Sistema de Governo}

Com o argumento de que havia uma necessidade de se promover a participação de todos os parlamentares no processo constituinte (Souza, 2001; Pilatti, 2008), foi criado um regimento interno de formato descentralizado, pensado de forma que a Constituição fosse elaborada num processo "de baixo para cima". A descentralidade se deu na formação de oito comissões temáticas, compostas de sessenta e três membros cada, sendo cada uma delas subdivididas em três subcomissões, cada uma com cerca de vinte e um membros. O relator de cada subcomissão preparava um anteprojeto baseado em propostas de constituintes, sociedade civil em reuniões e audiências públicas. As subcomissões encaminhavam os relatórios aprovados internamente às suas respectivas comissões temáticas, que passam por um processo semelhante e enviam seus relatórios à Comissão de Sistematização, que propunha um anteprojeto de constituição a ser encaminhado ao plenário para, então, se elaborar um projeto de constituição.

A Constituinte, ao adotar esse modelo descentralizado, formalizou um processo em que, no limite, artigos aprovados por apenas seis integrantes de determinada subcomissão poderiam entrar no anteprojeto, de modo que, para retirá-los do texto, em plenário, fazia-se necessário uma maioria de 280 constituintes. Essa formulação foi a raiz do descontentamento que resultou na formação do bloco suprapartidário conhecido como Centrão ${ }^{1}$, e na reforma do regimento interno da Constituinte após quase um ano de iniciados os trabalhos.

Segundo Gomes (2006), uma das hipóteses para a formação do Centrão é a possibilidade de que as regras internas da Assembleia Nacional Constituinte, que garantiam aos líderes partidários a seleção dos integrantes das comissões, terem sido utilizadas estrategi-

\footnotetext{
${ }^{1}$ Já no final dos trabalhos da Comissão de Sistematização, articula -se uma maioria dos constituintes que foi denominada de "Centrão", um bloco suprapartidário de papel fundamental no processo constituinte. Seu objetivo foi mudar o regimento interno da Constituinte quando os pré-projetos de constituição apresentaram um viés progressista que não representaria as preferências do plenário, e também devido a dificuldade de alterá -los. O caráter progressista dos pré-projetos seria resultado do processo descentralizado da Constituinte e da falta de articulação inicial da direita, em contraste com a grande organização da esquerda. O governo acompanha e participa com simpatia da organização do grupo.
} 
camente pela ala mais à esquerda do PMDB que, guiada por Mário Covas, garantiu para si uma sobre-representação na Comissão de Sistematização e a nomeação dos relatores em comissões estratégicas. Isso teria se refletido no conteúdo substantivo do primeiro projeto de constituição, que foi considerado inaceitável pelo plenário. Mas como afirmam Freitas, Moura e Medeiros (2009), se o arcabouço institucional foi a justificativa para o levante do Centrão contra o regimento interno, o bloco suprapartidário se formou por objetivos práticos e pontuais, aglutinando indivíduos que, ainda que unidos à direita do espectro ideológico, tinham as mais diversas preferências. Alguns autores afirmam que um desses objetivos práticos e pontuais decisivos foi a questão do sistema de governo.

De fato, até a alteração do regimento interno, o presidencialismo sofria derrotas consecutivas. Antes da fase de Plenário era a proposta parlamentarista, ou semi-presidencialistas, que predominava. Apesar da figura do presidente da república não se extinguir, justificado pela tradição da política nacional e pela vontade popular de ter eleições diretas, o parlamento escolheria um primeiro ministro pra dividir os poderes com o presidente. Em alguns momentos predominava um primeiro ministro mais forte nos projetos, em outros os poderes eram mais divididos entre chefe de governo e chefe de Estado. Foi apenas em plenário, após a alteração do regimento interno, que o presidencialismo prevaleceu.

No projeto da Comissão de Sistematização, o sistema de governo que iria para votação no plenário era parlamentarista. O Chefe de Estado seria o Presidente da República, eleito de forma direta, em dois turnos caso necessário, por meio de sufráfio universal para um mandato de cinco anos. A nomeação do Primeiro-Ministro seria feita pelo Presidente, através da escolha de um dos membros do Congresso Nacional após consulta aos partidos políticos que formassem maioria na Câmara dos Deputados. Os ministros também seria escolhidos pelo Presidente através das indicações feitas pelo Primeiro-Ministro. O governo teria uma prazo de dez dias para apresentar seu programa de governo para ser submetido à Câmara. Caso houvesse rejeição, o Presidente nomearia outro Primeiro-Ministro. Caso houvesse uma segunda rejeição, os deputados poderiam eleger o Primeiro-Ministro. Se ainda assim não fosse escolhido um Primeiro-Ministro, o Presidente poderia dissolver a Câmara e convocar novas eleições. 
O Primeiro-Ministro exerceria seu governo respaldado pela confiança da Câmara dos Deputados. O voto de confiança do governo poderia ser solicitado pelo Primeiro-Ministro, dependendo da aprovação da maioria dos membros da Câmara. A Câmara poderia demonstrar sua falta de confiança no Primeiro-Ministro através de uma moção de censura de com apoio de um quinto dos deputados, que dependia da aprovação da maioria absoluta da Câmara. Tal medida poderia ser feita apenas seis meses após o estabelecimento do governo.

Com a alteração do regimento interno promovida pelo Centrão, a emenda Humberto Lucena, que propunha o presidencialismo, se tornou o status quo no qual os constituintes teriam que votar em plenário. Para sustentar o argumento de Limongi (2008) de que durante todo o processo constituinte a decisão sobre o sistema de governo estava aberta e incerta, apresentaremos os dados que o Datafolha divulgou na época, através de pesquisas de opinião com os próprios constituintes. Foram realizadas quatro pesquisas no total, entre fevereiro de 1987 e janeiro de 1988. A tabela 1 apresenta a proporção de apoiadores que os dois sistemas de governo tiveram nas pesquisas realizadas, e também na votação da Emenda Humberto Lucena.

Tabela 1: Pesquisas de opinião - Datafolha

\begin{tabular}{lccccc}
\hline & fev/87 & mai/87 & nov/87 & jan/88 & EHL \\
\hline \multirow{2}{*}{ Parlamentarismo } & 250 & 174 & 117 & 205 & 212 \\
& $48,26 \%$ & $36,55 \%$ & $25,49 \%$ & $40,28 \%$ & $37,90 \%$ \\
\hline \multirow{2}{*}{ Presidencialismo } & 212 & 171 & 310 & 277 & 344 \\
& $40,93 \%$ & $35,92 \%$ & $67,54 \%$ & $54,42 \%$ & $61,05 \%$ \\
\hline \multirow{2}{*}{ Outros } & 56 & 131 & 32 & 27 & 3 \\
& $10,81 \%$ & $27,53 \%$ & $6,97 \%$ & $5,30 \%$ & $0,50 \%$ \\
\hline Total & 518 & 476 & 459 & 509 & 559 \\
\hline
\end{tabular}

Como pode-se verificar, no início dos trabalhos constituintes, o parlamentarismo prevalecia com 48,26\% de apoio, contra 40,93\% de apoiadores do presidencialismo. Porém, na pesquisa seguinte realizada três meses depois, a situação encontra-se muito dividida, com uma diferença de menos de $1 \%$ entre os dois sistemas, e com um grande aumento de constituintes que se enquadram na categoria "outros", provavelmente por se manifestarem em favor de algum sistema misto. Seis meses depois, o quadro se inverte em relação ao começo da Constituinte. $67.54 \%$ dos constituintes entrevistados dizem preferir o presi- 
dencialismo, contra apenas $25,49 \%$ de parlamentaristas. Na pesquisa realizada dois meses depois, o quadro se equilibra, mas o presidencialismo se mantém a frente. Cabe notar que em uma questão disputada como essa, o tamanho da amostra influencia o resultado, já que a quantidade de constituintes entrevistados varia entre 459 e 518, considerando que no total 559 constituintes votaram na Emenda Humberto Lucena. Apesar de tal variação entre as pesquisas no número de entrevistados, apenas na segunda pesquisa, a mais apertada, que o tamanho da amostra poderia influenciar diretamente o resultado, sendo possível existir alguma reversão no quadro caso todos os constituintes fossem entrevistados.

Também é interessante analisar essas pesquisas separando os constituintes pelos partidos aos quais pertencem. A tabela 2 apresenta estes dados. A pesquisa de maio de 1987 não consta na tabela pois não permitia identificar o partido do entrevistado. Podemos observar que o PMDB oscila de uma pesquisa à outra até a votação da emenda Humberto Lucena, mas mantendo-se bem divido. Já o PFL sempre se posicionou majoritariamente em favor do presidencialismo, mas é notável como na primeira pesquisa a diferença é mínima, e nove meses depois a vantagem presidencialista é muito ampla. No PDS o parlamentarismo predominou apenas na primeira pesquisa, mas manteve-se com um considerável apoio no partido. É interessante notar também que os dois partidos de esquerda que foram praticamente unânimes em favor da emenda Humberto Lucena, PT e PDT, tiveram seus momentos de divisão frente à questão, o PT na primeira pesquisa e o PDT na última. Ocorre a mesma coisa com o PC do B, partido de esquerda parlamentarista. Já o PCB e PSB se mostraram parlamentaristas sempre.

A seguir, analisaremos os discursos feitos no período e a votação que decidiu o sistema de governo em plenário.

\section{Seção I - Análise dos Discursos}

Desde o início da fase de discussão e votação em plenário, dia 24/11/1987, até a definição do sistema de governo no dia 22/03/1988, foram feitas 177 manifestações a respeito do tema, por 103 constituintes, sendo os mais atuantes os parlamentares Victor Faccioni, com 12 discursos, e Aldo Arantes, com 7, ambos parlamentaristas. A tabela 
Tabela 2: Pesquisas de opinião - Datafolha - Partidos

\begin{tabular}{|c|c|c|c|c|c|}
\hline & & $\mathrm{fev} / 87$ & nov $/ 87$ & $\mathrm{jan} / 88$ & EHL \\
\hline \multirow{7}{*}{ PMDB } & \multirow{2}{*}{ Presidencialismo } & 97 & 136 & 115 & 153 \\
\hline & & $34,40 \%$ & $57,38 \%$ & $42,91 \%$ & $51,34 \%$ \\
\hline & \multirow{2}{*}{ Parlamentarismo } & 153 & 82 & 139 & 143 \\
\hline & & $54,26 \%$ & $34,60 \%$ & $51,87 \%$ & $47,99 \%$ \\
\hline & \multirow{2}{*}{ Outro } & 32 & & & \\
\hline & & $11,20 \%$ & $8,02 \%$ & $5,22 \%$ & $0,67 \%$ \\
\hline & Total & 282 & 237 & 268 & 298 \\
\hline \multirow{7}{*}{ PFL } & \multirow{2}{*}{ Presidencialismo } & 57 & 97 & 88 & 111 \\
\hline & & $47,11 \%$ & $85,84 \%$ & $72,73 \%$ & $82,84 \%$ \\
\hline & \multirow{2}{*}{ Parlamentarismo } & 55 & 13 & 26 & 23 \\
\hline & & $45,45 \%$ & $11,50 \%$ & $21,49 \%$ & $17,16 \%$ \\
\hline & \multirow{2}{*}{ Outro } & 9 & 3 & 7 & 0 \\
\hline & & $7,43 \%$ & $2,65 \%$ & $5,79 \%$ & $0 \%$ \\
\hline & Total & 121 & 113 & 121 & 134 \\
\hline \multirow{7}{*}{ PDS } & \multirow{2}{*}{ Presidencialismo } & 14 & 22 & 19 & 19 \\
\hline & & $38,89 \%$ & $59,46 \%$ & $54,29 \%$ & $55,88 \%$ \\
\hline & \multirow{2}{*}{ Parlamentarismo } & 17 & 9 & 13 & 15 \\
\hline & & $47,22 \%$ & $24,32 \%$ & $37,14 \%$ & $44,12 \%$ \\
\hline & \multirow{2}{*}{ Outro } & 5 & 6 & & 0 \\
\hline & & $13,90 \%$ & $16,22 \%$ & $8,58 \%$ & $0 \%$ \\
\hline & Total & 36 & 37 & 35 & 34 \\
\hline \multirow{7}{*}{$\mathrm{PT}$} & \multirow{2}{*}{ Presidencialismo } & 5 & 15 & 15 & 15 \\
\hline & & $38,46 \%$ & $93,75 \%$ & $93,75 \%$ & $93,75 \%$ \\
\hline & \multirow{2}{*}{ Parlamentarismo } & 5 & 1 & 1 & 0 \\
\hline & & $38,46 \%$ & $6,25 \%$ & $6,25 \%$ & $0 \%$ \\
\hline & \multirow{2}{*}{ Outro } & 3 & 0 & 0 & 1 \\
\hline & & $23,04 \%$ & $0 \%$ & $0 \%$ & $6,25 \%$ \\
\hline & Total & 13 & 16 & 16 & 16 \\
\hline \multirow{7}{*}{ PDT } & \multirow{2}{*}{ Presidencialismo } & 21 & 23 & 8 & 25 \\
\hline & & $84 \%$ & $92 \%$ & $47,06 \%$ & $96,15 \%$ \\
\hline & Parlamentarismo & 3 & 2 & 9 & 1 \\
\hline & г artamentuartsmo & $12 \%$ & $8 \%$ & $52,94 \%$ & $3,85 \%$ \\
\hline & Outro & 1 & 0 & 0 & 0 \\
\hline & & $4 \%$ & $0 \%$ & $0 \%$ & $0 \%$ \\
\hline & Total & 25 & 25 & 17 & 26 \\
\hline & Procidlociolicmo & 2 & 0 & 0 & 0 \\
\hline & Presidencialısmo & $40 \%$ & $0 \%$ & $0 \%$ & $0 \%$ \\
\hline & Parlamentarismo & 3 & 5 & 4 & 5 \\
\hline $\mathrm{PC}$ do $\mathrm{B}$ & Parlamentarısmo & $60 \%$ & $100 \%$ & $100 \%$ & $100 \%$ \\
\hline & Outro & 0 & 0 & 0 & 0 \\
\hline & Uutro & $0 \%$ & $0 \%$ & $0 \%$ & $0 \%$ \\
\hline & Total & 5 & 5 & 4 & 5 \\
\hline & Presidencialismo & 0 & 0 & 0 & 0 \\
\hline & Presidencianismo & $0 \%$ & $0 \%$ & $0 \%$ & $0 \%$ \\
\hline & Parlamentarismo & 3 & 1 & 5 & 3 \\
\hline PCB & & $100 \%$ & $100 \%$ & $100 \%$ & $100 \%$ \\
\hline & Outro & 0 & 0 & 0 & 0 \\
\hline & Uutro & $0 \%$ & $0 \%$ & $0 \%$ & $0 \%$ \\
\hline & Total & 3 & 1 & 5 & 3 \\
\hline & Presidencialismo & 0 & 0 & 0 & 0 \\
\hline & Fresidencialismo & $0 \%$ & $0 \%$ & $0 \%$ & $0 \%$ \\
\hline & Parlamentarismo & 1 & 0 & 3 & \\
\hline PSB & Parlamentarismo & $50 \%$ & $0 \%$ & $100 \%$ & $100 \%$ \\
\hline & Outro & 1 & 0 & 0 & 0 \\
\hline & Outro & $50 \%$ & $0 \%$ & $0 \%$ & $0 \%$ \\
\hline & Total & 2 & 0 & 3 & 6 \\
\hline
\end{tabular}


3 apresenta a quantidade de manifestações de acordo com o posicionamento que cada constituinte toma em seu discurso:

Tabela 3: Número de manifestações

\begin{tabular}{lrr}
\hline Sistema de Governo & No. & Col \% \\
\hline Parlamentarista & 93 & 52.54 \\
Presidencialista & 64 & 36.16 \\
Neutro & 20 & 11.3 \\
Total & 177 & 100.0 \\
\hline
\end{tabular}

Fonte: discursosplenario.dta

Fica clara a predominância da atuação de parlamentaristas neste período, com 52,54\% das manifestações, contra apenas 36,16\% de manifestações presidencialistas. Aqui foram consideradas manifestações neutras aquelas que não se posicionaram claramente em defesa de um dos sistemas de governo. A tabela 4 mostra a quantidade de manifestações sobre o sistema de governo agregado por partido, desconsiderando os posicionamentos neutros:

Tabela 4: Número de manifestações por partido

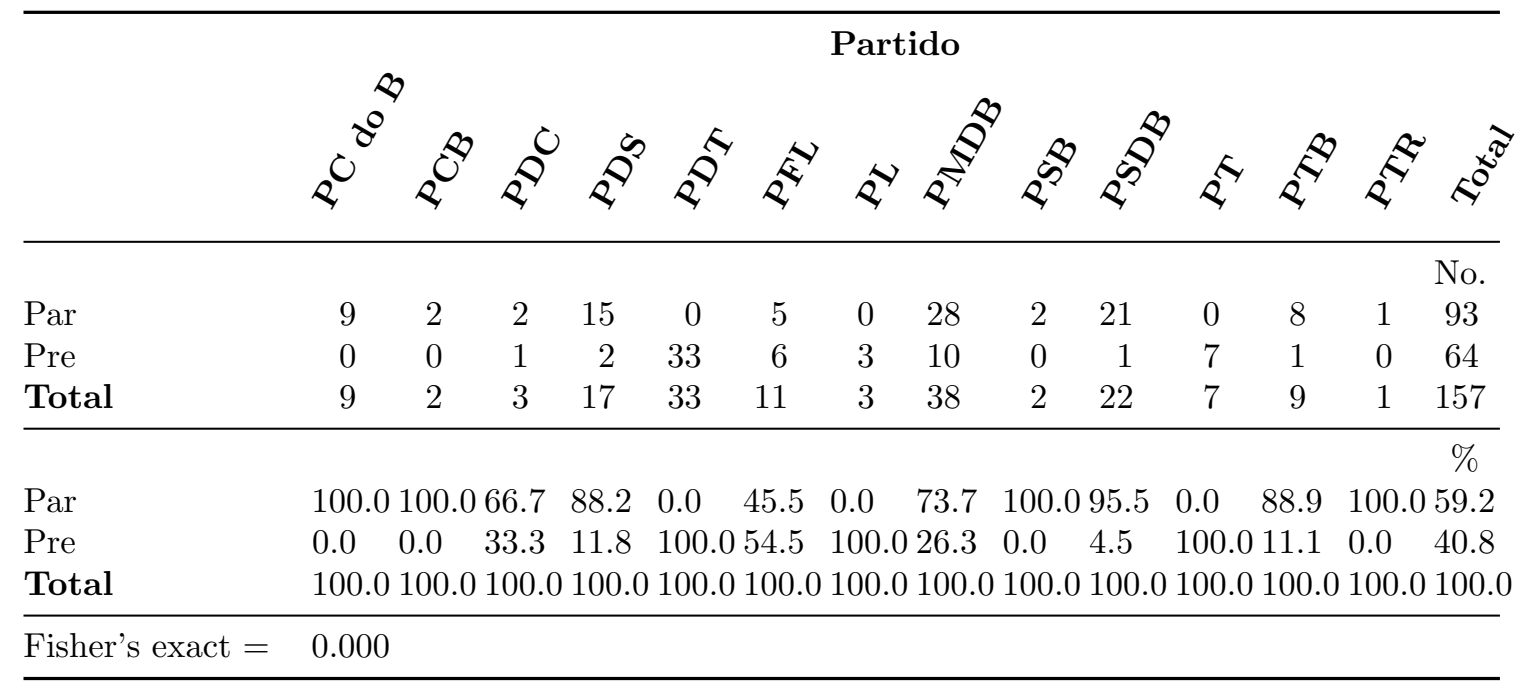

Fonte: discursosplenario.dta

De acordo com a tabela 4, verifica-se que os partidos que se manifestaram de forma unânime a favor do presidencialismo foram PDT, PL e PT, enquanto os unânimes a favor do parlamentarismo foram PC do B, PCB, PSB e PTR. Os partidos mais dividos em relação ao tema foram PDC e PFL. Os outros partidos, PDS, PSDB, PMDB e PTB 
foram majoritariamente parlamentaristas. Dessa forma é evidente não só o maior número de manifestações em favor do parlamentarismo, como também o fato de que foram principalmente os partidos de esquerda que fecharam questão em torno do assunto, sendo PT e PDT presidencialistas, e PC do B, PCB e PSB parlamentaristas. O PSDB ainda não havia se formado, mas a tabela já mostra que o parlamentarismo era um ponto em comum a este grupo dissidente do PMDB.

A tabela 5 mostra os principais temas abordados. Podemos observar que alguns temas foram mais explorados pelos parlamentaristas, como a questão do sistema partidário, a influência de Sarney no processo constituinte, a questão da instabilidade do regime democrático brasileiro, o fato de que o interesse de candidatos a presidência estaria influenciando o posicionamento de alguns partidos e as ameaças das forças armadas. Os principais tópicos abordados pelos presidencialistas foram: a questão da realização de um plebiscito caso o parlamentarismo vencesse, a influência do Centrão na decisão sobre o sistema de governo, o movimento das "Diretas Já" e a vontade popular de eleições diretas para eleger o chefe de governo. Dois temas foram abordados por ambas as correntes: o mandato presidencial de Sarney e a modernização do sistema político. A seguir, faremos uma exposição mais detalhada sobre como cada tema foi abordado.

\section{Sistema Partidário}

Na argumentação parlamentarista, um sistema de governo bem concebido seria condição necessária para que um país se desenvolva e consolide sua democracia. No caso brasileiro, o presidencialismo teria sido implementado sem nenhuma herança histórica com o sistema político nacional. Este sistema teria como característica central o personalismo, fator crucial que teria inviabilizado a estabilidade democrática no país. A figura de um líder partidário único seria tão forte no presidencialismo brasileiro que teria ocasionado crises partidárias, ou o fim dos próprios partidos na medida em que seus líderes e criadores morriam. Foram citados o PTB e PSD, frutos do empreendimento de Getúlio Vargas em se manter no poder, e também o PSP de Adhemar de Barros. Chegou-se até a afirmar que o PDT também acabaria quando Brizola morresse. 
Tabela 5: Temas das manifestações em plenário:

Em favor de:

Parlamentarismo Presidencialismo

Total

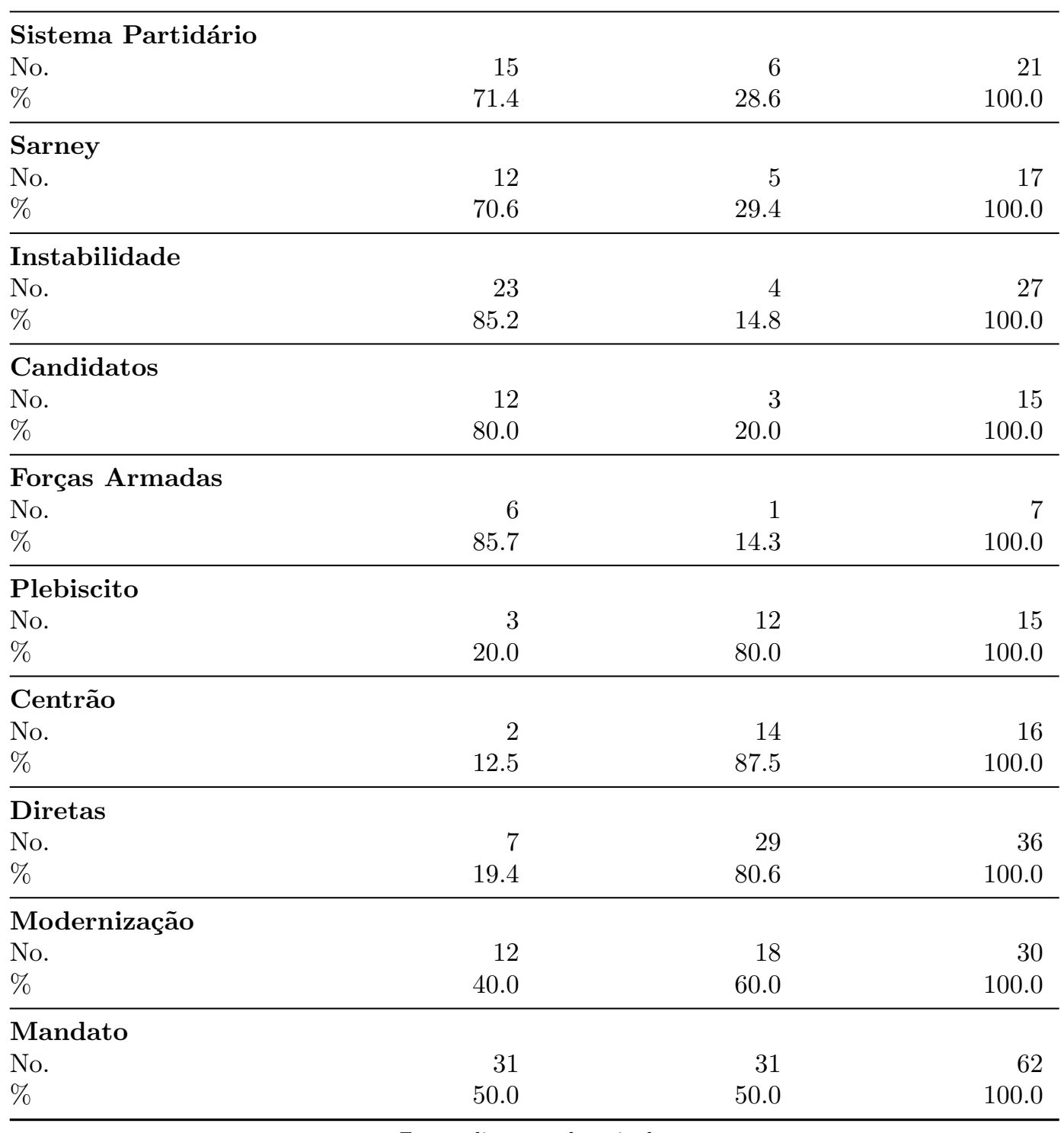

Fonte: discursosplenario.dta 
O parlamentarismo incentivaria o estabelecimento de partidos fortes e programáticos, remediando o fisiologismo e a desagregação partidária vigentes desde as primeiras experiências democráticas no Brasil até o período em questão. Isso se daria por uma maior responsabilização do legislativo na elaboração e implementação de políticas, pois a adoção do sistema parlamentarista faria com que o legislativo dividisse a responsabilidade do governo com o executivo, exigindo que o fisiologismo baseado na troca de favores não exista mais, fortalecendo a estruturação dos partidos doutrinariamente. Os parlamentaristas citaram com frequência a trajetória política de outros países, como Espanha, França, Grécia, Portugal e Itália, que não possuíam um sistema partidário bem consolidado quando adotaram o parlamentarismo, mas que acabaram por ter um um regime democrático bem estabelecido.

Os defensores do sistema presidencialista se defenderam através da pressuposição de que para a criação de um sistema parlamentarista é necessário já possuir um sistema partidário estabelecido para que o regime seja estável. Dessa forma, não seria o parlamentarismo o fator que favorece a consolidação dos partidos e da democracia, mas sim partidos bem consolidados que estabilizariam o regime democrático. O fato do país ainda não possuir partidos fortes seria um fator contrário a implementação do sistema parlamentarista.

Os presidencialistas também se defenderam da acusação de que é este sistema que produz um sistema partidário fraco. Para eles, o problema central seria a hipertrofia do Executivo e o papel secundário que o Legislativo teve durante o regime democrático brasileiro. A iniciativa do Congresso Nacional estaria sufocada e inibida. Dessa forma, os presidencialistas também eram críticos em relação ao regime vigente, propondo um novo equilíbrio de forças na divisão dos poderes. Sem o equilíbrio entre Executivo e Legislativo, não haveria consolidação do sistema partidário mesmo com a implementação do parlamentarismo, pois o fisiologismo continuaria com os partidos ainda interessados em sustentar o Governo em troca de recursos do poder.

Os parlamentaristas, no entanto, contra-argumentavam a ideia de um presidencialismo com Legislativo fortalecido, pois este favoreceria as crises institucionais no sentido de que 
o Legislativo teria mais poder de veto, impedindo e barrando políticas do Executivo mais do que de propondo soluções. Dessa forma, seria um sistema marcado mais pelo conflito do que pela cooperação. Para sustentar seu argumento, afirmavam que nos regimes democráticos anteriores o Legislativo possuía muito menos poder que o Executivo e já era responsabilizado pelas crises institucionais e inababilidade administrativa do Governo. Apenas equilibrar a distribuição de poderes, portanto, não seria suficiente para a estabilidade democrática. A solução seria mudar o sistema de governo para alterar a forma com que os poderes se relacionariam, não como os poderes seriam distribuídos.

\section{Instabilidade}

Constituintes parlamentaristas trouxeram à tona com frequência o tema da instabilidade política. Essa seria uma característica constante na história política do país, e o sistema presidencialista teria sido fundamental para ocasionar as crises políticas no Brasil. O presidencialismo seria a raiz da fragilidade democrática e causadora de fragilidades institucionais devido ao caráter personalista e imperial do nosso sistema político, permitindo que golpes de estado e regimes autoritários surgissem com certa facilidade. Para justificar essa visão, os parlamentaristas lançavam mão de longos discursos sobre a história política do país, desde a Proclamação da República até o Regime Militar, e argumentavam que era o presidencialismo que possibilitava a emergência de crises políticas.

Uma das características mais criticadas do presidencialismo foi a falta de mecanismos flexíveis capazes de fazer o regime se moldar à diferentes situações e crises que emergiriam ao longo do tempo. Com o prolongamento de crises, os presidentes em exercício perderiam o apoio popular e parlamentar, e a única solução democrática seria esperar terminar o mandato do presidente. Porém esta não seria a melhor forma de lidar com crises graves. Para solucioná-las poder-se-ia ainda abrir mão do regime democrático através de um golpe que destituiria o presidente da república, ou através de medidas autoritárias por meio das quais os presidentes reivindicariam mais poderes para lidar com a situação de crise. O parlamentarismo ajudaria a evitar crises por dois motivos. O primeiro seria incentivar os chefes do executivo a terem mais responsabilidade governamental, serem menos corruptos 
e menos centralizadores e autoritários, dialogando mais com o Congresso, uma vez que poderiam ser substituídos caso perdessem o apoio da maioria do parlamento. O segundo motivo seria a facilidade em retirar democraticamente o chefe do executivo do poder, sem a necessidade de golpes ou questionamentos legais. Dessa forma, a principal vantagem do parlamentarismo, segundo os constituintes, seria sua flexibilidade em lidar com situações de crise, pois teria mecanismos para substituir governantes sem agravar a situação com ameaças à continuidade de instituições democráticas, além de incentivar os governantes a não desviarem seu comportamento de forma a desagradar a opinião pública. Diversos parlamentaristas apontaram, inclusive, que esse recurso seria uma boa forma de manter os militares longe da tentação de tomar o poder novamente, pois jamais precisariam intervir em situações de crise.

Os presidencialistas pouco tocaram no assunto, e mal defenderam o presidencialismo das acusações de ter colaborado com a instabilidade na política brasileira. Mas apontaram que o parlamentarismo também está sujeito a instabilidades. A divisão do comando governamental poderia provocar uma inibição do poder de decisão. O parlamentarismo, assim como o presidencialismo, também estaria sujeito a se converter em regime ditatorial quando ocorrece uma centralização muito grande em torno de quem obtivesse mais poder. Citam como exemplo a Itália de Mussolini e a Alemanha de Hitler.

O único ponto defendido em relação ao presidencialismo foi de que neste sistema de governo não correria-se o risco, como poderia ocorrer no parlamentarismo, de se destituir o chefe de governo com frequência. Assim, o presidencialismo seria mais estável por dar segurança ao presidente, enquanto que o parlamentarismo estaria suscetível a uma maior insegurança e possibilidade de mais instabilidade. Esse argumento foi rebatido pelos parlamentaristas de duas formas. A primeira mais óbvia, de que a derrubada de um gabinete teria fundamento constitucional, e estaria dentro da ordem legal, enquanto que no presidencialismo não haveria possibilidade de retirar o governante do poder antes do prazo estabelecido, a não ser através de um golpe, rompendo a lei e a ordem social, gerando mais crises. A segunda forma de defesa foi observando a história política brasileira. Foi apontado que desde a implantação de nosso sistema presidencialista em 1889, a média de 
permanência no cargo dos ex-presidentes foi de apenas dois anos e dez meses.

\section{Candidatos}

Os constituintes parlamentaristas levantaram com mais frequência a questão de que a escolha do sistema de governo estaria vinculada aos interesses eleitorais imediatos dos partidos. Para este grupo, a manutenção do presidencialismo seria um golpe institucional. Isso seria resultado de uma visão imediatista e egoísta dos pequenos partidos de esquerda, inclusive com acusações de que Lula (do PT) e Brizola (do PDT) estariam buscando superar a fragilidade na esfera parlamentar de seus partidos, apelando para o personalismo carismático e messiânico para favorecer seus projetos eleitorais. Para os parlamentaristas, a esquerda presidencialista estaria tão "cega" em busca de seu objetivo que chegaria ao paradoxo de se unir com o governo Sarney e as Forças Armadas, inimigos históricos da esquerda, para concretizar a manutenção do presidencialismo.

Os presidencialistas quase não levantaram a questão, pois eram eles os acusados de interesse com argumentos mais contundentes. O argumento de defesa usado pela esquerda presidencialista foi de que o parlamentarismo era enxergado por eles como um "golpe branco", uma forma alternativa e ilegítima que as elites que estavam no poder procuravam para se manter no poder, visto que ainda teriam controle sobre o parlamento. Com isso, acusam parte do PMDB e do PFL de serem parlamentaristas devido a má imagem que Sarney possuía após a crise financeira, fazendo com que estes partidos perdessem prestígio no eleitorado, impossibilitando que surgisse um candidato presidencial. Dessa forma, a alteração para o parlamentarismo seria uma forma de se prevenir frente à vontade popular de renovação no poder.

\section{Sarney}

Sarney foi citado com frequência, direta e indiretamente, com acusações de intervir nas decisões da Constituinte, principalmente em torno da definição do sistema de governo e da duração de seu mandato. Uma das principais acusações que os parlamentaristas faziam ao Presidente da República foi de ter organizado a formação do Centrão, agre- 
gando a direita em torno da reforma regimental para que fosse possível alterar as decisões feitas pela Comissão de Sistematização. Além disso, também foi acusado de favorecer a concessão de emissoras de televisão e rádio, além de outros favores políticos como distribuição de cargos, para parlamentares que apoiassem as propostas presidencialista e de 5 anos de mandato. No dia da definição do sistema de governo, outra acusação foi de que governadores de alguns estados teriam pressionado constituintes de seu partido a votarem pelo presidencialismo, atendendo ao pedido de José Sarney.

Foi curiosa também a acusação de que Sarney teria influenciado Saulo Ramos, Consultor Geral da República, a publicar o livro "Assembleia Constituinte - Natureza Extensão e Limitação dos seus Poderes". Nele, o autor teria defendido a tese de que a Assembleia Nacional Constituinte teria poderes limitados, pois estaria condicionada à Constituição da qual derivou. Como a Constituinte havia sido convocada sob a égide da constituição militar, uma das limitações dos parlamentares seria a impossibilidade de alterar o sistema de governo.

Outra história em que fica evidente o poder de influência de Sarney sobre a Constituinte está na justificativa de Brandão Monteiro, do PDT, por ter expulsado dois parlamentares de seu partido. Os deputados João de Deus e Feres Nadar teriam tido posicionamentos opostos aos firmados pela bancada do PDT. A justificativa para a expulsão seria o fato de terem assinado a proposta do Centrão, votado a favor da alteração do regimento interno, e terem assinado as emendas substitutivas do Centrão. Em conversas com os constituintes antes da expulsão, Brandão Monteiro afirma que Feres Nadar teria se justificado de forma explícita que, por ter vindo do PDS, possuía vínculos estreitos com Sarney e que devia favores a ele. Com isso não poderia deixar de votar pelas pautas de interesse do Presidente. Este é um exemplo concreto de como Sarney conseguia de fato influenciar o comportamento de alguns constituintes.

\section{Forças Armadas}

Apesar de pouco frequente, é possível encontrar nos discursos constituintes afirmações que levam a uma relação entre as Forças Armadas e a defesa do sistema presidencialista. 
Segundo os parlamentaristas, o Ministro do Exército, General Leônidas Pires Gonçalves, teria afirmado publicamente que sua posição seria em favor do presidencialismo. Este teria não apenas afirmado defender tal sistema de governo, como também teria dito que não admitiria o parlamentarismo. A preferência dos militares pelo presidencialismo adviria do desejo de continuarem exercendo uma espécie de "tutela" sobre o regime democrático. Com o presidencialismo, as Forças Armadas manteriam prerrogativa de intervir na chefia do executivo em situações de crise, ou mesmo através de golpe caso fosse necessário destituir algum presidente, corrigindo "erros" do eleitorado em escolher políticos incompetentes, como já teria ocorrido em outras épocas segundo o próprio Ministro do Exército. Dessa forma, os militares continuariam pairando acima da Constituição.

\section{Plebiscito}

$\mathrm{O}$ argumento da necessidade de um plebiscito para que se alterasse o sistema de governo foi uma das principais pautas utilizadas pelos presidencialistas. Muitos salientavam a importância de discutir com o eleitorado uma mudança de tamanha magnitude. Uma justificativa recorrente para tal foi o fato de que durante a campanha para as eleições de 1986, ano em que os constituintes foram eleitos, não foi feito um debate sobre o tema. Muitos argumentavam que só o povo teria respaldo para promover tal mudança, pois somente estes seriam detentores do poder constituinte absoluto e originário, sendo então a única fonte de soberania para mudar o modelo instituído pelos fundadores do Estado. E para legitimar o discurso de que o povo seria resistente à mudança, o resultado do plebiscito de 1963 foi fartamente explorado. O resultado dessa consulta popular teria sido uma resposta frente ao golpe parlamentar, segundo os constituintes presidencialistas, que ocorreu em 1961. E mais ainda, este resultado seria uma manifestação "pura" de aprovação do presidencialismo, uma vez que o presidente em exercício na época, Jõao Goulart, não possuía prestígio à altura do resultado do plebiscito. Dessa forma, haveria uma ilegitimidade na implementação do parlamentarismo devido ao repúdio histórico que o povo teria feito a este sistema de governo. Aqui, novamente os presidencialistas defendiam que decidir pelo parlamentarismo seria uma forma da elite já estabelecida no poder se 
manter no governo, um golpe para acobertar uma crise econômica e de credibilidade política.

Poucos parlamentaristas se manifestaram em torno da ideia de um plebiscito. Houve quem concordasse com os presidencialistas de que manter Sarney no poder ao mesmo tempo em que se implantasse o parlamentarismo resultaria em uma grave crise política. Mas ao invés de propor uma consulta popular com relação a adoção do sistema de governo, foi proposto um plebiscito que se referisse ao tempo de mandato que restaria ao presidente, como alguns presidencialistas também propuseram. Houve também a preocupação de refutar a tese de que só o povo poderia decidir sobre a alteração do sistema de governo, pois não teria sentido uma Constituinte possuir soberania para propor mudanças de uma Constituição inteira com exceção desta questão. Inclusive haveria um paradoxo, segundo os parlamentaristas, pois quem defenderia isso seria justamente aqueles grupos que mais defenderiam a soberania da Constituinte. E ainda houve um parlamentarista que se preocupou com a possibilidade de um "buraco negro", uma possibilidade de não decisão quanto ao tema, e propôs a convocação de um plebiscito em 30 dias caso isso ocorresse.

\section{Diretas}

A pauta de eleições diretas para a escolha do chefe do Executivo esteve muito atrelada à questão anterior. Na defesa das eleições diretas, com frequência era mencionado o movimento das "Diretas Já" como reflexo da vontade popular em escolher o seu presidente de forma direta. Para os presidencialistas, seria um contrassenso frustrar as aspirações do eleitorado, mantendo o povo afastado das decisões do governo. A legitimidade do novo regime democrático só seria conquistada através da politização da população, e isso se daria apenas através da participação ativa do povo no momento que seria o ápice da cidadania política, a escolha de seus representantes de forma direta. A estabilidade e continuidade da transição democrática dependeria da incorporação da Nação no processo político, e nada seria mais mobilizador do que escolher o chefe de governo.

Algumas acusações aos parlamentaristas se repetem, como o fato de que a implementação do parlamentarismo e a instituição do voto indireto seria visto como resultado de 
conchavos e acertos das elites para se perpetuarem no poder com o retorno de uma espécie de Colégio Eleitoral dos tempos do regime militar. Seria instituir um mecanismo civil para reproduzir o governo ditatorial anterior. Inclusive acusavam Sarney de ter se associado aos militares para não deixar que a emenda Dante de Oliveira vencesse, impedindo que fosse instituido o voto direto já em 1984. Por isso, implementar o voto indireto era visto pelos presidencialistas como um novo golpe contra a soberania popular.

Os parlamentaristas pouco contra-argumentaram. Os que se manifestaram se mostraram favoráveis a eleição direta para Presidente da República. Houve até um reconhecimento de que eleição indireta para Presidente seria inviável no Brasil, devido a grande expectativa do povo em torno de eleições diretas imediatas. Porém nenhum esclareceu uma proposta concreta de como funcionaria tal sistema parlamentarista, ou como seria a distribuição de poderes entre Presidente e Primeiro Ministro. Mas a possibilidade de eleições indiretas foi descartada até pelos parlamentaristas.

\section{Centrão}

Apesar do fato de que foram mais constituintes presidencialistas que mencionaram o Centrão em seus discursos, o conteúdo crítico a este grupo suprapartidário também foi encontrado entre os parlamentaristas. A crítica ao Centrão estava associada ao seu vínculo com Sarney, e seus membros eram qualificados como pertencentes à extrema direita (ligados à UDR e UBE ) sendo assim resquício do regime autoritário. A criação do Centrão era vista como uma influência do governo no processo constituinte, com intenção de recuperar o mandato de 5 anos para Sarney e derrubar a proposta parlamentarista que saiu vitoriosa da Comissão de Sistematização. Foram feitas acusações ao presidente com afirmações de que, para angariar apoio a seus interesses, Sarney teria distribuído concessão de canais de rádio e televisão, verbas governamentais, cargos, obras e diversos outros favoreces políticos. Tudo em troca de assinaturas e votos em favor do projeto do Centrão. Houve também uma defesa no sentido de que o PMDB deveria se afastar do governo Sarney, uma vez que este teria perdido toda a confiança popular e se afastava do que o partido teria lutado em praça pública no período. 
Alguns integrantes do Centrão se manifestaram em defesa própria. A principal questão foi procurar desvincular o grupo das pautas defendidas por Sarney, a aprovação do presidencialismo e dos 5 anos de mandato. Segundo estes constituintes, no Centrão tais pontos não fariam parte dos assuntos discutidos internamente, e nenhum integrante estaria autorizado a falar em nome do Centrão com relação a tais questões.

\section{Modernização}

A palavra "moderno" esteve muito atrelada ao parlamentarismo nas palavras dos que defendiam este sistema. Apesar disso, praticamente não se encontram justificativas apresentadas pelos constituintes para entender o motivo. O máximo que foi dito sobre isso foi que o parlamentarismo foi fruto de uma evolução, e não uma pura invenção de intelectuais, pensadores, românticos ou acadêmicos. Tal sistema teria nascido na Inglaterra para conter o poder do rei, e permitir que o povo participasse no governo. A ideia de evolução aqui é tão forte que argumentou-se que haveria uma trajetória quase natural na evolução dos sistemas de governo. Primeiramente existira o Estado absolutista, que evoluiria para outras formas atenuadas de autoritarismo, tendo como o parlamentarismo o último estágio evolutivo do processo.

Para defender o caráter "moderno" do presidencialismo, os presidencialistas resgataram uma argumentação bastante utilizada por eles em outros tópicos: participação popular. Para estes, modernizar as instituições políticas brasileiras seria, em primeiro lugar, legitimá-las. Mas a legitimação do poder moderno necessariamente deveria passar pelo povo e sua participação no processo democrático. Ou seja, novamente resgata-se o tema da participação através da eleição direta para qualificar o presidencialismo. Outros constituintes defenderam que a emenda Humberto Lucena seria moderna pois redefiniria o papel do legislativo no processo decisório. Não apenas haveria um fortalecimento do legislativo através do aumento de atribuições ao Congresso controlando e fiscalizando os atos do governo, mas também cooperando e interagindo com o Poder Executivo. Mas na argumentação não especificou-se exatamente como o legislativo seria fortalecido ou como cooperaria com o executivo. 


\section{Mandato de Sarney}

Essa foi a questão mais levantada no período relacionado ao sistema de governo. Era muito frequente a manifestação do apoio a um sistema de governo juntamente com a manifestação do apoio ao tempo de mandato de Sarney. Um ponto interessante é que, até a votação da emenda Humberto Lucena, nos discursos em que tratavam sobre o sistema de governo, nenhum constituinte manifestou apoio a proposta de 5 anos de mandato para Sarney.

Presidencialistas e parlamentaristas acusavam a existência de constituintes que apoiavam os 5 anos de mandato para Sarney desde que isso assegurasse a vitória do parlamentarismo. Inclusive acusavam Ulysses Guimarães de estar negociando e fazendo pressão em torno de um maior tempo de mandato para Sarney para que o parlamentarismo vencesse. Muitos afirmavam que votar pelos 5 anos de mandato para Sarney seria ir contra a vontade popular, um golpe para fazer com que a elite se mantivesse no poder por mais um tempo, em uma tentativa de se reorganizar e recuperar o prestígio perdido pela má administração do presidente da república. As acusações de que o Centrão articulava acordos para a aprovação dos 5 anos também foi frequente. Fora da constituinte, os militares, a mídia e os setores empresariais também foram apontados como defensores de Sarney.

Parlamentaristas frisaram várias vezes que escolher parlamentarismo juntamente com um mandato de 5 anos para Sarney seria o pior cenário possível para a transição democrática. Prolongar o mandato de Sarney só faria com que a crise se acentuasse ainda mais, e quem levaria a culpa seria o novo sistema de governo, fazendo com que a população entrasse em descrença com a nova ordem institucional.

Uma preocupação recorrente era o fato de que a escolha pelo presidencialismo fortaleceria a tendência pelos 5 anos de mandato para Sarney. Como a emenda Humberto Lucena, que instituía o presidencialismo, seria votada antes da emenda que tratava do tempo de mandato de Sarney, alguns constituintes afirmavam que se essa primeira vitória fosse concedida a Sarney, muito facilmente ele conquistaria o tempo de mandato desejado posteriormente. Por este motivo, foram diversas as acusações de que PT e PDT estariam votando pelo presidencialismo e ajudando Sarney a dar um importante passo em direção 
à extensão de seu mandato.

Por todos esses motivos, alguns constituintes se manifestaram no sentido de que houvesse um esforço e esclarecimento de que as duas questões, sistema de governo e tempo de mandado de Sarney, fossem independentes e desvinculadas uma da outra. Tanto presidencialistas como parlamentaristas se manifestaram para que fosse dada atenção em separado para as duas pautas.

Pode-se verificar, dessa forma, que esta etapa do processo constituinte foi marcada pelo debate com a emergência de argumentos em defesa de cada um dos sistemas de governo. É neste momento que torna-se possível verificar o ambiente favorável à deliberação proporcionado pelo ambiente Constituinte, dando força ao papel das ideias na definição das instituições da época. Mesmo que alguns desses discursos estejam vinculados a um caráter pragmático, podemos identificar os motivos pelos quais os constituintes defendiam normativamente seus posicionamentos frente à questão do sistema de governo. Com o predomínio de manifestações parlamentaristas, surgiram preocupações com o desenvolvimento e consolidação do sistema partidário e do regime democrático e uma busca por maior valorização do legislativo, frente ao personalismo do Executivo. A virtude de uma mudança para o parlamentarismo seria a maior flexibilidade do regime frente a situações de crise, e dificultaria o surgimento destas pois forçaria um maior diálogo entre Legislativo e Executivo, e também afastaria a possibilidade de intervenção militar para reestabelecimento da ordem democrática. Já para os presidencialistas, o principal argumento utilizado foi o da soberania popular, com a participação direta do povo na escolha legítima do chefe do Executivo, demanda esta que vinha desde a campanha das "Diretas Já". No entanto, foram os presidencialistas que receberam acusações mais fortes de pragmatismo, tanto por estarem vinculados a Sarney (acusado diversas vezes de interferir no processo constituinte) quanto por terem candidatos fortes em seu partido para as eleições presidenciais seguintes, com Lula e Brizola. 


\section{Seção II - Votação da Emenda Humberto Lucena}

Os trabalhos da Comissão de Sistematização se encerraram no dia 24/11/1987, fazendo com que a etapa final de discussão e votação do projeto de Constituição em plenário se iniciasse. A questão do sistema de governo ainda estaria indefinida e sujeita a muita disputa política. Após quase 4 meses de discussão em plenário, a definição do sistema de governo foi votada, no dia 22/03/1988. A emenda Humberto Lucena propunha a manutenção do presidencialismo. A tabela 6 mostra o resultado final:

Tabela 6: Resultado da votação da Emenda Humberto Lucena

\begin{tabular}{lrr}
\hline Emenda Humberto Lucena & No. & Col \% \\
\hline Abstenção & 3 & 0.5 \\
Não & 212 & 37.9 \\
Sim & 344 & 61.5 \\
Total & 559 & 100.0 \\
\hline \multicolumn{3}{c}{ Fonte: Constituinte88.dta }
\end{tabular}

A tabela 6 mostra que o presidencialismo prevaleceu com $61,5 \%$ dos votos, enquanto o parlamentarismo obteve $37,9 \%$.

A tabela 7 mostra a distribuição dos votos por partido, incluindo o PSDB, que viria a ser criado ainda durante a Constituinte, posteriormente a esta votação:

Como pode-se verificar, foram os partidos progressistas que fecharam questão em torno do assunto. PSB, PCB e PC do B foram unanimemente parlamentaristas. Apenas PDT e PT foram presidencialistas de forma unânime (excetuando-se a abstenção de um petista). O PFL foi o único partido que foi presidencialista de forma não unânime, porém de forma majoritária. O futuro PSDB foi praticamente unânime em favor do parlamentarismo. O restante foi presidencialista de forma dividida.

Outra forma de ver a relação entre progressistas/conservadores e escolha do sistema de governo, é com a utilização das notas atribuídas pelo DIAP ao desempenho de cada um dos constituintes. Em "Quem foi Quem na Constituinte"(1988), o Departamento Intersindical de Assessoria Parlamentar elaborou um trabalho com o objetivo de classificar quais seriam os constituintes mais progressistas, analisando como cada um deles votou 
Tabela 7: Votação da Emenda Humberto Lucena por partido

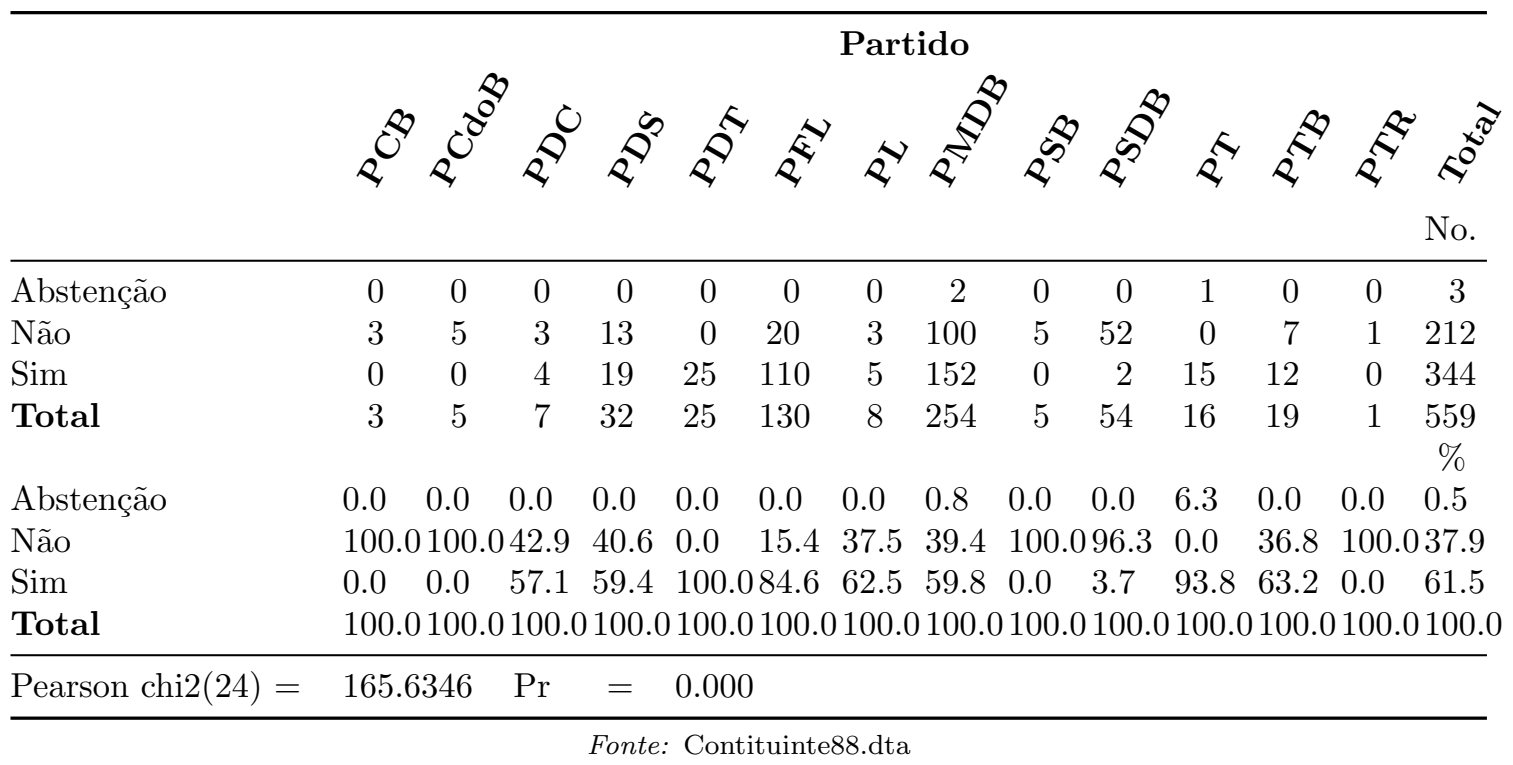

em questões de interesse para a classe trabalhadora. Dessa forma, o DIAP atribuiu notas aos constituintes de acordo com a avaliação de seu desempenho em votações que diziam respeito a direitos sociais e trabalhistas. A tabela 8 mostra a relação entre a votação na emenda presidencialista Humberto Lucena e as notas atribuídas pelo DIAP:

Tabela 8: Votação da Emenda Humberto Lucena por nota do DIAP

\begin{tabular}{|c|c|c|c|c|c|c|}
\hline & \multicolumn{6}{|c|}{ Nota DIAP } \\
\hline & $0^{\sigma^{2}}$ & $\begin{array}{l}<\theta^{0} \\
v^{2} \\
v^{2}\end{array}$ & $\hat{\sigma}_{0}^{2}$ & $\wedge^{\stackrel{9}{\sigma}}$ & के & $\hat{\sigma}^{x}$ \\
\hline & & & & & & No. \\
\hline Abstenção & 1 & 0 & 0 & 1 & 1 & 3 \\
\hline Não & 17 & 33 & 68 & 93 & 1 & 212 \\
\hline Sim & 144 & 75 & 56 & 62 & 1 & 338 \\
\hline Total & 162 & 108 & 124 & 156 & 3 & 553 \\
\hline & & & & & & $\%$ \\
\hline Abstenção & 0.6 & 0.0 & 0.0 & 0.6 & 33.3 & 0.5 \\
\hline Não & 10.5 & 30.6 & 54.8 & 59.6 & 33.3 & 38.3 \\
\hline Sim & 88.9 & 69.4 & 45.2 & 39.7 & 33.3 & 61.1 \\
\hline Total & 100.0 & 100.0 & 100.0 & 100.0 & 100.0 & 100.0 \\
\hline Fisher's exact $=$ & 0.000 & & & & & \\
\hline
\end{tabular}

A tabela indica a tendência de que os constituintes mais progressistas (aqueles que 
votaram em maior consonância em favor da ampliação de direitos sociais e trabalhistas) votaram contra a emenda Humberto Lucena, ou seja, foram contra o presidencialismo. É bem clara a relação inversa entre notas do DIAP e porcentagem de apoio ao presidencialismo. É notável também o fato de que o parlamentarismo prevaleceu, ainda que de forma dividida, entre os constituintes com nota superior a 5, enquanto o presidencialismo foi quase unânime entre os constituintes com nota inferior a 2,5. Foi entre os constituintes com menor nota que o presidencialismo obteve apoio com diferença considerável em relação ao parlamentarismo.

Também podemos verificar como foi o apoio dado à proposta presidencialista no Centrão. Aqui encontra-se o problema de definir quem fazia parte deste grupo suprapartidário, uma vez que critérios diversos podem ser adotados. Apresentamos nas tabelas abaixo três critérios utilizados pela literatura para identificar quem fez parte do Centrão: 1) baseado no trabalho do DIAP, que identificou os parlamentares que faziam parte do Centrão; 2) baseado no site da Câmara dos Deputados, com as informações biográficas de cada constituinte; 3) baseado na votação da emenda No. 1 substitutiva ao Regimento Interno da Câmara dos Deputados, que promoveu a alteração do regimento interno, e que pode ser considerada a primeira deliberação da qual o "Centrão" saiu vencedor na Assembléia Constituinte, demonstrando sua força política.

Na tabela 9 verifica-se que, em qualquer dos critérios utilizados, o presidencialismo obteve maior apoio entre aqueles que pertenciam ao grupo do Centrão. Na definição do Centrão de acordo com a votação na emenda No 1 foi necessário incluir aqueles que acabaram por não votar, pois Mário Covas comandou uma tentativa de obstrução da votação, reduzindo o número de votantes. Baseado neste critério 69,2\% dos que votaram na emenda presidencialista faziam parte do Centrão, enquanto 74,5\% dos que rejeitaram a emenda fizeram parte da tentativa de obstrução. Com base nos dados do DIAP, a proporção de presidencialistas que faziam parte do Centrão diminui para 53,2\%, mas a porcentagem dos parlamentaristas que não faziam parte do Centrão aumenta para 86,3\%. Já no último critério, o das biografias que constam no site da Câmara dos Deputados, a maioria que teria votado na emenda presidencialista, $68 \%$ seria de não-integrantes do 
Tabela 9: Votação da Emenda Humberto Lucena pelo Centrão

\begin{tabular}{|c|c|c|c|c|}
\hline & \multicolumn{3}{|c|}{ Emenda Humberto Lucena } & \multirow[b]{2}{*}{ Total } \\
\hline & Abstenção & Não & Sim & \\
\hline \multicolumn{5}{|l|}{ Emenda No. 1} \\
\hline Abstenção & 1 & 1 & 2 & 4 \\
\hline Não & 0 & 7 & 7 & 14 \\
\hline Sim & 1 & 46 & 238 & 285 \\
\hline Não votou & 1 & 158 & 97 & 256 \\
\hline Total & 3 & 212 & 344 & 559 \\
\hline Abstenção & $33.3 \%$ & $0.5 \%$ & $0.6 \%$ & $0.7 \%$ \\
\hline Não & $0.0 \%$ & $3.3 \%$ & $2.0 \%$ & $2.5 \%$ \\
\hline Sim & $33.3 \%$ & $21.7 \%$ & $69.2 \%$ & $51.0 \%$ \\
\hline Não votou & $33.3 \%$ & $74.5 \%$ & $28.2 \%$ & $45.8 \%$ \\
\hline Total & $100.0 \%$ & $100.0 \%$ & $100.0 \%$ & $100.0 \%$ \\
\hline \multicolumn{5}{|l|}{ Diap $\backslash$ Centrao } \\
\hline Não & 2 & 183 & 161 & 346 \\
\hline Sim & 1 & 29 & 183 & 213 \\
\hline Total & 3 & 212 & 344 & 559 \\
\hline Não & $66.7 \%$ & $86.3 \%$ & $46.8 \%$ & $61.9 \%$ \\
\hline Sim & $33.3 \%$ & $13.7 \%$ & $53.2 \%$ & $38.1 \%$ \\
\hline Total & $100.0 \%$ & $100.0 \%$ & $100.0 \%$ & $100.0 \%$ \\
\hline \multicolumn{5}{|l|}{$\mathrm{CD} \backslash$ Centrao } \\
\hline Não & 3 & 199 & 234 & 436 \\
\hline Sim & 0 & 13 & 110 & 123 \\
\hline Total & 3 & 212 & 344 & 559 \\
\hline Não & $100.0 \%$ & $93.9 \%$ & $68.0 \%$ & $78.0 \%$ \\
\hline Sim & $0.0 \%$ & $6.1 \%$ & $32.0 \%$ & $22.0 \%$ \\
\hline Total & $100.0 \%$ & $100.0 \%$ & $100.0 \%$ & $100.0 \%$ \\
\hline Fisher's exact $=$ & 0.000 & & & \\
\hline
\end{tabular}

Centrão. Porém a rejeição a emenda aumenta ainda mais entre os Constituintes que não faziam parte do Centrão, agora em 93,\%. Fica claro, portanto, que os parlamentaristas predominantemente não faziam parte do Centrão, enquanto os presidencialistas tendiam a fazer parte deste grupo, em maior ou menor proporção dependendo do critério utilizado.

Pode-se observar que o número de membros do Centrão varia bastante entre os três critérios, de 123 a 285 parlamentares. Na tabela 10, utilizaremos um cruzamento destas três fontes, para obtermos um número de constituintes que em algum momento foi julgado como integrante do Centrão. Dessa forma obtem-se um total de 306 constituintes. Na tabela 10 apresentaremos o apoio que a emenda Humberto Lucena recebeu entre diversos 
grupos suprapartidários:

Tabela 10: Votação da Emenda Humberto Lucena por grupos suprapartidários

\begin{tabular}{|c|c|c|c|c|c|}
\hline & & Grup & Supraparti & lários & \\
\hline & Centrao & $\begin{array}{r}\text { Direita nao } \\
\text { Centrao }\end{array}$ & Esquerda & $\begin{array}{r}\text { PMDB nao } \\
\text { Centrao }\end{array}$ & Total \\
\hline Abstenção & 1 & 0 & 1 & 1 & 3 \\
\hline Não & 51 & 18 & 15 & 128 & 212 \\
\hline Sim & 254 & 14 & 39 & 37 & 344 \\
\hline Total & 306 & 32 & 55 & 166 & 559 \\
\hline Abstencão & $0.3 \%$ & $0.0 \%$ & $1.8 \%$ & $0.6 \%$ & $\begin{array}{r}\% \\
0.5 \%\end{array}$ \\
\hline Não & $16.7 \%$ & $56.3 \%$ & $27.3 \%$ & $77.1 \%$ & $37.9 \%$ \\
\hline Sim & $83.0 \%$ & $43.8 \%$ & $70.9 \%$ & $22.3 \%$ & $61.5 \%$ \\
\hline Total & $100.0 \%$ & $100.0 \%$ & $100.0 \%$ & $100.0 \%$ & $100.0 \%$ \\
\hline Abstencão & $33.3 \%$ & $0.0 \%$ & $33.3 \%$ & $33.3 \%$ & $\begin{array}{r}\% \\
100.0 \%\end{array}$ \\
\hline Não & $24.1 \%$ & $8.5 \%$ & $7.1 \%$ & $60.4 \%$ & $100.0 \%$ \\
\hline Sim & $73.8 \%$ & $4.1 \%$ & $11.3 \%$ & $10.8 \%$ & $100.0 \%$ \\
\hline Total & $54.7 \%$ & $5.7 \%$ & $9.8 \%$ & $29.7 \%$ & $100.0 \%$ \\
\hline Fisher's exact $=$ & 0.000 & & & & \\
\hline
\end{tabular}

Fonte: Contituinte88.dta

Dividindo-se a Constituinte entre estes grupos, nota-se a importância do Centrão na definição do sistema de governo. 73,8\% dos presidencialistas faziam parte do Centrão, sendo que $83 \%$ dos membros deste grupo votaram a favor da emenda Humberto Lucena. Não apenas este grupo era majoritariamente presidencialista como também teve um peso muito grande na decisão em relação ao presidencialismo. É curioso notar que a direita que não fazia parte do Centrão estava dividida em torno do tema, e que a esquerda foi majoritariamente presidencialista. Outra informação interessante da tabela é sobre o comportamento do PMDB que não fez parte do Centrão. 77,1\% deste grupo foi contra o presidencialismo, tendo mobilizado $60,4 \%$ dos votos em favor do parlamentarismo.

Outra forma interessante de dividir a Constituinte é entre ex-arenistas e ex-MDBistas. Parte da literatura que analisa as votações deste período (Kinzo, 1990; Madeira, 2011) afirma que a filiação partidária do período do regime militar poderia influenciar bastante no processo decisório da Constituinte. Segundo estes autores, era de se esperar que houvesse certa coerência dos constituintes remanescentes de ambos os partidos militares com 
suas antigas legendas mensurada pela consistência ideológica de suas posições. Por estarem dispersos em diversos partidos, os ex-MDBistas concentrados no PMDB e partidos à esquerda deste, e os ex-arenistas distribuídos em todos os outros partidos com exceção do PT, torna-se relevante verificar se realmente existiu certa coerência entre estes dois grupos. Sendo assim, a tabela 11 apresenta o apoio à emenda Humberto Lucena agrupado de acordo com o partido ao qual os constituintes faziam parte durante o regime militar:

Tabela 11: Votação da Emenda Humberto Lucena por partidos do regime militar

\begin{tabular}{lrrr}
\hline & ARENA & MDB & Total \\
& & & 1 \\
\hline Abstenção & 0 & 1 & 139 \\
Não & 41 & 98 & 225 \\
Sim & 139 & 86 & 332 \\
Total & 180 & 185 & Col\% \\
\hline & & & $0.27 \%$ \\
Abstenção & $0.0 \%$ & $0.54 \%$ & $38.8 \%$ \\
Não & $22.78 \%$ & $52.97 \%$ & $61.64 \%$ \\
Sim & $77.22 \%$ & $46.49 \%$ & $100.0 \%$ \\
Total & $100.0 \%$ & $100.0 \%$ & Row\% \\
\hline & & & $100.0 \%$ \\
Abstenção & $0.0 \%$ & $100.0 \%$ & $100.0 \%$ \\
Não & $29.5 \%$ & $70.5 \%$ & $100.0 \%$ \\
Sim & $61.78 \%$ & $38.22 \%$ & \\
Total & $49.32 \%$ & $50.68 \%$ & \\
\hline Fisher's exact $=$ & 0.000 & Fonte: Contituinte 88 .dta \\
\hline
\end{tabular}

Nota-se que a antiga ARENA foi majoritariamente presidencialista, com 77,22\% dos votos favoráveis a emenda Humberto Lucena. Esse grupo foi responsável por 60,5\% dos votos favoráveis ao presidencalismo. O MDB se dividiu quanto à questão do sistema de governo, sendo ligeiramente favorável ao parlamentarismo. E foi este grupo que angariou $70,5 \%$ dos votos em favor do parlamentarismo.

Ainda com relação à análise das votações em plenário, podemos lançar mão do uso do W-NOMINATE para vermos a distribuição espacial dos constituintes, controlando por partido, pertencimento ao Centrão e posicionamento em relação a emenda Humberto Lucena. O W-Nominate é um método estatístico criado por Poole e Rosenthal (1985; 1991), baseado na teoria espacial do voto, que estima pontos ideais de legisladores e os repre- 
Gráfico 1: Dispersão ideológica entre membros do plenário - Partidos

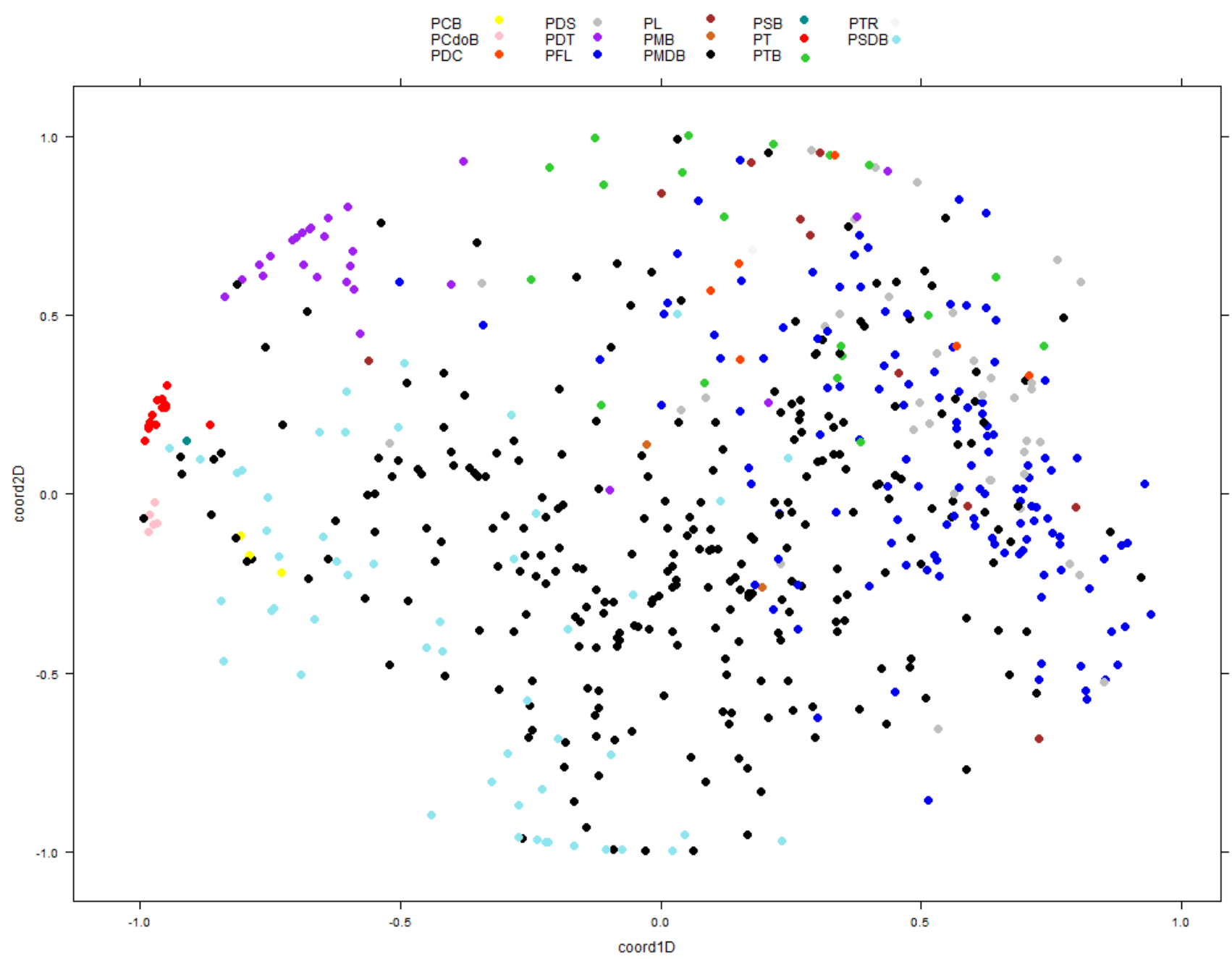

senta em coordenadas espaciais. Dessa forma, ao representar as preferências individuais e políticas como um ponto em um espaço, podemos verificar clivagens entre os constituintes e a distribuição de suas preferências. Este tipo de estimação estatística foi utilizado na Ciência Política brasileira para analisar a Câmara dos Deputados Leoni (2002); Zucco Jr (2009), a Assembleia Nacional Constituinte de 1987-88 Medeiros (2013); Freitas, Moura e Medeiros (2009) e o STF Ferreira (2013).

O gráfico 1 mostra a distribuição espacial dos constituintes separados por partidos, a partir dos votos feitos em plenário:

Nota-se que na primeira dimensão, na coordenada 1, os partidos se distribuem de forma coerente entre esquerda e direita no espectro ideológico. Os partidos de esquerda aparecem próximos e ao lado esquerdo do gráfico, os partidos mais heterogêneos aparecem 
Gráfico 2: Dispersão ideológica entre membros do plenário - Centrão

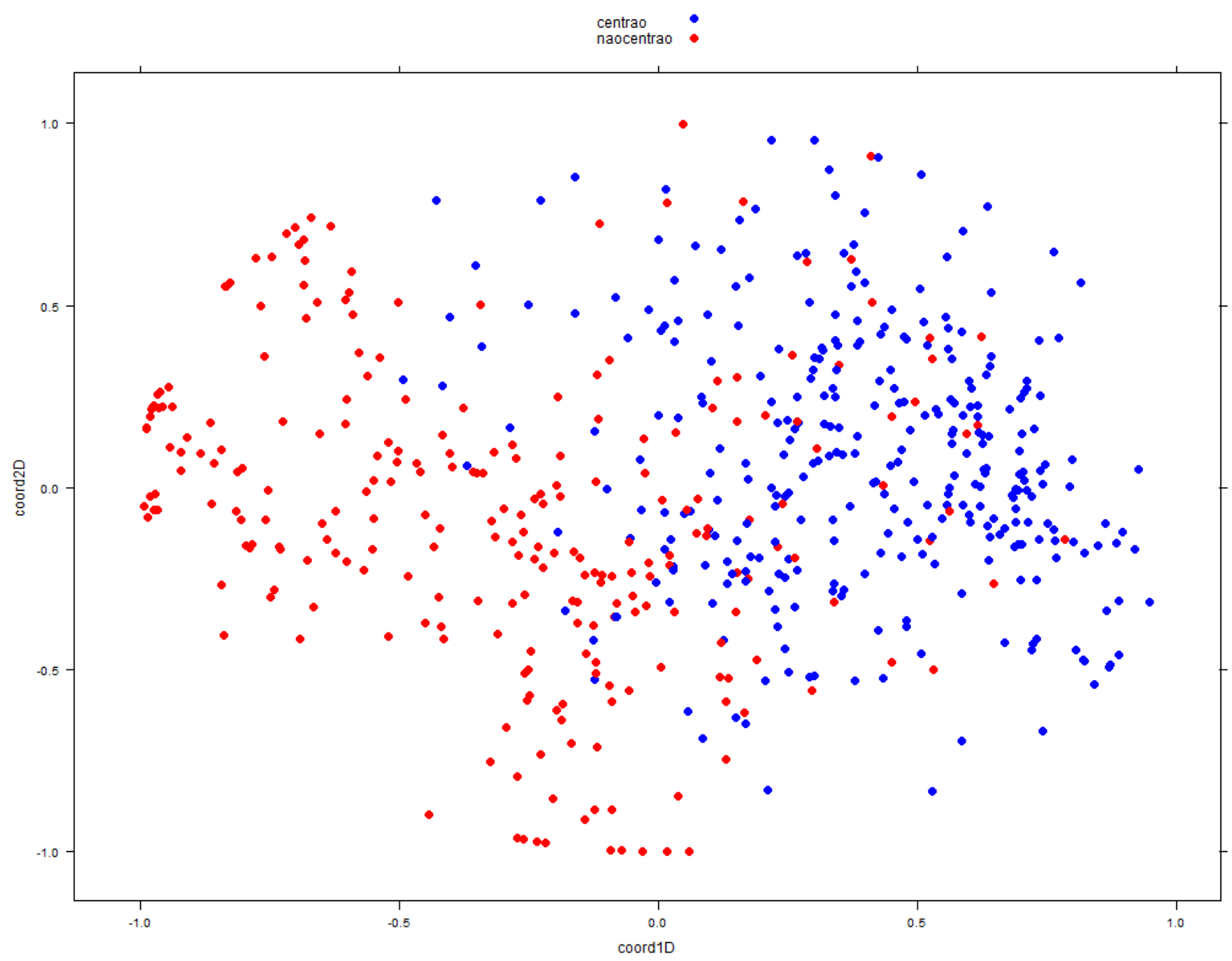

dispersos por todo o gráfico, e os partidos de direita aparecem ao lado direito da imagem. Dessa forma, podemos estar mais seguros de que a distribuição dos constituintes se dá em relação ao espectro ideológico, deixando claro que havia uma distinção entre esquerda e direita. O gráfico 2 mostra esta mesma dispersão, porém destacando o pertencimento ou não ao Centrão:

Como era de se esperar, o gráfico mostra que os constituintes que pertenciam ao Centrão estavam mais concentrados à direita do espectro partidário, correspondente à agenda mais conservadora. Agora, tendo uma noção de onde os partidos e o Centrão se posicionam no espectro ideológico, segundo o W-NOMINATE, apresentaremos o gráfico 3 com a divisão entre aqueles que apoiaram a emenda Humberto Lucena e os que foram contra: 
Gráfico 3: Dispersão ideológica entre membros do plenário - Emenda Humberto Lucena

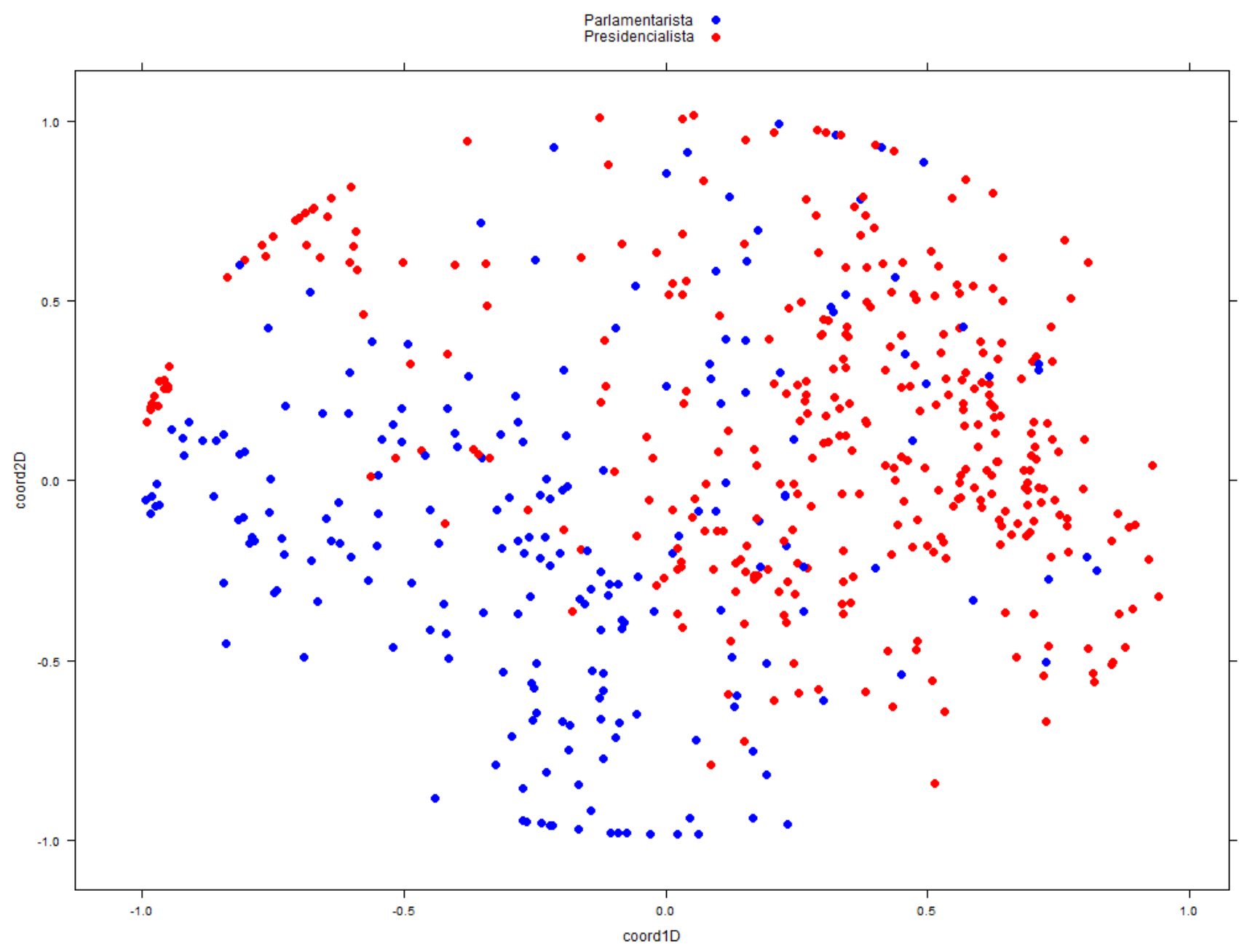

Neste gráfico observa-se que o predomínio de presidencialistas se dá ao lado direito do espectro ideológico, apesar de estar um pouco disperso do lado esquerdo também (devido aos votos presidencialistas do PT e PDT), enquanto os parlamentaristas se concentram na esquerda. Podemos comparar a dispersão ideológica entre os grupos do plenário através de boxplots, para podermos ter uma referência melhor do "median voter" e da distribuição da maioria dos integrantes de cada grupo. Os gráficos 4, 5, 6 e 7 mostram boxplots com a representação da dispersão ideológica do plenário, dos partidos, do Centrão e dos parlamentaristas e presidencialistas:

Quanto mais abaixo no gráfico estiver, mais localizado à esquerda do espectro ideológico o grupo estará. Assim, podemos verificar que o plenário possui uma certa tendência conservadora, com a maioria e a média dos constituintes presentes na parte superior do 
Gráfico 4: Boxplot - Dispersão ideológica

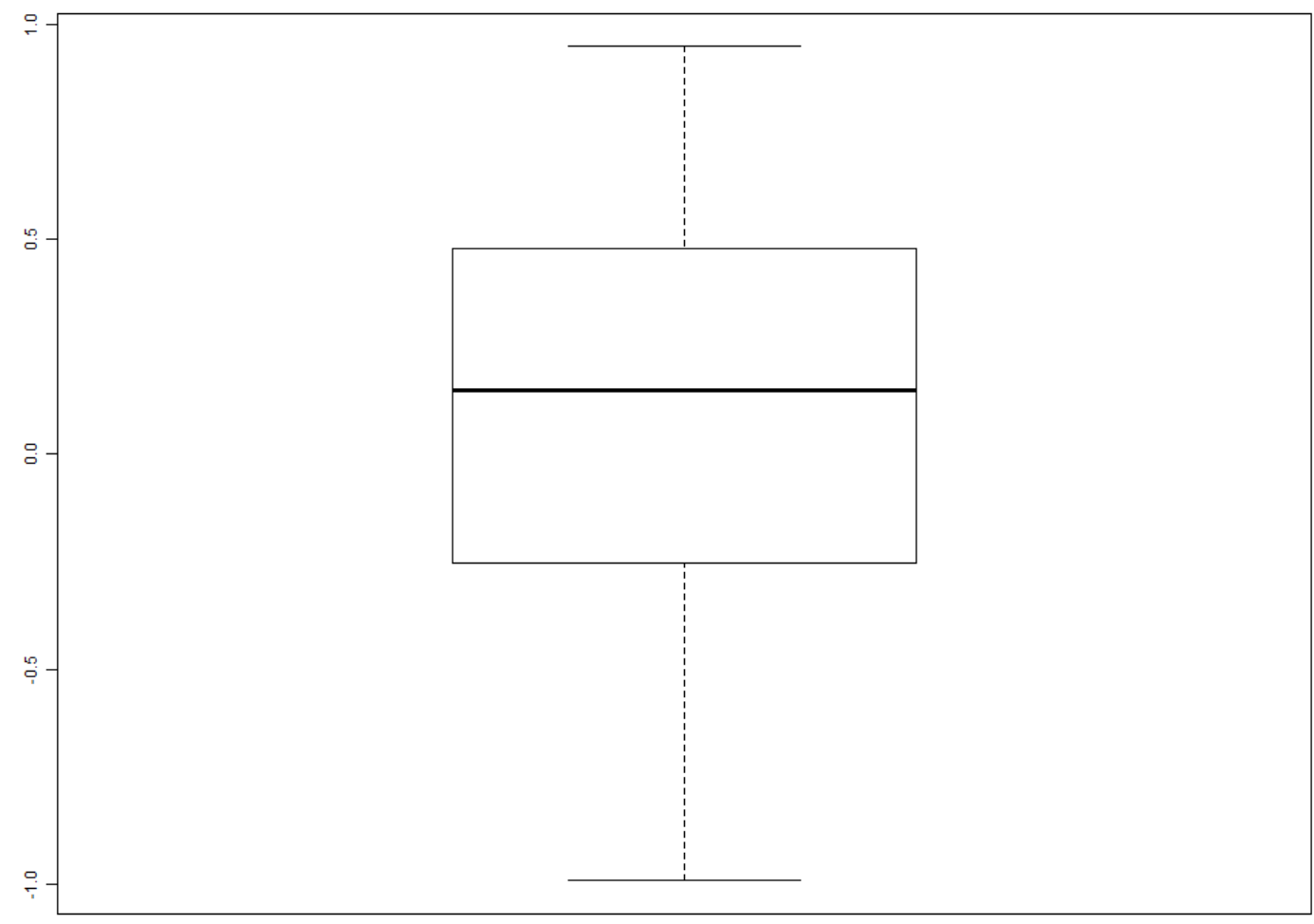

Gráfico 5: Boxplot - Dispersão ideológica - Partidos

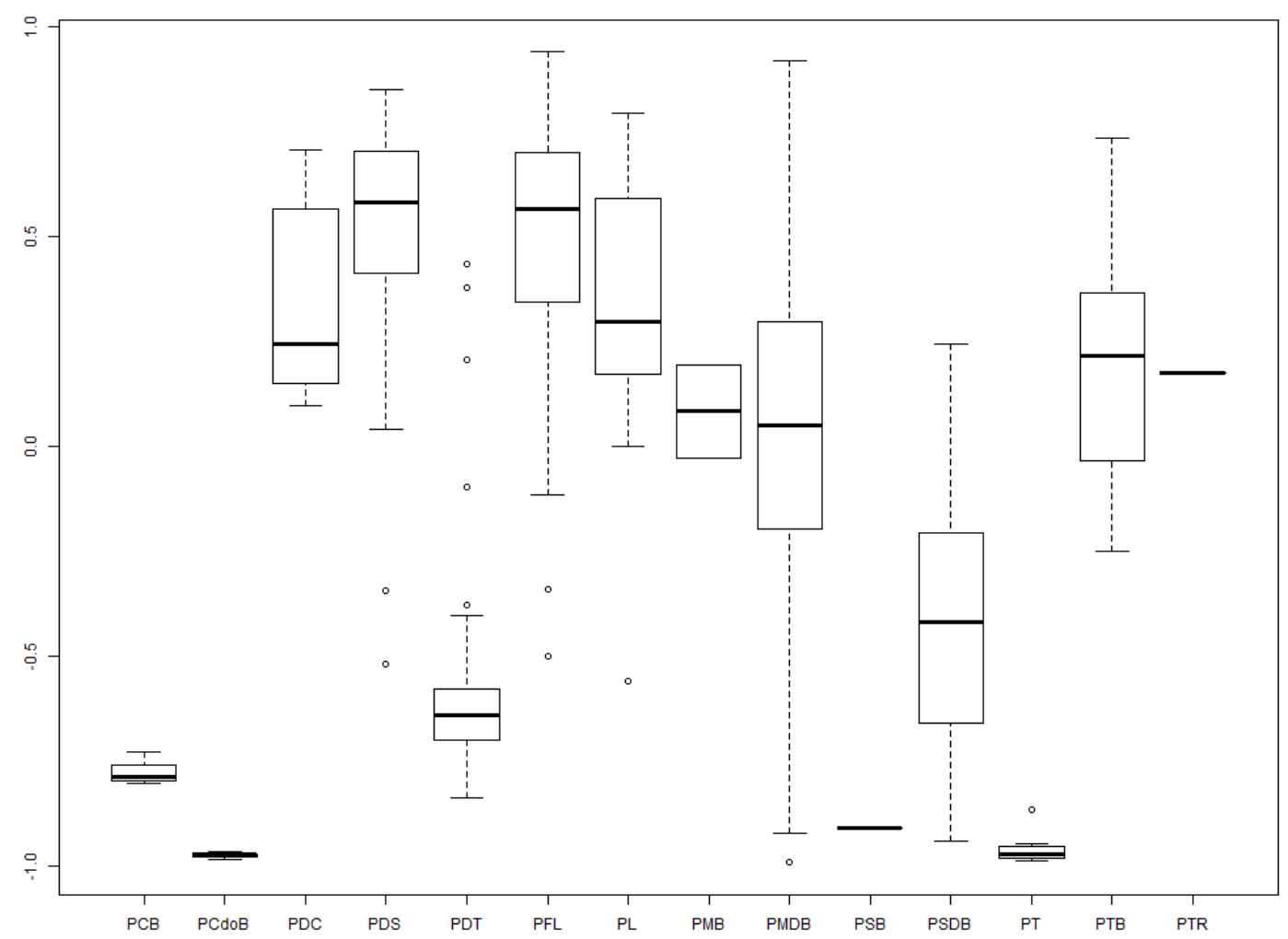


Gráfico 6: Boxplot - Dispersão ideológica - Centrão

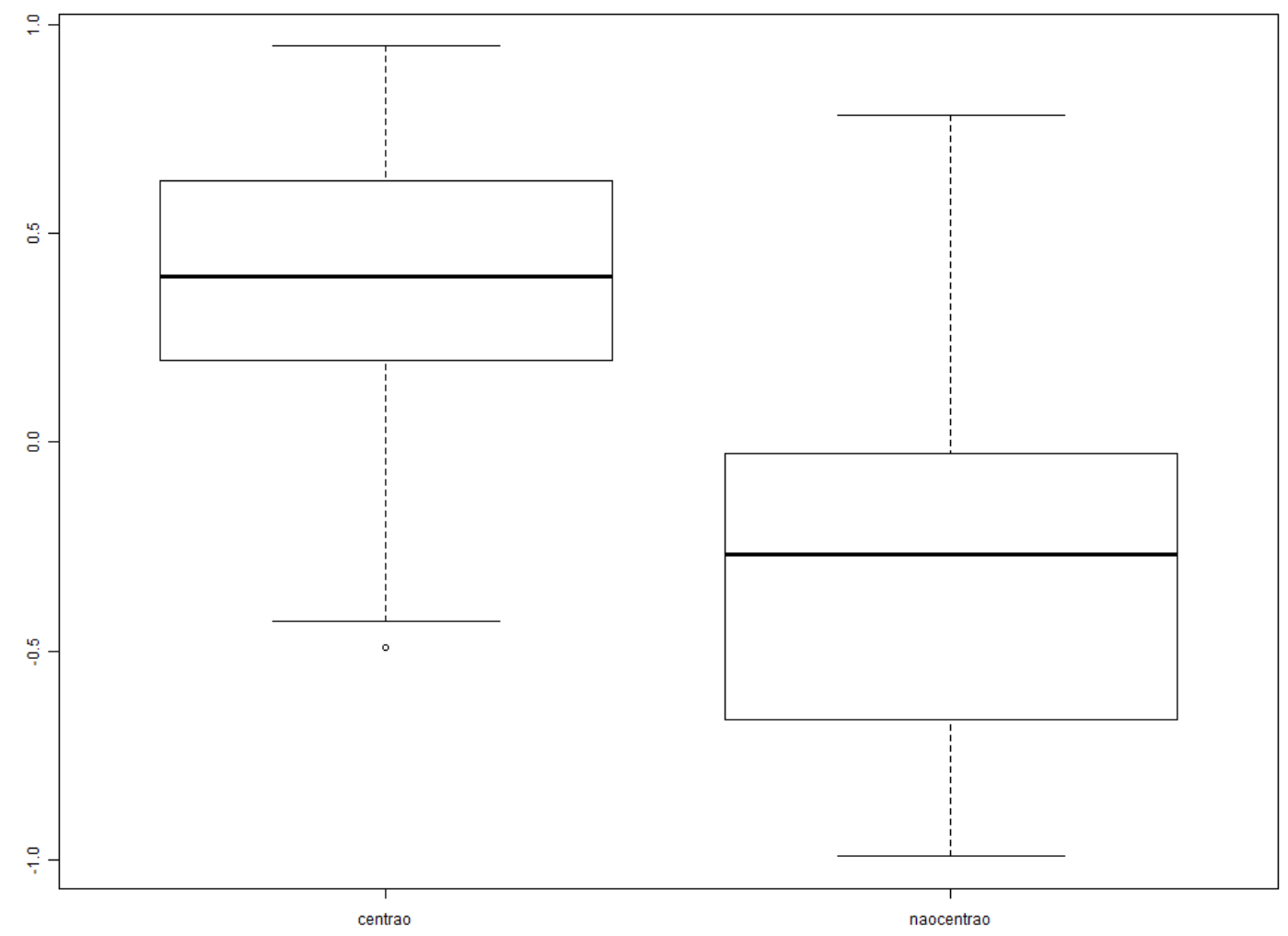

gráfico. O comportamento dos partidos se adequa bem ao esperado. Os partidos de esquerda se concentram bem na parte inferior, a formação do PSDB se justifica pelo seu caráter mais progressista em relação ao seu partido de origem, o PMDB se mostra bastante heterogêneo mesmo com a saída de vários membros para formar o PSDB, e os outros partidos mais concentrados acima no gráfico, no espectro mais conservador, com o PDS e o PFL sendo os mais conservadores. O Centrão também se mostra situado à direita, apesar de existirem constituintes de centro-esquerda no grupo. O inverso se dá com o grupo não-Centrão, concentrado mais à centro-esquerda do espectro ideológico, apesar de existirem direitistas neste grupo. Quando analisamos os parlamentaristas e presidencialistas, notamos que estes últimos se concentram predominantemente na parte superior do gráfico, indicando um viés conservador do grupo, apenas com alguns resíduos presentes no espectro mais progressista (PT e PDT). Os parlamentaristas, no entanto, se concentram na parte inferior, mais próximo da centro-esquerda do espectro ideológico. 
Gráfico 7: Boxplot - Dispersão ideológica - Sistema de governo

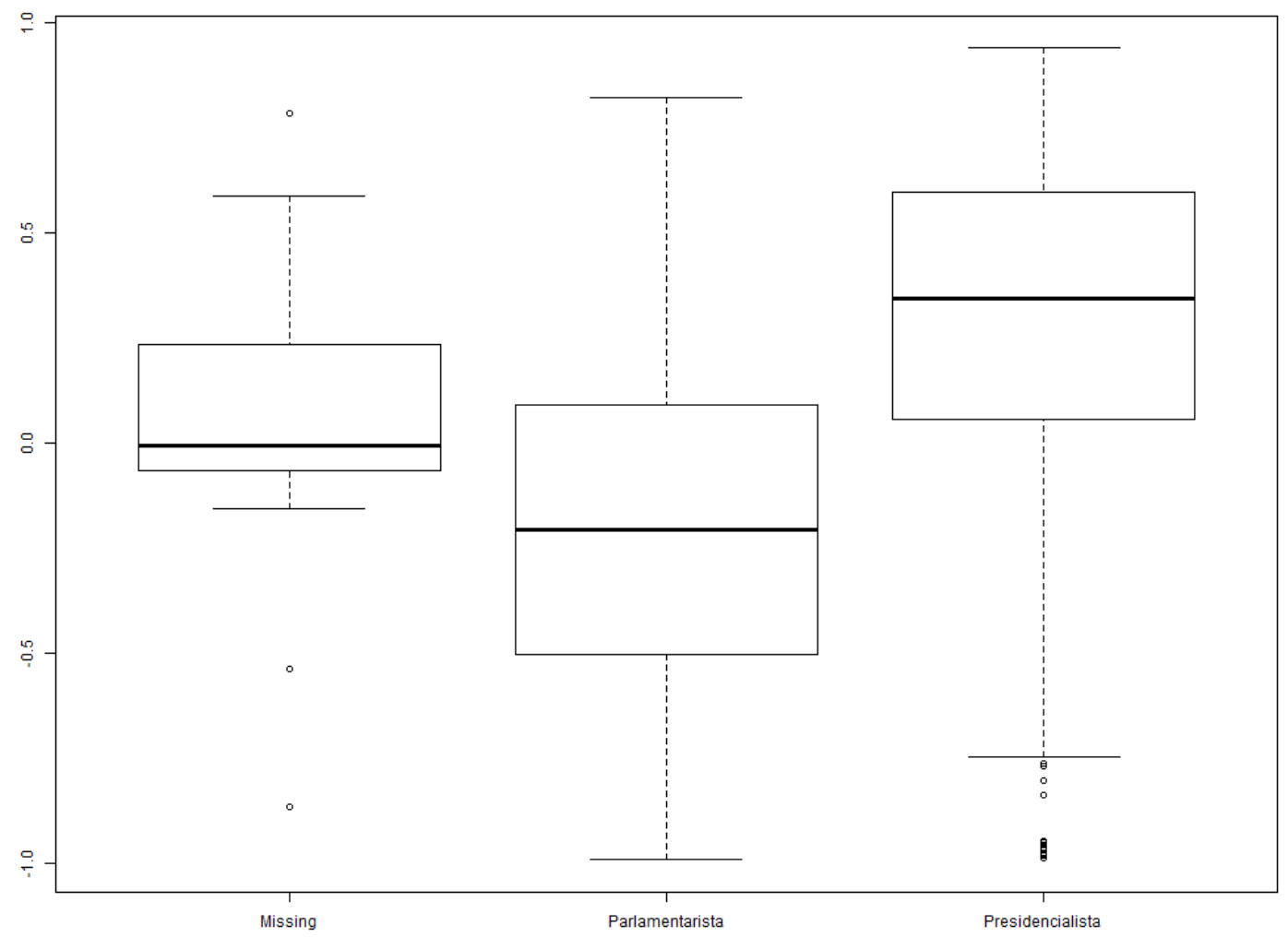

\section{Seção III - A Divisão da Constituinte Frente em Relação ao Sis- tema de Governo}

Por meio das análises empreendidas até aqui, podemos afirmar a existência de quatro grupos no que diz respeito à definição do sistema de governo. O primeiro seria a esquerda presidencialista, representada pelo PT e PDT. Estes dois partidos, que foram unânimes em favor do presidencialismo, possuíam dois candidatos fortes e estavam à frente em pesquisas eleitorais que sondavam intenção de voto para presidente nas eleições seguintes. Brizola e Lula eram favoritos e poucos enxergavam o surgimento de outro político que pudesse fazer frente a estas candidaturas. O segundo grupo seria o de progressistas parlamentaristas, representado pelo PC do B, PCB, PSB e o PSDB. Estes eram partidos que eram unânimes (ou quase) em relação ao parlamentarismo, e, excetuando-se PT e PDT, eram os partidos mais à esquerda e progressistas do plenário. O terceiro grupo seria o PFL, majoritariamente presidencialista. Fundamental na formação e composição do Cen- 
trão, era um dos partidos mais conservadores (se não o mais conservador) da Constituinte e estaria sob influência de Sarney. O quarto grupo seria o mais nebuloso, composto por PMDB, PDS e PTB, partidos que se dividiram quanto à questão do sistema de governo, apesar de serem majoritariamente presidencialistas. O que teria feito que esse grupo se dividisse? Quais seriam os fatores que incentivariam estes constituintes a votarem em um ou outro sistema?

Nossa principal hipótese é de que a divisão no interior desse grupo se explica pela maior ou menor proximidade com o presidente Sarney. Constituintes que estariam mais atrelados ao governo do presidente teriam maior tendência de votar pelo presidencialismo. Motter (1994) explora as acusações feitas na época de que Sarney teria concedido vários canais de rádio e televisão a constituintes em troca de apoio político para conquistar os 5 anos de mandato e o presidencialismo. O governo Sarney teria sido marcado pelo uso explícito e numeroso de concessões de canais, tendo o período conhecido o maior volume de concessões já registrado na história do país. Segundo Baaklini (1993), esse recurso foi fundamental para a formação do Centrão como base de sustentação das ambições políticas de Sarney. Apresentamos a tabela 12 com os partidos dos constituintes que receberam concessões, e a proporção de votos para o presidencialismo:

Nota-se que PFL e PMDB foram os partidos cujos constituintes receberam pouco mais de $90 \%$ das concessões, e $89,5 \%$ dos que receberam concessões votaram em favor da emenda Humberto Lucena, ou seja, a favor do presidencialismo. Porém, como apenas 86 constituintes se enquadram nesse caso, a concessão de canais de TV e rádio não é suficiente para tentar explicar o quarto grupo. Apenas 3 constituintes do PDS receberam concessões e 2 deles votaram para o presidencialismo. O PTB foi exatamente igual ao PDS. PMDB recebeu 32 concessões, sendo que 29 votaram pelo presidencialismo.

Outra forma de medir a influência de Sarney é proposta por Kinzo (1990). A autora cria um índice de "governismo" baseado em 5 votações de plenário que indicariam apoio ao governo Sarney e à situação. A primeira votação seria o preâmbulo do Centrão, que modificava o projeto Cabral com objetivo de restringir o princípio de democracia direta. A segunda votação é sobre os cinco anos de mandato para o presidente Sarney. A terceira 
Tabela 12: Concessões e votação na Emenda Humberto Lucena

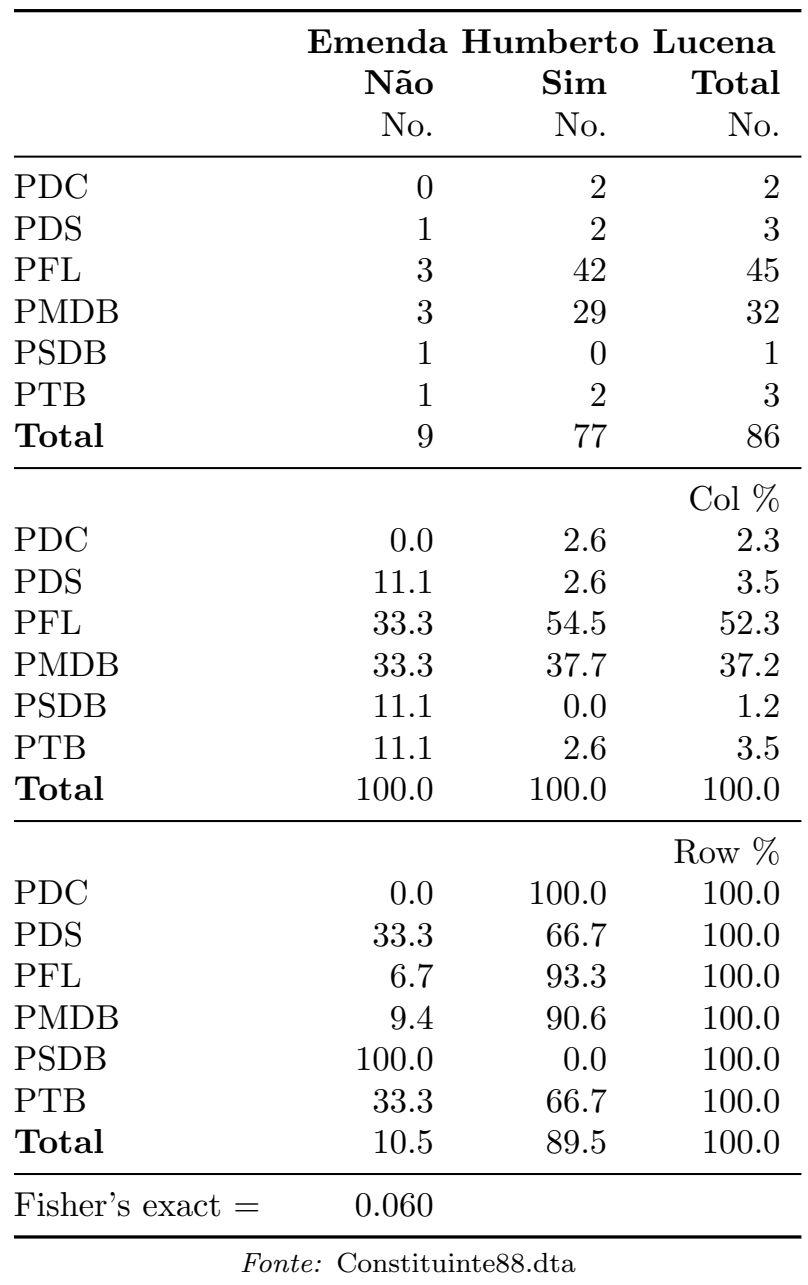

foi sobre cinco anos de mandato para os futuros presidentes, pois estava atrelada à questão do mandato de Sarney. A quarta seria a respeito da suspensão dos dois turnos nas eleições municipais de 1988. A quinta tratava da prorrogação do mandato dos prefeitos, protelando as eleições de 1988. Assim como no trabalho de Kinzo, foram contabilizadas quantas vezes os constituintes votaram a favor, contra ou se abstiveram nestas questões. Um voto a favor soma 1 ponto ao índice, 1 voto contra subtrai um ponto do índice e abstenção mantém a pontuação. Dessa forma, o índice varia de -5 a 5 . A tabela 13 mostra a relação entre o índice e a votação na emenda Humberto Lucena:

O quadro é revelador. Quanto maior o índice, ou seja, quanto maior o governismo, maior o apoio ao presidencialismo. Mas para compreendermos melhor o quarto grupo de partidos, que se dividiram frente a questão do sistema de governo, precisamos observar 
Tabela 13: Governismo e votação na Emenda Humberto Lucena

\begin{tabular}{|c|c|c|c|c|c|c|c|c|c|c|c|c|}
\hline \multirow[b]{2}{*}{ EHL } & \multicolumn{12}{|c|}{ Governismo } \\
\hline & -5 & -4 & -3 & -2 & -1 & 0 & 1 & 2 & 3 & 4 & 5 & $\begin{array}{l}\text { Total } \\
\text { No. }\end{array}$ \\
\hline Abstenção & 1 & 0 & 0 & 0 & 0 & 1 & 0 & 0 & 1 & 0 & 0 & 3 \\
\hline Não & 70 & 29 & 32 & 15 & 21 & 8 & 13 & 7 & 8 & 3 & 6 & 212 \\
\hline Sim & 17 & 9 & 26 & 9 & 17 & 11 & 37 & 37 & 77 & 53 & 51 & 344 \\
\hline Total & 88 & 38 & 58 & 24 & 38 & 20 & 50 & 44 & 86 & 56 & 57 & $\begin{array}{c}559 \\
\%\end{array}$ \\
\hline Abstenção & 33.3 & 0.0 & 0.0 & 0.0 & 0.0 & 33.3 & 0.0 & 0.0 & 33.3 & 0.0 & 0.0 & 100.0 \\
\hline Não & 33.0 & 13.7 & 15.1 & 7.1 & 9.9 & 3.8 & 6.1 & 3.3 & 3.8 & 1.4 & 2.8 & 100.0 \\
\hline Sim & 4.9 & 2.6 & 7.6 & 2.6 & 4.9 & 3.2 & 10.8 & 10.8 & 22.4 & 15.4 & 14.8 & 100.0 \\
\hline Total & 15.7 & 6.8 & 10.4 & 4.3 & 6.8 & 3.6 & 8.9 & 7.9 & 15.4 & 10.0 & 10.2 & $\begin{array}{c}100.0 \\
\%\end{array}$ \\
\hline Abstenção & 1.1 & 0.0 & 0.0 & 0.0 & 0.0 & 5.0 & 0.0 & 0.0 & 1.2 & 0.0 & 0.0 & 0.5 \\
\hline Não & 79.5 & 76.3 & 55.2 & 62.5 & 55.3 & 40.0 & 26.0 & 15.9 & 9.3 & 5.4 & 10.5 & 37.9 \\
\hline Sim & 19.3 & 23.7 & 44.8 & 37.5 & 44.7 & 55.0 & 74.0 & 84.1 & 89.5 & 94.6 & 89.5 & 61.5 \\
\hline Total & 100.0 & 100.0 & 100.0 & 100.0 & 100.0 & 100.0 & 100.0 & 100.0 & 100.0 & 100.0 & 100.0 & 100.0 \\
\hline Pearson $\operatorname{chi} 2(20)=$ & 204.1 & 495 & $\operatorname{Pr}$ & & $=$ & & 0.000 & & & & & \\
\hline
\end{tabular}

Fonte: discursosplenario.dta

este índice relacionado à emenda Humberto Lucena no interior dos partidos. As tabelas 14, 15 e 16 apresentam esses dados com relação ao PMDB, PDS e PTB.

Podemos verificar a relação entre governismo e partidos mais claramente. Novamente encontramos o padrão anterior de que quanto maior o índice de governismo, maior o apoio ao presidencialismo. No PMDB esta tendência é mais clara, devido à maior quantidade de constituintes. No PDS e no PTB as porcentagens ficam um pouco mais confusas pois os partidos são menores, mas a tendência ainda é observada. Assim, podemos dizer que o quarto grupo (PMDB, PDS e PTB) se divide de acordo com a influência governista. Aqueles que tendiam a votar em pautas contra a situação governista votaram pelo parlamentarismo, e os que votavam a favor de pautas governistas votaram pelo presidencialismo. Dessa forma, identificamos como de fato a influência governista de Sarney no comportamento dos constituintes, como foi evidenciado nos discursos de diversos parlamentares, fazendo com que PMDB, PTB e PDS se dividissem frente à questão do sistema de governo.

Através da análise empreendida por meio dos discursos dos constituintes em plenário e da votação da emenda Humberto Lucena, identificamos quatro grupos em relação à 
Tabela 14: Governismo - PMDB

\begin{tabular}{|c|c|c|c|c|c|c|c|c|c|c|c|c|}
\hline EHL & -5 & -4 & -3 & -2 & -1 & 0 & 1 & 2 & 3 & 4 & 5 & $\begin{array}{l}\text { Total } \\
\text { No. }\end{array}$ \\
\hline Abstenção & 0 & 0 & 0 & 0 & 0 & 1 & 0 & 0 & 1 & 0 & 0 & 2 \\
\hline Não & 25 & 19 & 15 & 11 & 8 & 5 & 8 & 4 & 1 & 3 & 1 & 100 \\
\hline Sim & 3 & 3 & 3 & 2 & 11 & 8 & 26 & 17 & 31 & 28 & 20 & 152 \\
\hline Total & 28 & 22 & 18 & 13 & 19 & 14 & 34 & 21 & 33 & 31 & 21 & $\begin{array}{c}254 \\
\%\end{array}$ \\
\hline Abstenção & 0.0 & 0.0 & 0.0 & 0.0 & 0.0 & 50.0 & 0.0 & 0.0 & 50.0 & 0.0 & 0.0 & 100.0 \\
\hline Não & 25.0 & 19.0 & 15.0 & 11.0 & 8.0 & 5.0 & 8.0 & 4.0 & 1.0 & 3.0 & 1.0 & 100.0 \\
\hline Sim & 2.0 & 2.0 & 2.0 & 1.3 & 7.2 & 5.3 & 17.1 & 11.2 & 20.4 & 18.4 & 13.2 & 100.0 \\
\hline Total & $\begin{array}{c}11.0 \\
\%\end{array}$ & $\begin{array}{r}8.7 \\
\%\end{array}$ & $\begin{array}{r}7.1 \\
\%\end{array}$ & $\begin{array}{r}5.1 \\
\%\end{array}$ & $\begin{array}{r}7.5 \\
\%\end{array}$ & $\begin{array}{r}5.5 \\
\%\end{array}$ & $\begin{array}{c}13.4 \\
\%\end{array}$ & $\begin{array}{r}8.3 \\
\%\end{array}$ & $\begin{array}{c}13.0 \\
\%\end{array}$ & $\begin{array}{c}12.2 \\
\%\end{array}$ & $\begin{array}{r}8.3 \\
\%\end{array}$ & $\begin{array}{c}100.0 \\
\%\end{array}$ \\
\hline Abstenção & 0.0 & 0.0 & 0.0 & 0.0 & 0.0 & 7.1 & 0.0 & 0.0 & 3.0 & 0.0 & 0.0 & 0.8 \\
\hline Não & 89.3 & 86.4 & 83.3 & 84.6 & 42.1 & 35.7 & 23.5 & 19.0 & 3.0 & 9.7 & 4.8 & 39.4 \\
\hline Sim & 10.7 & 13.6 & 16.7 & 15.4 & 57.9 & 57.1 & 76.5 & 81.0 & 93.9 & 90.3 & 95.2 & 59.8 \\
\hline Total & 100.0 & 100.0 & 100.0 & 100.0 & 100.0 & 100.0 & 100.0 & 100.0 & 100.0 & 100.0 & 100.0 & 100.0 \\
\hline Pearson chi2 $(20)=$ & 133.2 & 5572 & $\operatorname{Pr}$ & & $=$ & & 0.000 & & & & & \\
\hline
\end{tabular}

Fonte: discursosplenario.dta

Tabela 15: Governismo - PDS

\begin{tabular}{lrrrrrrrrrr}
\hline EHL & $\mathbf{- 5}$ & $\mathbf{- 3}$ & $\mathbf{- 1}$ & $\mathbf{0}$ & $\mathbf{1}$ & $\mathbf{2}$ & $\mathbf{3}$ & $\mathbf{4}$ & $\mathbf{5}$ & $\begin{array}{c}\text { Total } \\
\text { No. }\end{array}$ \\
\hline Não & 2 & 2 & 2 & 0 & 1 & 0 & 4 & 0 & 2 & 13 \\
Sim & 0 & 1 & 0 & 1 & 0 & 5 & 4 & 2 & 6 & 19 \\
Total & 2 & 3 & 2 & 1 & 1 & 5 & 8 & 2 & 8 & 32 \\
& & & & & & & & & & $\%$ \\
Não & 15.4 & 15.4 & 15.4 & 0.0 & 7.7 & 0.0 & 30.8 & 0.0 & 15.4 & 100.0 \\
Sim & 0.0 & 5.3 & 0.0 & 5.3 & 0.0 & 26.3 & 21.1 & 10.5 & 31.6 & 100.0 \\
Total & 6.3 & 9.4 & 6.3 & 3.1 & 3.1 & 15.6 & 25.0 & 6.3 & 25.0 & 100.0 \\
& & & & & & & & & & $\%$ \\
Não & 100.0 & 66.7 & 100.0 & 0.0 & 100.0 & 0.0 & 50.0 & 0.0 & 25.0 & 40.6 \\
Sim & 0.0 & 33.3 & 0.0 & 100.0 & 0.0 & 100.0 & 50.0 & 100.0 & 75.0 & 59.4 \\
Total & 100.0 & 100.0 & 100.0 & 100.0 & 100.0 & 100.0 & 100.0 & 100.0 & 100.0 & 100.0 \\
\hline Fisher's exact $=$ & 0.034 & & & & & & & & & \\
\hline
\end{tabular}

Fonte: discursosplenario.dta 
Tabela 16: Governismo - PTB

\begin{tabular}{lrrrrrrrrrr}
\hline EHL & $\mathbf{4}$ & $\mathbf{- 3}$ & $\mathbf{- 2}$ & $\mathbf{- 1}$ & $\mathbf{1}$ & $\mathbf{2}$ & $\mathbf{3}$ & $\mathbf{4}$ & $\mathbf{5}$ & $\begin{array}{c}\text { Total } \\
\text { No. }\end{array}$ \\
& & & & & & & & & & \\
Não & 0 & 2 & 1 & 2 & 0 & 1 & 0 & 0 & 1 & 7 \\
Sim & 1 & 0 & 0 & 0 & 1 & 1 & 3 & 5 & 1 & 12 \\
Total & 1 & 2 & 1 & 2 & 1 & 2 & 3 & 5 & 2 & 19 \\
& & & & & & & & & & $\%$ \\
Não & 0.0 & 28.6 & 14.3 & 28.6 & 0.0 & 14.3 & 0.0 & 0.0 & 14.3 & 100.0 \\
Sim & 8.3 & 0.0 & 0.0 & 0.0 & 8.3 & 8.3 & 25.0 & 41.7 & 8.3 & 100.0 \\
Total & 5.3 & 10.5 & 5.3 & 10.5 & 5.3 & 10.5 & 15.8 & 26.3 & 10.5 & 100.0 \\
Não & 0.0 & 100.0 & 100.0 & 100.0 & 0.0 & 50.0 & 0.0 & 0.0 & 50.0 & 36.8 \\
Sim & 100.0 & 0.0 & 0.0 & 0.0 & 100.0 & 50.0 & 100.0 & 100.0 & 50.0 & 63.2 \\
Total & 100.0 & 100.0 & 100.0 & 100.0 & 100.0 & 100.0 & 100.0 & 100.0 & 100.0 & 100.0 \\
\hline Fisher's exact $=$ & 0,013 & & & & & & & & & \\
\hline
\end{tabular}

Fonte: discursosplenario.dta

escolha do sistema de governo. O primeiro grupo é o da esquerda presidencialista, cujos partidos possuíam dois fortes candidatos à eleição presidencial seguinte, e que votaram de maneira praticamente unânime em favor do presidencialismo. A principal pauta deste grupo foi a defesa da legitimidade do regime democrático através da participação popular na escolha direta do chefe do executivo. O segundo grupo é o de parlamentaristas progressistas, constituído pelo PC do B, PCB, PSB e PSDB. Foi este grupo que apontou maior preocupação com a trajetória de instabilidade política que o presidencialismo teria ocasionado no país, além de denunciarem a influência de Sarney e das forças armadas na Constituinte. O terceiro grupo é o PFL, grande partido conservador influenciado por Sarney, que foi majoritariamente presidencialista. Seu principal argumento na defesa dessa posição foi a consolidação do sistema partidário através do fortalecimento do legislativo. O quarto e último grupo é composto por PMDB, PDS e PTB, partidos que se dividiram frente à questão do sistema de governo. O fator encontrado para explicar a divisão destes partidos foi o governismo. Constituintes que votavam em pautas governistas votaram no presidencialismo, e os anti-governistas no parlamentarismo. Por ser um grupo mais heterogêneo, nele encontramos argumentações diversas, predominando entre o subgrupo parlamentarista a crítica sobre a influência de Sarney na Constituinte e acusações de que 
PT e PDT seriam presidencialistas por terem candidatos fortes nas próximas eleições presidenciais. 


\section{Conclusão}

Após o longo período do regime militar, a Assembleia Nacional Constituinte de 1987/88 foi convocada com o objetivo de redefinir as instituições democráticas do país. Predominava na época a ideia de que não apenas a ordem legal vigente precisava ser superada, mas também as instituições políticas deveriam ser reformadas. A crise econômica, os escândalos políticos e a falta de legitimidade do sistema político perante a população tornavam urgente a necessidade de uma revisão constitucional. A convocação de uma Assembleia Nacional Constituinte era encarada como condição necessária para que o retorno à democracia fosse completo, deixando no passado os "entulhos" do autoritarismo militar.

Entre os temas em debate, o sistema de governo foi um dos mais polêmicos. No meio acadêmico predominaram os defensores do parlamentarismo. Tanto a literatura internacional na área de política comparada, influenciada pela obra de Juan Linz, como a literatura sobre as instituições políticas brasileiras, liderada principalmente por Bolívar Lamounier, tornaram-se referências dominantes no diagnóstico do funcionamento do presidencialismo. Associado com o sistema proporcional de lista aberta e com o multipartidarismo, o presidencialismo motivaria comportamentos dos atores políticos que dificultariam a consolidação democrática no país. Foi apenas após os trabalhos de Figueiro e Limongi que houve uma defesa mais contundente do sistema presidencialista, através da exposição de dados empíricos sobre como novos arranjos institucionais afetavam o comportamento dos atores políticos no bem sucedido presidencialismo de coalizão.

Se o diagnóstico predominante no período era de que o parlamentarismo seria o melhor sistema de governo para solucionar os problemas políticos que o país enfrentava, por que o presidencialismo acabou por ser escolhido pela maioria da Assembleia Nacional Constituinte? Mesmo com pesquisas indicando que no começo do processo constituinte a maioria dos constituintes preferia o parlamentarismo, foi a emenda Humberto Lucena, que instituía o presidencialismo, que predominou com $61,5 \%$ dos votos. Como podemos explicar esse resultado frente ao cenário pessimista que pairava sobre as instituiçõe políticas nacionais?

Diante da complexidade do processo constituinte, dificilmente poderíamos adotar ape- 
nas uma hipótese para compreendermos este momento de redefinição institucional. As preferências manifestadas pelos constituintes só podem ser apreendidas integrando as três hipóteses apresentadas por Negretto (2009) associadas aos discursos feitos em plenário e aos resultados da votação da emenda Humberto Lucena apresentados. Dessa forma, podemos enquadrar os diversos grupos identificados com relação à definição do sistema de governo em cada uma das hipóteses.

Os constituintes associados a Sarney, tanto do PFL quanto das alas governistas do PMDB, PDS e PTB, corresponderiam à hipótese da influência de forças precedentes. A influência que Sarney e os militares exerceram na Constituinte se expressou através do comportamento destes constituintes conservadores. A transição democrática teve fortes elementos de continuidade com o regime militar. A Assembleia Nacional Constituinte foi convocada e eleita pelas mesmas regras eleitorais e sistema partidário anteriores. Como afirma Elster (1995; 2009), constituintes não são autocriadas. É uma autoridade externa que toma a decisão de convocá-las e de como seus membros devem ser eleitos ou selecionados. Segundo o autor, é natural que esta autoridade tente influenciar a definição dos procedimentos a serem adotados pela Assembleia bem como suas decisões substantivas, impondo-se como uma subautoridade. Dessa forma, o antigo regime e as forças políticas precedentes quase que por definição constituem parte do problema que uma Constituinte deve encarar e resolver. Não foi por acaso que no momento da convocação da Assembleia Nacional Constituinte houve um intenso debate se ela deveria ser exclusiva ou congressual.

Sarney conseguiu exercer grande pressão no processo constituinte, e se valeu de sua influência para fazer com que o presidencialismo fosse aprovado, juntamente com um mandato de 5 anos. Ao defender seus interesses, pode ser enquadrado no que Elster (1995) chama de interesse institucional, que costuma ter uma linha tênue com o interesse pessoal. Este tipo de interesse seria frequentemente tido por presidentes para manterse com maiores poderes no cargo. Negretto (2013) chega a afirmar que processos de redefinição institucional pode ser influenciado de forma significante caso o partido que controla a Presidência da República possui poder para fazer aprovar reformas que lhe interessa. Dessa forma, Sarney fez uso da distribuição de recursos para angariar apoio dos 
conservadores, interessados na permanência dos instrumentos de clientelismo e fisiologismo que já conheciam. Além disso, os militares também apoiariam Sarney pois enxergavam no presidencialismo uma forma de manter certa influência no sistema político através de seu papel moderador.

É inegável que o ambiente constituinte também propicia o exercício do debate e a defesa de argumentos normativos menos calcados em interesses institucionais e nas forças que defendem o status quo. Foi nesse contexto que o grupo de parlamentaristas progressistas, constituído pelo PC do B, PCB, PSB e PSDB, atuou e defendeu seu ponto de vista. Esse grupo se enquadra assim na hipótese da imparcialidade, na qual os atores políticos fazem suas escolhas institucionais através de suas preferências normativas, baseados em benefícios coletivos como governabilidade e legitimidade. Neste grupo, o cálculo estratégico de curto prazo não se sobrepôs à suas preferências normativas sobre o tema, principalemente para os parlamentaristas que compunham o PMDB. Segundo Elster (1998), o contexto específico de uma assembléia constituinte favorece a deliberação, influenciando as propostas e argumentos que podem ser feitos de forma mais normativa, e menos sustentados por interesses particulares. É neste momento que atores políticos ganham grau de liberdade para pensar nas escolhas institucionais de longo prazo, projetando desenhos institucionais com base em ideias e valores, e não apenas interesses de curto prazo.

O grupo de constituintes que faziam parte do PT e PDT correspondem à hipótese relacionada ao interesse próprio e partidário. Com a possibilidade clara de chegarem à Presidência da República, o comportamento destes partidos teria sido orientado pela força dos interesses imediatos e organizados. O pragmatismo destes partidos é bem ilustrado no argumento de Elster (1995) e Negretto (2013), quando afirmam que interesses de partidos políticos frequentemente são decisivos na definição de instituições da máquina de governo. Tais membros possuem interesses partidários na adoção de instituições específicas que os deixem em vantagem na competição pelo poder. $\mathrm{O}$ conflito entre o interesse partidário e um interesse normativo, associado à escolha pelo presidencialismo, expunha com frequência os dois partidos a críticas. Tal comportamento é ainda mais saliente em relação ao PT, uma vez que alguns de seus membros chegaram a defender normativamente 
o parlamentarismo não só durante a Constituinte, mas antes e depois dela (como aconteceu no plebiscito de 1993).

Cabe notar que tanto em 1987/88 quanto em 1961/63, tanto progressistas quanto conservadores tiveram razões próprias para apoiar o presidencialismo. Mas a maior diferença entre os dois contextos foi que a Assembleia Nacional Constituinte favoreceu a deliberação e o surgimento de argumentos normativos, principalmente em torno do parlamentarismo. De qualquer maneira, o ambiente proporcionado por uma constituinte não é capaz de isolar e promover apenas uma forma de atuação política, com vistas ao redesenho institucional. A experiência brasileira de 1988 só se torna inteligível se combinarmos analiticamente os fortes elementos de continuidade, os interesses partidários de curto prazo e as ideias normativas defendidas no debate constitucional. 


\section{Referências}

Abranches, Sérgio. 1988. "Presidencialismo de coalizão: o dilema institucional brasileiro." Dados 31(1):5-38.

Araújo, Cícero. 2009. O processo constituinte: sociedade civil e povo na transição. In $A s$ múltiplas faces da Constituição cidadã, ed. Jefferson O. Goulart. São Paulo: Cultura Acadêmica pp. 13-25.

Baaklini, Abdo I. 1993. O Congresso e o Sistema Político do Brasil. Paz e Terra.

Beland, Daniel e Robert Henry Cox. 2011. Ideas and Politics in Social Science Research. Oxford University Press.

Benoit, Kenneth. 2004. "Models of electoral system change." Electoral Studies: An international Journal 23(3):363-389.

Benoit, Kenneth. 2007. "Electoral laws as political consequences: explaining the origins and change of electoral institutions." Annu. Rev. Polit. Sci. 10:363-390.

Cheibub, José Antonio. 2007. Presidentialism, parliamentarism, and democracy. Cambridge University Press.

DIAP. 1988. Quem foi quem na Constituinte: nas questões de interesse dos trabalhadores. São Paulo: Cortez/Oboré.

Elster, Jon. 1983. Explaining technical change: A case study in the philosophy of science. Cambridge University Press.

Elster, Jon. 1993. "Constitution-making in Eastern Europe: Rebuilding the boat in the open sea." Public administration 71(1):169-217.

Elster, Jon. 1994. The Impact of Constitutions on Economic Performance. In Proceedings of the World Bank Annual Conference on Development Economics. Vol. 6 World Bank Publications pp. 209-226. 
Elster, Jon. 1995. "Forces and mechanisms in the constitution-making process." Duke Law Journal 45(2):364-396.

Elster, Jon. 1998. Deliberation and Constitution Making. In Deliberative Democracy, ed. Jon Elster. Cambridge: Cambridge University Press pp. 97-122.

Elster, Jon. 2008. "The optimal design of a Constituent Assembly." Manuscrito.

Elster, Jon. 2009. "Ulisses liberto: estudos sobre racionalidade, pré-compromisso e restrições." São Paulo: UNESP.

Ferreira, Pedro Fernando de Almeida Nery. 2013. Como Decidem os Ministros do STF. Master's thesis Economia - UnB.

Figueiredo, Argelina. 1993. Democracia ou reformas?: Alternativas democráticas à crise política: 1961-1964. Paz e Terra.

Figueiredo, Argelina e Fernando Limongi. 1994. "O processo legislativo ea produção legal no congresso pós-constituinte." Novos Estudos Cebrap 38:3-38.

Figueiredo, Argelina e Fernando Limongi. 1995. "Mudança constitucional, desempenho do Legislativo e consolidação institucional." Revista Brasileira de Ciências Sociais 10(29):175-200.

Figueiredo, Argelina e Fernando Limongi. 1997. "O Congresso e as medidas provisórias: abdicação ou delegação?" Novos Estudos Cebrap 47:127-154.

Figueiredo, Argelina e Fernando Limongi. 1998. "Bases institucionais do presidencialismo de coalizão." Lua Nova: Revista de cultura de politica 44:81.

Figueiredo, Argelina e Fernando Limongi. 2007. Instituições Políticas e Governabilidade. Desempenho do governo e apoio legislativo na democracia brasileira. In A democracia brasileira: balanço e perspectivas para o século 21, ed. Carlos R. Melo e Manuel A Saez. Editora UFMG pp. 147-198. 
Fleischer, David. 1996. "Political corruption in Brazil." Crime, Law and Social Change 25(4):297-321.

Freitas, Rafael, Samuel Moura e Danilo Medeiros. 2009. Procurando o Centrão: Direita e Esquerda na Assembléia Nacional Constituinte 1987-88. In A Constituição de 1988: passado e futuro, ed. Maria Alice Rezende de Araújo, Cícero Araújo e Júlio Assis Simões. São Paulo: Anpocs / FFord / Ed. Hucitec pp. 101-135.

Ginsburg, Tom, Zachary Elkins e Justin Blount. 2009. "Does the Process of ConstitutionMaking Matter?" Annual Review of Law and Social Science 5:201-223.

Gomes, Sandra. 2006. "O Impacto das Regras de Organização do Processo Legislativo no Comportamento dos Parlamentares: um estudo de caso da Assembléia Nacional Constituinte (1987-1988)." Dados 49(1):193-224.

Hall, Peter A. e Rosemary C.R. Taylor. 1996. "Political Science and the Three New Institutionalisms." Political studies 44(5):936-957.

Kinzo, Maria D’Alva G. 1990. O quadro partidário e a Constituinte. In De Geisel a Collor: o Balanço da Transição, ed. Bolívar Lamounier. São Paulo: Editora Sumaré.

Lamounier, Bolívar. 1990. Brasil: Rumo ao Parlamentarismo? In A opção parlamentarista, ed. Bolívar Lamounier. São Paulo: Sumaré/Idesp.

Lamounier, Bolívar. 1991. "Parlamentarismo, Sistema Eleitoral e Governabilidade." Nova Economia 2(2):9-25.

Lamounier, Bolívar. 1992. Estrutura institucional e governabilidade na década de 90. In O Brasil e as reformas políticas, ed. João Paulo dos Reis Velloso. Rio de Janeiro: José Olympio.

Lamounier, Bolívar e Dieter Nohlen. 1993. Presidencialismo ou Parlamentarismo. São Paulo: IDESP.

Leoni, Eduardo. 2002. "Ideologia, Democracia e Comportamento Parlamentar: A Camara dos Deputados (1991-1998)." Dados 45(3). 
Lijphart, Arend. 2003. Modelos de democracia: desempenho e padrões de governo em 36 países. Civilização brasileira.

Limongi, Fernando. 2008. O Poder Executivo na Constituição de 1988. In A Constituição de 1988 na vida brasileira, ed. Ruben George Oliven, Marcelo Ridenti e Gildo Marçal Brandão. Editora Hucitec pp. 23-56.

Limongi, Fernando e Argelina Figueiredo. 2005. "Processo orçamentário e comportamento legislativo: emendas individuais, apoio ao Executivo e programas de governo." Dados 48(004):737-776.

Linz, Juan. 1991. "Presidencialismo ou Parlamentarismo: faz alguma diferença?" A opção parlamentarista, SP: Editora Sumaré.

Lopes, Júlio A. V. 2008. "O processo Constituinte do Presidencialismo de 1988.".

Madeira, Rafael Machado. 2011. "A atuação de ex-arenistas e ex-emedebistas na assembleia nacional constituinte." Revista Brasileira de Ciências Sociais 26(77):189-204.

Mainwaring, Scott. 1991. "Políticos, partidos e sistemas eleitorais." Novos Estudos Cebrap $29: 34-58$.

Mainwaring, Scott. 1993. "Democracia presidencialista multipartidária: o caso do Brasil." Lua Nova: Revista de Cultura e Política (28-29):21-74.

Marcelino, Danilo, Sérgio Braga e Luiz Domingos Costa. 2010. "Parlamentares na Constituinte de 1987/88: uma contribuição à solução do "enigma do Centrão"." Revista Política Hoje 18(2):239-279.

Medeiros, Danilo Buscatto. 2013. Organizando maiorias, agregando preferências: a Assembleia Nacional Constituinte de 1987-88. Master's thesis FFLCH - USP.

Motter, Paulino. 1994. "O uso político das concessões das emissoras de rádio e televisão no governo Sarney." Comunicação \& Política 1(1):89-116. 
Negretto, Gabriel L. 2006. "Choosing How to Choose Presidents: Parties, Military Rulers, and Presidential Elections in Latin America." Journal of Politics 68(2):421-433.

Negretto, Gabriel L. 2009. "Political Parties and Institutional Design: Explaining Constitutional Choice in Latin America." British Journal of Political Science 39(01):117-139.

Negretto, Gabriel L. 2013. Making Constitutions: Presidents, Parties, and Institutional Choice in Latin America. Cambridge University Press.

Nobre, Marcos. 2008. "Indeterminação e estabilidade: os 20 anos da Constituição Federal e as tarefas da pesquisa em direito." Novos Estudos-CEBRAP (82):97-106.

Pierson, Paul. 2004. Politics in Time: History, institutions, and social analysis. Princeton University Press.

Pilatti, Adriano. 2008. A Constituinte de 1987-1988: progressistas, conservadores, ordem econômica e regras do jogo. Editora PUC-Rio.

Poole, Keith T e Howard Rosenthal. 1985. "A spatial model for legislative roll call analysis." American Journal of Political Science pp. 357-384.

Poole, Keith T e Howard Rosenthal. 1991. "Patterns of congressional voting." American Journal of Political Science pp. 228-278.

Praça, Sérgio e Simone Diniz. 2008. As duas faces da Constituição de 1988. In Vinte anos de Constituição, ed. Sérgio Praça e Simone Diniz. São Paulo: Ed. Paulus pp. 7-18.

Przeworski, Adam. 1994. Democracia e Mercado: reformas políticas e econômicas na Europa Oriental e na América Latina. Rio de Janeiro: Relume-Dumará.

Rodrigues, Leôncio Martins, Renato Lessa, Wanderley Guilherme dos Santos, Roberto Mangabeira Unger, Gilberto Felisberto Vasconcellos, Joel Rufino dos Santos, Vladimir Palmeira, Ivan Cavalcanti Proença e Leonel Brizola. 1993. Em Defesa do Presidencialismo. Espaço e Tempo. 
Schmidt, Vivian A. 2010. "Taking ideas and discourse seriously: explaining change through discursive institutionalism as the fourth 'new institutionalism'." European Political Science Review 2(01):1-25.

Silva, José Afonso da. 1990. "Presidencialismo e parlamentarismo no Brasil." Revista de Ciência Politica 33:9-33.

Simoni Junior, Sérgio, Patrick C. Silva e Rafael de Souza. 2009. Sistema Eleitoral na ANC 1987-88: a manutenção da representação proporcional. In A Constituição de 1988 - Passado e Futuro, ed. Maria Alice Rezende de Carvalho, Cícero Araújo e Júlio Assis Simões. Hucitec pp. 136-168.

Souza, Celina. 2001. "Federalismo e descentralização na Constituição de 1988: processo decisório, conflitos e alianças." Dados-Revista de Ciências Sociais 44(3):513-560.

Souza, Márcia T. de. 2003. "O processo decisório na Constituição de 1988: práticas institucionais." Lua Nova: revista de cultura e política (58):37-59.

Stepan, Alfred e Cindy Skach. 1993. "Quadros metainstitucionais e consolidação democrática." Presidencialismo ou parlamentarismo. São Paulo: Loyola pp. 218-235.

Zarevucha, Jorge. 1994. "Relações civil-militares no primeiro governo da transição brasileira: uma democracia tutelada." Revista Brasileira de Ciências Sociais 9(26):162-178.

Zucco Jr, Cesar. 2009. "Ideology or What? Legislative Behavior in Multiparty Presidential Settings." The Journal of Politics 71(3):1076-1092. 